\title{
(+)-Saxitoxin: A First and Second Generation Stereoselective Synthesis
}

\section{Supplementary Information}

(24 pages)

James J. Fleming, Matthew D. McReynolds, and J. Du Bois*

Department of Chemistry

Stanford University

Stanford, CA 94305-5080 
General. All reagents were obtained commercially unless otherwise noted. Reactions were performed using ovendried glassware under an atmosphere of nitrogen. Air- and moisture sensitive liquids and solutions were transferred via syringe or stainless steel cannula. Organic solutions were concentrated under reduced pressure (ca. $20 \mathrm{~mm} \mathrm{Hg}$ ) by rotary evaporation. Dichloromethane, tetrahydrofuran (THF), acetonitrile $(\mathrm{MeCN})$ and $N, N$-dimethylformamide (DMF) were passed through two columns of activated alumina immediately prior to use. Hexamethyldisilazane was distilled from $\mathrm{CaH}_{2}$ and trifluoroacetic acid was distilled from $\mathrm{MgSO}_{4}$. $N$-[1-Chloro-1-methylsulfanylmethylidene]4-methoxybenzenesulfonamide was prepared according to the procedure of Neidlain and Haussmann ${ }^{1}$ and $N$ dichloromethylene-4-methoxybenzenesulfonamide was prepared according to the procedure of Gompper., ${ }^{2,3}$ Boron tris(trifluoroacetate) was prepared as a $0.5 \mathrm{M}$ solution in trifluoroacetic acid as described by Bauer ${ }^{4}$ and stored in a Schlenk flask at $25{ }^{\circ} \mathrm{C}$. Chromatographic purification of products was accomplished using forced flow chromatography on Silicycle silica gel $60(40-63 \mu \mathrm{m})$. Thin layer chromatography was performed on EM Science silica gel $60 \mathrm{~F}_{254}$ plates $(250 \mu \mathrm{m})$. Visualization of the developed chromatogram was accomplished by fluorescence quenching and by staining with ethanolic anisaldehyde, aqueous potassium permanganate, or aqueous ceric ammonium molybdate (CAM) solution. High pressure liquid chromatography (HPLC) purification was performed using a Waters instrument with either a Novapac $\mathrm{C}_{18}, 7.8$ x $300 \mathrm{~mm}, 6 \mu \mathrm{m}$ column using $\mathrm{MeCN} / \mathrm{H}_{2} \mathrm{O}$ as eluent with $0.1 \% \mathrm{CF}_{3} \mathrm{CO}_{2} \mathrm{H}$ buffer or $10 \mathrm{mM} \mathrm{C}_{3} \mathrm{~F}_{7} \mathrm{COOH}$ (as indicated).

Nuclear magnetic resonance (NMR) spectra were acquired on a Varian Inova spectrometer operating at 400, 500, or 600 and 100,125 , or $150 \mathrm{MHz}$ for ${ }^{1} \mathrm{H}$ and ${ }^{13} \mathrm{C}$, respectively, and are referenced internally according to residual solvent signals. Data for ${ }^{1} \mathrm{H}$ NMR are recorded as follows: chemical shift $(\delta, \mathrm{ppm})$, multiplicity (s, singlet; $d$, doublet; t, triplet; q, quartet; quint, quintet; m, multiplet; br, broad), integration, coupling constant (Hz). Data for ${ }^{13} \mathrm{C}$ NMR are reported in terms of chemical shift $(\delta$, ppm). Infrared (IR) spectra were recorded as either thin films using $\mathrm{NaCl}$ plates or as $\mathrm{KBr}$ pellets on a Thermo-Nicolet $300 \mathrm{FT}$-IR spectrometer and are reported in frequency of absorption. Optical rotation data were obtained from samples loaded into a $50 \mathrm{~mm}$ cell on a Jasco DIP-1000 digital polarimeter operating at the Na D-line. High resolution mass spectra were obtained from the Vincent Coates Foundation Mass Spectrometry Laboratory at Stanford University.

\section{Experimental protocols and characterization data:}

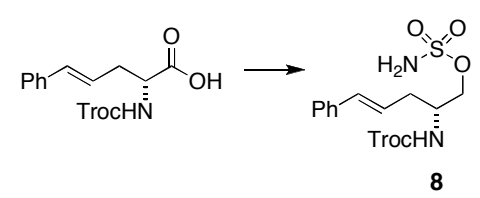

To a solution of $(R)$-2-( $N$-trichloroethoxycarbonyl)-5-phenyl-4-pentenoic acid ${ }^{5}(6.43 \mathrm{~g}, 17.5 \mathrm{mmol})$ in $18 \mathrm{~mL}$ of DME cooled to $-10^{\circ} \mathrm{C}$ was added $N$-methylmorpholine $(2.0 \mathrm{~mL}, 17.9 \mathrm{mmol}, 1.02$ equiv) and isobutylchloroformate ( $2.3 \mathrm{~mL}, 17.9 \mathrm{mmol}, 1.02$ equiv). The mixture was stirred for $5 \mathrm{~min}$ at $-10^{\circ} \mathrm{C}$ during which time a white precipitate formed. The slurry was filtered through a small pad of Celite, washing the flask and filter cake with $18 \mathrm{~mL}$ of DME. The combined filtrates were cooled to $-10^{\circ} \mathrm{C}$ and to this solution was added dropwise a solution of $\mathrm{NaBH}_{4}(995 \mathrm{mg}$, $26.3 \mathrm{mmol}, 1.5$ equiv) in $10 \mathrm{~mL}$ of $\mathrm{H}_{2} \mathrm{O}$. After stirring the contents for $15 \mathrm{~min}$ at $-10{ }^{\circ} \mathrm{C}, 50 \mathrm{~mL}$ of $\mathrm{H}_{2} \mathrm{O}$ was added and the mixture was transferred to a separatory funnel containing $150 \mathrm{~mL}$ of EtOAc. The organic phase was collected and the aqueous layer was extracted with $3 \times 50 \mathrm{~mL}$ of EtOAc. The combined organic extracts were dried over $\mathrm{Na}_{2} \mathrm{SO}_{4}$, filtered, and concentrated under reduced pressure. Purification of the oily residue by chromatography on silica gel (2:1 hexanes/EtOAc) afforded the corresponding $1^{\circ}$ alcohol as a colorless oil $(3.97 \mathrm{~g}, 64 \%)$ : $\mathrm{TLC} \mathrm{R}_{f}=$ 0.23 (2:1 hexanes/EtOAc); ${ }^{1} \mathrm{H}$ NMR $\left(\mathrm{CDCl}_{3}, 400 \mathrm{MHz}\right) \delta$ 7.37-7.18 (m, 5H), 6.49 (d, $\left.1 \mathrm{H}, J=15.9 \mathrm{~Hz}\right), 6.18$ (ddd, $1 \mathrm{H}, J=14.8,7.3,7.3 \mathrm{~Hz}), 5.26(\mathrm{~d}, 1 \mathrm{H}, J=7.2 \mathrm{~Hz}), 4.70(\mathrm{~d}, 1 \mathrm{H}, J=12.1 \mathrm{~Hz}), 4.73(\mathrm{~d}, 1 \mathrm{H}, J=12.1 \mathrm{~Hz}), 3.94-3.84$ (m, 1H), $3.79(\mathrm{dd}, 1 \mathrm{H}, J=11.0,4.0 \mathrm{~Hz}), 3.73(\mathrm{dd}, 1 \mathrm{H}, J=11.0,4.9 \mathrm{~Hz}), 2.60-2.44(\mathrm{~m}, 2 \mathrm{H}), 1.96(\mathrm{br} \mathrm{s}, 1 \mathrm{H}) \mathrm{ppm}$.

To a flask containing $\mathrm{ClSO}_{2} \mathrm{NCO}\left(2.7 \mathrm{~mL}, 31.5 \mathrm{mmol}, 3.0\right.$ equiv) in $15 \mathrm{~mL}$ of ice-cold $\mathrm{CH}_{2} \mathrm{Cl}_{2}$ was added via addition funnel a solution of $\mathrm{HCO}_{2} \mathrm{H}\left(1.2 \mathrm{~mL}, 31.5,3.0\right.$ equiv) in $15 \mathrm{~mL}$ of $\mathrm{CH}_{2} \mathrm{Cl}_{2}$. Vigorous gas evolution was witnessed immediately. The solution was warmed from $0^{\circ}$ to $23{ }^{\circ} \mathrm{C}$ and stirred for $10 \mathrm{~h}$. Following this period, the resulting white suspension was cooled to $-10^{\circ} \mathrm{C}$ and a solution of $1^{\circ}$ alcohol $(3.70 \mathrm{~g}, 10.5 \mathrm{mmol}), \mathrm{Et}_{3} \mathrm{~N}(5.1 \mathrm{~mL}$, 
$36.7 \mathrm{mmol}, 3.5$ equiv) and DMAP (64 mg, $525 \mu$ mol, 0.05 equiv) in $40 \mathrm{~mL}$ of $\mathrm{CH}_{2} \mathrm{Cl}_{2}$ was added via cannula. An additional $10 \mathrm{~mL}$ of $\mathrm{CH}_{2} \mathrm{Cl}_{2}$ was used to ensure quantitative transfer of the alcohol. The homogeneous solution was warmed to $23{ }^{\circ} \mathrm{C}$ and stirred for $30 \mathrm{~min}$. The reaction mixture was then concentrated under reduced pressure to $\sim 1 / 3$ the original volume and poured into a separatory funnel containing $300 \mathrm{~mL}$ of EtOAc and $150 \mathrm{~mL}$ of aqueous $\mathrm{NaH}_{2} \mathrm{PO}_{4} / \mathrm{Na}_{2} \mathrm{HPO}_{4}$ buffer ( $\mathrm{pH}$ 7.5). The organic phase was collected and the aqueous layer was extracted with $3 \mathrm{x}$ $50 \mathrm{~mL}$ of EtOAc. The combined organic extracts were dried over $\mathrm{Na}_{2} \mathrm{SO}_{4}$, filtered, and concentrated under reduced pressure to an oily residue. Purification by chromatography on silica gel (2:1 hexanes/EtOAc) afforded sulfamate ester 8 as a colorless oil $(3.60 \mathrm{~g}, 79 \%)$ : TLC $\mathrm{R}_{f}=0.28\left(2: 1\right.$ hexanes/EtOAc); ${ }^{1} \mathrm{H}$ NMR $\left(\mathrm{CDCl}_{3}, 500 \mathrm{MHz}\right) \delta 7.36-$ $7.22(\mathrm{~m}, 5 \mathrm{H}), 6.52(\mathrm{~d}, 1 \mathrm{H}, J=15.8 \mathrm{~Hz}), 6.14(\mathrm{ddd}, 1 \mathrm{H}, J=15.6,7.3,7.3 \mathrm{~Hz}), 5.22(\mathrm{~d}, 1 \mathrm{H}, J=8.8 \mathrm{~Hz}), 4.93(\mathrm{~s}, 2 \mathrm{H})$, $4.73(\mathrm{~d}, 1 \mathrm{H}, J=12.1 \mathrm{~Hz}), 4.71(\mathrm{~d}, 1 \mathrm{H}, J=12.1 \mathrm{~Hz}), 4.35(\mathrm{dd}, 1 \mathrm{H}, J=10.3,4.0 \mathrm{~Hz}), 4.26(\mathrm{dd}, 1 \mathrm{H}, J=10.4,4.8 \mathrm{~Hz})$, 4.19-4.10 (m, 1H), 2.62-2.50 (m, 2H) ppm; ${ }^{13} \mathrm{C}$ NMR $\left(\mathrm{CDCl}_{3}, 100 \mathrm{MHz}\right) \delta 154.5,136.6,133.9,128.5,127.6,126.1$, 123.9, 95.3, 74.4, 71.1, 50.2, 34.4 ppm; IR (thin film) v 3373 (br), 3028, 2957, 1717, 1527, 1369, $1183 \mathrm{~cm}^{-1}$; HRMS $\left(\mathrm{ES}^{+}\right)$calcd for $\mathrm{C}_{14} \mathrm{H}_{17} \mathrm{Cl}_{3} \mathrm{~N}_{2} \mathrm{O}_{5} \mathrm{~S} 429.9924$ found $452.9824\left(\mathrm{MNa}^{+}\right)$.

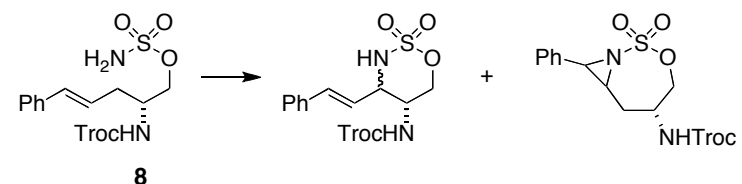

To a stirred suspension of sulfamate ester $8(3.37 \mathrm{~g}, 7.81 \mathrm{mmol})$ and $\mathrm{MgO}$ (724 mg, $18.0 \mathrm{mmol}, 2.3 \mathrm{equiv})$ in $55 \mathrm{~mL}$ of $\mathrm{CH}_{2} \mathrm{Cl}_{2}$ were added $\mathrm{PhI}(\mathrm{OAc})_{2}\left(2.77 \mathrm{~g}, 8.59 \mathrm{mmol}, 1.1\right.$ equiv) and $\mathrm{Rh}_{2}(\mathrm{esp})_{2}(59 \mathrm{mg}, 78 \mu \mathrm{mol}, 0.01$ equiv). After $9 \mathrm{~h}$, the reaction mixture was filtered through a small pad of Celite, washing the flask and filter cake with $50 \mathrm{~mL}$ of $\mathrm{CH}_{2} \mathrm{Cl}_{2}$. The combined filtrates were concentrated under reduced pressure to an oily residue. Analysis of the unpurified material by ${ }^{1} \mathrm{H}$ NMR showed a product ratio of $\sim 1.6: 1.3: 1.0$ aziridine/trans-oxathiazinane/cisoxathiazinane. Purification by chromatography on silica gel (gradient elution: 10:5:1 $\rightarrow 20: 5: 1$ $\mathrm{CH}_{2} \mathrm{Cl}_{2} /$ hexanes/Et $\mathrm{E}_{2} \mathrm{O}$ ) afforded the desired trans-oxathiazinane as a white solid (760 mg, 23\%): TLC $\mathrm{R}_{f}=0.22$ (20:5:1 $\mathrm{CH}_{2} \mathrm{Cl}_{2} /$ hexanes/Et $\left.2 \mathrm{O}\right) ;{ }^{1} \mathrm{H}$ NMR $\left(\mathrm{CD}_{3} \mathrm{CN}, 400 \mathrm{MHz}\right) \delta$ 7.40-7.25 (m, 5H), $6.73(\mathrm{~d}, 1 \mathrm{H}, J=15.9 \mathrm{~Hz}), 6.16$ $(\mathrm{d}, 1 \mathrm{H}, J=8.2 \mathrm{~Hz}), 6.12(\mathrm{dd}, 1 \mathrm{H}, J=15.9,7.8 \mathrm{~Hz}), 5.92(\mathrm{~d}, 1 \mathrm{H}, J=9.5 \mathrm{~Hz}), 4.77(\mathrm{~d}, 1 \mathrm{H}, J=12.2 \mathrm{~Hz}), 4.60(\mathrm{~d}, 1 \mathrm{H}$, $J=12.2 \mathrm{~Hz}$ ), 4.31 (ddd, $1 \mathrm{H}, J=9.5,9.5,9.5 \mathrm{~Hz}), 3.95$ (dddd, $1 \mathrm{H}, J=9.9,9.9,9.9,5.9 \mathrm{~Hz}) \mathrm{ppm} ;{ }^{13} \mathrm{C} \mathrm{NMR}\left(\mathrm{CDCl}_{3}\right.$, $100 \mathrm{MHz}) \delta 155.2,136.6,135.8,129.5,129.2,127.4,123.9,96.3,74.7,72.0,61.3,48.5 \mathrm{ppm}$; IR (thin film) v 3356, $3263,3031,2960,1718,1531,1437,1368,1286,1229,1179 \mathrm{~cm}^{-1}$; HRMS (ES $)$ calcd for $\mathrm{C}_{14} \mathrm{H}_{15} \mathrm{Cl}_{3} \mathrm{~N}_{2} \mathrm{O}_{5} \mathrm{~S}$ 427.9767 found $450.9660\left(\mathrm{MNa}^{+}\right)$.

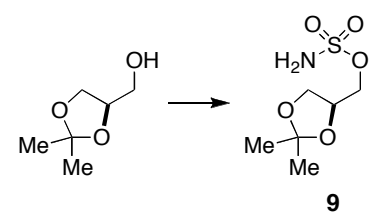

An oven-dried, 500-mL two-necked round bottom flask was fitted with a rubber septum and an oven-dried, 100-mL pressure equalizing addition funnel. The entire apparatus was flushed with $\mathrm{N}_{2}$ gas through an inlet on the addition funnel and kept under positive pressure. The flask was cooled to $0{ }^{\circ} \mathrm{C}$ in an ice-water bath and to the flask was added $60 \mathrm{~mL}$ of $\mathrm{CH}_{2} \mathrm{Cl}_{2}$, followed by $\mathrm{ClSO}_{2} \mathrm{NCO}(16.4 \mathrm{~mL}, 188 \mathrm{mmol}, 2.5 \mathrm{eq})$. The addition funnel was charged with $35 \mathrm{~mL}$ of $\mathrm{CH}_{2} \mathrm{Cl}_{2}$ and $\mathrm{HCO}_{2} \mathrm{H}(7.15 \mathrm{~mL}, 190 \mathrm{mmol}, 2.5 \mathrm{eq})$. The contents of the addition funnel were added dropwise over $15 \mathrm{~min}$ and the addition was made quantitative by rinsing the addition funnel with $5 \mathrm{~mL}$ of $\mathrm{CH}_{2} \mathrm{Cl}_{2}$. The resulting clear, colorless solution was stirred at $0{ }^{\circ} \mathrm{C}$ for 35 min then warmed to $23{ }^{\circ} \mathrm{C}$, and after stirring for $8 \mathrm{hr}$, the solution was cooled to $-10{ }^{\circ} \mathrm{C}$ with a methanol/ice bath. The addition funnel was charged with $(R)$-glycerol acetonide (10.0 g, $75 \mathrm{mmol}, 1.0 \mathrm{eq}), \mathrm{Et}_{3} \mathrm{~N}(32 \mathrm{ml}, 230 \mathrm{mmol}, 3.0 \mathrm{eq})$ and $20 \mathrm{~mL}$ of $\mathrm{CH}_{2} \mathrm{Cl}_{2}$, and the contents of the addition funnel were added dropwise over $15 \mathrm{~min}$. The bath was then removed and the resulting solution was stirred for $20 \mathrm{~min}$, concentrated, and diluted with $300 \mathrm{~mL}$ of EtOAc. The contents were poured into a $1 \mathrm{~L}$ separatory funnel and washed with $200 \mathrm{~mL}$ of $1 \mathrm{M}$ aqueous $\mathrm{K}_{2} \mathrm{HPO}_{4}(\mathrm{pH} \mathrm{10})$. The aqueous layer was extracted with $2 \times 100 \mathrm{~mL}$ of EtOAc and the combined organic extracts were dried over $\mathrm{MgSO}_{4}$, filtered and concentrated. The resulting colorless oil was purified by passing through a short pad of silica gel $(6.5 \mathrm{~cm} \times 3.5 \mathrm{~cm})$ using $700 \mathrm{~mL}$ of $1: 2$ hexanes/EtOAc to give sulfamate ester 9 as a colorless oil $(13.0 \mathrm{~g}, 81 \%)$ : TLC $\mathrm{R}_{\mathrm{f}}=0.56\left(1: 2\right.$ hexanes/EtOAc); ${ }^{1} \mathrm{H}$ $\operatorname{NMR}\left(\mathrm{CDCl}_{3}, 400 \mathrm{MHz}\right) \delta 5.12$ (br s, 2H), 4.41 (quint, $1 \mathrm{H}, J=5.6 \mathrm{~Hz}$ ), 4.24 (dd, $\left.1 \mathrm{H}, J=10.7,6.1 \mathrm{~Hz}\right), 4.18$ (dd, 
$1 \mathrm{H}, J=10.8,4.9 \mathrm{~Hz}), 4.12(\mathrm{dd}, 1 \mathrm{H}, J=8.8,6.5 \mathrm{~Hz}), 3.82(\mathrm{dd}, 1 \mathrm{H}, J=8.7,5.3 \mathrm{~Hz}), 1.48(\mathrm{~s}, 3 \mathrm{H}), 1.38(\mathrm{~s}, 3 \mathrm{H}) \mathrm{ppm}$; ${ }^{13} \mathrm{C} \mathrm{NMR}\left(\mathrm{CDCl}_{3}, 125 \mathrm{MHz}\right) \delta 110.1,72.8,70.1,65.3,26.2,24.8 \mathrm{ppm}$; IR (thin film) $v 3255,2988,1562,1372$, $1215,1180,1049,984,929 \mathrm{~cm}^{-1}$.

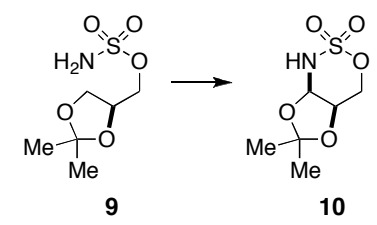

To a stirred suspension of sulfamate ester 9 (12.5 g, $59.2 \mathrm{mmol})$ and $\mathrm{MgO}$ (5.49 g, $136.2 \mathrm{mmol}, 2.3$ equiv) in 350 $\mathrm{mL}$ of $\mathrm{CH}_{2} \mathrm{Cl}_{2}$ were added successively $\mathrm{PhI}(\mathrm{OAc})_{2}\left(20.97 \mathrm{~g}, 65.1 \mathrm{mmol}, 1.1\right.$ equiv) and $\mathrm{Rh}_{2}(\mathrm{esp})_{2}(0.135 \mathrm{~g}, 0.178$ mmol, 0.003 equiv). The pale red mixture gradually turned to light green and was stirred for $7 \mathrm{~h}$. The contents were filtered through a pad of Celite using $300 \mathrm{~mL}$ of $\mathrm{CH}_{2} \mathrm{Cl}_{2}$ to rinse the filter cake. The combined filtrates were concentrated under reduced pressure and to the solid residue was added $40 \mathrm{~mL}$ of benzene followed by $5 \mathrm{~mL}$ of hexanes. After standing for $7 \mathrm{~h}$ the beige solid that had precipitated was collected in a sintered glass funnel and rinsed with cold benzene $(10 \mathrm{~mL})$ to give $8.45 \mathrm{~g}$ of the desired product $\mathbf{1 0}$ as a beige solid. The mother liquor was concentrated to a volume of $\sim 10 \mathrm{~mL}$ and stored for $24 \mathrm{~h}$ in a $-10^{\circ} \mathrm{C}$ freezer. Filtering this mixture gave an additional $1.00 \mathrm{~g}$ of product as a beige solid (9.45 g combined, 76\%): TLC $\mathrm{R}_{f}=0.48(1: 1 \mathrm{EtOAc} / \mathrm{hexanes})$; mp 96-97 ${ }^{\circ} \mathrm{C} ;[\alpha]_{\mathrm{D}}-44.1^{\circ}(\mathrm{c}=1.50, \mathrm{MeOH}) ;{ }^{1} \mathrm{H} \mathrm{NMR}\left(\mathrm{CD}_{3} \mathrm{OD}, 500 \mathrm{MHz}\right) \delta 5.42(\mathrm{~d}, 1 \mathrm{H}, J=5.3 \mathrm{~Hz}), 4.59-4.58(\mathrm{~m}$, $2 \mathrm{H}), 4.31(\mathrm{ddd}, 1 \mathrm{H}, J=5.3,1.6,1.6 \mathrm{~Hz}), 1.54(\mathrm{~s}, 3 \mathrm{H}), 1.35(\mathrm{~s}, 3 \mathrm{H}) \mathrm{ppm} ;{ }^{13} \mathrm{C} \mathrm{NMR}\left(\mathrm{CD}_{3} \mathrm{OD}, 125 \mathrm{MHz}\right) \delta 111.5$, 85.6, 71.7, 71.5, 26.9, 25.6 ppm; IR (KBr pellet) $v$ 3260, 2997, 2979, 1456, 1390, 1379, 1354, 1245, $1180,1071 \mathrm{~cm}^{-}$ ${ }^{1}$; HRMS $\left(\mathrm{ES}^{+}\right)$calcd for $\mathrm{C}_{6} \mathrm{H}_{11} \mathrm{NO}_{5} \mathrm{~S} 209.0358$ found $232.0246\left(\mathrm{MNa}^{+}\right)$.

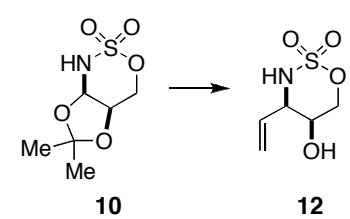

A 2-neck flask equipped with a rubber septum and glass stopper was charged with $194 \mathrm{~mL}$ of $0.80 \mathrm{M}$ vinyl magnesium bromide (154.6 mmol, 4.2 equiv) in THF and placed in an ice bath. To this solution was added dropwise over $15 \mathrm{~min}, 80 \mathrm{~mL}$ of $1.0 \mathrm{M} \mathrm{ZnCl}_{2}$ in THF $(80.0 \mathrm{mmol}, 2.2 \mathrm{mmol})$. The mixture was stirred for $15 \mathrm{~min}$ at $0{ }^{\circ} \mathrm{C}$, then warmed to $23{ }^{\circ} \mathrm{C}$ and stirred for $30 \mathrm{~min}$. After this time, the contents were cooled to $0{ }^{\circ} \mathrm{C}$, the flask briefly unstoppered, and solid $N, O$-acetal $10(7.70 \mathrm{~g}, 36.80 \mathrm{mmol})$ was added in five equal portions at $1 \mathrm{~min}$ intervals. The reaction mixture was stirred for $10 \mathrm{~min}$ at $0{ }^{\circ} \mathrm{C}$, then warmed to $50{ }^{\circ} \mathrm{C}$ and stirred for $15 \mathrm{~min}$. The solution was once again cooled to $0{ }^{\circ} \mathrm{C}$ and the reaction quenched by the slow addition of $150 \mathrm{~mL}$ of saturated aqueous $\mathrm{NH}_{4} \mathrm{Cl}$. The biphasic mixture was transferred to a separatory funnel with $300 \mathrm{~mL}$ of EtOAc and $100 \mathrm{~mL}$ of $\mathrm{H}_{2} \mathrm{O}$. The organic phase was collected and the aqueous phase was extracted with $3 \times 100 \mathrm{~mL}$ of EtOAc. The combined organic extracts were dried over $\mathrm{Na}_{2} \mathrm{SO}_{4}$, filtered, and concentrated under reduced pressure to a light orange, amorphous solid. Purification by chromatography on silica gel (gradient elution: $2: 1 \rightarrow 1: 2$ hexanes/EtOAc) afforded vinyl oxathiazinane 12 as a white solid $(4.51 \mathrm{~g}, 68 \%)$ : $\quad$ TLC $\mathrm{R}_{f}=0.29(1: 1 \mathrm{hexanes} / \mathrm{EtOAc}) ;{ }^{1} \mathrm{H}$ NMR $\left(\mathrm{CD}_{3} \mathrm{OD}, 400 \mathrm{MHz}\right) \delta 5.90(\mathrm{ddd}, 1 \mathrm{H}, J=17.2,10.7,5.5 \mathrm{~Hz}), 5.35(\mathrm{ddd}, 1 \mathrm{H}, J=17.4,1.7,1.2 \mathrm{~Hz}), 5.28(\mathrm{ddd}, 1 \mathrm{H}, J$ $=10.7,1.5,1.5 \mathrm{~Hz}), 4.73(\mathrm{dd}, 1 \mathrm{H}, J=12.2,1.4 \mathrm{~Hz}), 4.32(\mathrm{dddd}, 1 \mathrm{H}, J=5.6,2.0,2.0,2.0 \mathrm{~Hz}), 3.62(\mathrm{ddd}, 1 \mathrm{H}, J=$ 1.7, 1.7, $1.7 \mathrm{~Hz}) \mathrm{ppm} ;{ }^{13} \mathrm{C} \mathrm{NMR}\left(\mathrm{CD}_{3} \mathrm{OD}, 100 \mathrm{MHz}\right) \delta 134.5,117.9,77.9,63.7,62.2 \mathrm{ppm}$; IR (thin film) $v 3523$ (br), 3255, 1432, 1361, $1188 \mathrm{~cm}^{-1}$; HRMS $\left(\mathrm{ES}^{+}\right)$calcd for $\mathrm{C}_{5} \mathrm{H}_{9} \mathrm{NO}_{4} \mathrm{~S} 179.0252$ found $202.0159\left(\mathrm{MNa}^{+}\right)$.

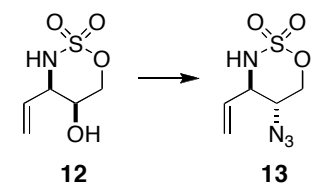

To a solution of vinyl oxathiazinane 12 (4.29 g, $23.9 \mathrm{mmol})$ in $80 \mathrm{~mL}$ of MeCN were added successively powdered, anhydrous $\mathrm{K}_{2} \mathrm{CO}_{3}$ (9.93 g, $71.8 \mathrm{mmol}, 3.0$ equiv), p-methoxybenzyl chloride (6.50 mL, $47.9 \mathrm{mmol}, 2.0$ equiv) and ${ }^{\mathrm{n}} \mathrm{Bu}_{4} \mathrm{NI}$ (1.33 g, $3.60 \mathrm{mmol}, 0.15$ equiv). The orange mixture was stirred at $23{ }^{\circ} \mathrm{C}$ for $9 \mathrm{~h}$, then filtered through a small pad of Celite. The flask and filter cake were rinsed with $200 \mathrm{~mL}$ of EtOAc and the combined filtrates were 
transferred to a separatory funnel. The organic layer was washed with $2 \times 60 \mathrm{~mL}$ of $1 / 2$ saturated aqueous $\mathrm{NaCl}$. The organic phase was collected and the aqueous layer was extracted with $2 \times 50 \mathrm{~mL}$ of EtOAc. The combined organic extracts were dried over $\mathrm{Na}_{2} \mathrm{SO}_{4}$, filtered, and concentrated under reduced pressure to a light orange oil. Purification of this material by chromatography on silica gel (gradient elution: $2: 2: 1 \quad \mathrm{CH}_{2} \mathrm{Cl}_{2} /$ hexanes/EtOAc $\rightarrow$ neat EtOAc) afforded $N$-PMB-oxathiazinane as a colorless oil (5.07 g, 71\%). A small portion of unreacted starting material 12 was also recovered as a white solid $(708 \mathrm{mg})$ : $\mathrm{TLC} \mathrm{R}_{f}=0.38\left(1: 1\right.$ hexanes/EtOAc); ${ }^{1} \mathrm{H} \mathrm{NMR}\left(\mathrm{CDCl}_{3}\right.$, $400 \mathrm{MHz}) \delta$ 7.28-7.22 (m, 2H), 6.89-6.84 (m, 2H), $6.02(\mathrm{ddd}, 1 \mathrm{H}, J=17.2,10.4,8.7 \mathrm{~Hz}), 5.48-5.44(\mathrm{~m}, 1 \mathrm{H}), 5.44-$ $5.39(\mathrm{~m}, 1 \mathrm{H}), 4.71(\mathrm{dd}, 1 \mathrm{H}, J=11.9,2.4 \mathrm{~Hz}), 4.48(\mathrm{dd}, 1 \mathrm{H}, J=11.8,4.3 \mathrm{~Hz}), 4.35(\mathrm{~s}, 2 \mathrm{H}), 4.23(\mathrm{dd}, 1 \mathrm{H}, J=8.7,2.9$ $\mathrm{Hz}), 3.88-3.80$ (m, 1H), 3.80 (s, 3H) 2.25 (br s, 1H) ppm.

To a solution of $N$-PMB-oxathiazinane $(5.68 \mathrm{~g}, 19.0 \mathrm{mmol})$, pyridine $(13.0 \mathrm{~mL}, 159.4 \mathrm{mmol}, 8.4$ equiv) and DMAP (232 mg, $1.90 \mathrm{mmol}, 0.10$ equiv) in $25 \mathrm{~mL}$ of toluene at $0{ }^{\circ} \mathrm{C}$ was added dropwise over 15 min $28.0 \mathrm{~mL}$ of a $2.0 \mathrm{M}$ toluene solution of trifluoromethanesulfonic anhydride $\left(56.9 \mathrm{mmol}, 3.0\right.$ equiv). The mixture was stirred at $0{ }^{\circ} \mathrm{C}$ for $10 \mathrm{~min}$, then transferred to a separatory funnel containing $150 \mathrm{~mL}$ of ice cold $10 \%$ aqueous $\mathrm{NaHSO}_{4}$ and $300 \mathrm{~mL}$ of EtOAc. The organic phase was collected and the aqueous layer was extracted with $3 \times 50 \mathrm{~mL}$ of EtOAc. The combined organic extracts were dried over $\mathrm{Na}_{2} \mathrm{SO}_{4}$ and filtered. Note: the triflate product appears to decompose when concentrated to dryness. Accordingly, $65 \mathrm{~mL}$ of DMF was added to the filtrate and the volatiles (EtOAc and toluene) were removed under reduced pressure. The DMF solution of unpurified triflate was cooled to $-15^{\circ} \mathrm{C}$ (MeOH/ice bath) and solid $\mathrm{NaN}_{3}(6.17 \mathrm{~g}, 94.9 \mathrm{mmol}, 5.0$ equiv) was added in a single portion. The orange reaction mixture was warmed to $-10{ }^{\circ} \mathrm{C}$ over $30 \mathrm{~min}$, and poured into a separatory funnel containing $150 \mathrm{~mL}$ of $10 \%$ aqueous $\mathrm{NaHSO}_{4}, 300 \mathrm{~mL}$ of $\mathrm{Et}_{2} \mathrm{O}$, and $150 \mathrm{~mL}$ of EtOAc. The organic phase was collected and the aqueous layer was extracted with $2 \times 100 \mathrm{~mL}$ of $2: 1 \mathrm{Et}_{2} \mathrm{O} / \mathrm{EtOAc}$ and $1 \times 100 \mathrm{~mL}$ of $1: 1 \mathrm{Et}_{2} \mathrm{O} / \mathrm{EtOAc}$. The combined organic extracts were dried over $\mathrm{MgSO}_{4}$, filtered, and concentrated under reduced pressure. Purification of the oily residue by chromatography on silica gel (5:1 hexanes/acetone) afforded the desired azide as a colorless oil (474 $\mathrm{mg}, 8 \%$ over 2 steps): TLC $\mathrm{R}_{f}=0.20$ (5:1 hexanes/acetone); ${ }^{1} \mathrm{H}$ NMR $\left(\mathrm{CDCl}_{3}, 400 \mathrm{MHz}\right) \delta$ 7.30-7.24 (m, 2H), 6.92-6.87 (m, 2H), $6.14(\mathrm{ddd}, 1 \mathrm{H}, J=17.1,10.4,8.7 \mathrm{~Hz}), 5.45(\mathrm{ddd}, 1 \mathrm{H}, J=10.4,0.8,0.8 \mathrm{~Hz}), 5.29(\mathrm{ddd}, 1 \mathrm{H}, J=17.1,0.9,0.9$ Hz) 4.87 (dd, $1 \mathrm{H}, J=12.2,2.8 \mathrm{~Hz}), 4.59$ (d, $1 \mathrm{H}, J=14.4 \mathrm{~Hz}), 4.51$ (ddd, $1 \mathrm{H}, J=12.2,4.4,1.5 \mathrm{~Hz}), 4.17$ (d, $1 \mathrm{H}, J=$ $14.2 \mathrm{~Hz}$ ), 3.98-3.93 (m, 1H), 3.82 (s, 3H), 3.43 (ddd, $1 \mathrm{H}, J=4.3,4.3,2.9 \mathrm{~Hz}) \mathrm{ppm}$.

Azide $(474 \mathrm{mg}, 1.46 \mathrm{mmol})$ and $\left(\mathrm{NH}_{4}\right)_{2} \mathrm{Ce}\left(\mathrm{NO}_{3}\right)_{6}(4.00 \mathrm{~g}, 7.31 \mathrm{mmol}, 5.0$ equiv) were combined in $10 \mathrm{~mL}$ of $4: 1$ ${ }^{t} \mathrm{BuOH} / \mathrm{CH}_{2} \mathrm{Cl}_{2}$ and the resulting orange suspension was warmed to $55^{\circ} \mathrm{C}$. After stirring at this temperature for $9 \mathrm{~h}$, the reaction mixture was diluted with $60 \mathrm{~mL}$ of EtOAc and poured into a separatory funnel containing $40 \mathrm{~mL}$ of $1 / 2$ saturated aqueous $\mathrm{NaCl}$. The organic layer was separated and the aqueous phase was extracted with $2 \times 20 \mathrm{~mL}$ of EtOAc. The combined organic extracts were washed with $30 \mathrm{~mL}$ of saturated aqueous $\mathrm{NaCl}$, dried over $\mathrm{Na}_{2} \mathrm{SO}_{4}$, filtered, and concentrated under reduced pressure. Purification of the oily residue by chromatography on silica gel (gradient elution: 6:1 $\rightarrow 4: 1$ hexanes/acetone) afforded the desired azido-oxathiazinane $\mathbf{1 3}$ as a pale yellow oil (275 mg, 92\%): TLC $\mathrm{R}_{f}=0.25$ (3:1 hexanes/acetone); ${ }^{1} \mathrm{H}$ NMR $\left(\mathrm{CDCl}_{3}, 400 \mathrm{MHz}\right) \delta 5.93$ (ddd, $1 \mathrm{H}, J=17.1,10.5,6.3$ $\mathrm{Hz}), 5.51(\mathrm{ddd}, 1 \mathrm{H}, J=17.2,1.4,0.3 \mathrm{~Hz}), 5.49(\mathrm{ddd}, 1 \mathrm{H}, J=10.4,1.2,0.3 \mathrm{~Hz}), 4.58(\mathrm{dd}, 1 \mathrm{H}, J=11.8,5.0 \mathrm{~Hz}), 4.53$ $(\mathrm{d}, 1 \mathrm{H}, J=9.2 \mathrm{~Hz}$ ), 4.48 (dd, $1 \mathrm{H}, J=11.7,9.9 \mathrm{~Hz}), 4.15$ (dddd, $1 \mathrm{H}, J=9.3,9.3,6.3,1.4,1.4 \mathrm{~Hz}$ ), 3.58 (ddd, $1 \mathrm{H}, J$ $=9.8,9.8,5.0 \mathrm{~Hz}) \mathrm{ppm} ;{ }^{13} \mathrm{C} \mathrm{NMR}\left(\mathrm{CDCl}_{3}, 100 \mathrm{MHz}\right) \delta 131.4,121.1,71.0,60.4,56.1 \mathrm{ppm}$; IR (thin film) $v 3271$, 2115, 1434, 1368, $1189 \mathrm{~cm}^{-1}$; HRMS (ES ${ }^{+}$calcd for $\mathrm{C}_{5} \mathrm{H}_{8} \mathrm{~N}_{4} \mathrm{O}_{3} \mathrm{~S} 204.0317$ found $227.0210\left(\mathrm{MNa}^{+}\right)$.

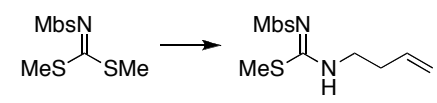

To a suspension of [(4-methoxyphenyl)sulfonyl]carbonimidodithioic acid dimethyl ester (258 $\mathrm{mg}, 885 \mu \mathrm{mol})$ in 2.0 $\mathrm{mL}$ of $\mathrm{MeOH}$ were added 3-butenylamine hydrochloride ( $100 \mathrm{mg}, 0.93 \mathrm{mmol}, 1.05$ equiv) and $\mathrm{Et}_{3} \mathrm{~N}(0.14 \mathrm{~mL}, 0.97$ mmol, 1.1 equiv). The reaction flask was equipped with a reflux condenser and the vessel was submerged in an oil bath pre-heated to $50{ }^{\circ} \mathrm{C}$. The contents were stirred at this temperature for $30 \mathrm{~min}$. The mixture was then cooled to $23{ }^{\circ} \mathrm{C}$, the solution concentrated under reduced pressure to $\sim 1 / 3$ the original volume, and transferred to a separatory funnel with $50 \mathrm{~mL}$ of EtOAc and $25 \mathrm{~mL}$ of $10 \%$ aqueous $\mathrm{NaHSO}_{4}$. The organic phase was collected and the aqueous layer was extracted with $3 \times 10 \mathrm{~mL}$ of EtOAc. The combined organic extracts were dried over $\mathrm{Na}_{2} \mathrm{SO}_{4}$, filtered, and concentrated under reduced pressure to an oily residue. Purification of this material by chromatography on silica gel (2:1 hexanes/EtOAc) afforded butenyl isothiourea as a colorless oil ( $259 \mathrm{mg}, 93 \%)$ : TLC $\mathrm{R}_{f}=0.21(2: 1$ 
hexanes/EtOAc); ${ }^{1} \mathrm{H}$ NMR $\left(\mathrm{CDCl}_{3}, 500 \mathrm{MHz}\right) \delta 8.17$ (br s, 1H), 7.87-7.79 (m, 2H), 6.97-6.90 (m, 2H), 5.74 (ddt, $1 \mathrm{H}, J=16.7,9.9,6.8 \mathrm{~Hz}), 5.21-5.18(\mathrm{~m}, 1 \mathrm{H}), 5.18-5.15(\mathrm{~m}, 1 \mathrm{H}), 3.85(\mathrm{~s}, 3 \mathrm{H}), 3.35(\mathrm{dt}, 2 \mathrm{H}, J=6.6,6.6 \mathrm{~Hz}), 2.39$ $(\mathrm{m}, 2 \mathrm{H}), 2.36(\mathrm{~s}, 3 \mathrm{H}) \mathrm{ppm} .{ }^{13} \mathrm{C} \mathrm{NMR}\left(\mathrm{CDCl}_{3}, 100 \mathrm{MHz}\right) \delta 168.8,162.2,134.2,133.4,128.0,118.4,113.6,55.3$, 42.9, 33.0, 13.9 ppm; IR (thin film) v 3292, 3079, 2932, 1574, 1498, 1257, 1138, 1089, 1079, 859, $834 \mathrm{~cm}^{-1}$; HRMS $\left(\mathrm{ES}^{+}\right)$calcd for $\mathrm{C}_{13} \mathrm{H}_{18} \mathrm{~N}_{2} \mathrm{O}_{3} \mathrm{~S}_{2} 314.0759$ found $337.0651\left(\mathrm{MNa}^{+}\right)$.

$$
\mathrm{MeS}_{\mathrm{SMe}}^{\mathrm{MbsN}} \longrightarrow{ }_{\text {MeS }}^{\text {MbsN }}{ }_{\mathrm{Cl}}
$$

[(4-Methoxyphenyl)sulfonyl]carbonochloridimidothioic acid methyl ester. To a stirred solution of [(4methoxyphenyl)sulfonyl]carbonimidodithioic acid dimethyl ester $(7.40 \mathrm{~g}, 25.4 \mathrm{mmol})$ in $75 \mathrm{~mL}$ of $\mathrm{CH}_{2} \mathrm{Cl}_{2}$ was added dropwise sulfuryl chloride $(4.10 \mathrm{~mL}, 51.0 \mathrm{mmol}, 2.0$ equiv). The resulting yellow solution was warmed to 40 ${ }^{\circ} \mathrm{C}$ and stirred for $3 \mathrm{~h}$. After this time, the mixture was cooled to $23{ }^{\circ} \mathrm{C}$ and concentrated under reduced pressure. Purification of the solid residue by chromatography on silica gel ( $7: 3$ hexanes/EtOAc) gave the desired product $(6.90 \mathrm{~g}, 97 \%)$ as a pale yellow solid: $\mathrm{TLC} \mathrm{R}_{f}=0.50$ (7:3 hexanes/EtOAc); ${ }^{1} \mathrm{H}$ NMR $\left(\mathrm{CDCl}_{3}, 300 \mathrm{MHz}\right) \delta 7.95(\mathrm{~m}$, 2H), 7.04 (m, 2H), 3.89 (s, 3H), 2.44 (s, 3H) ppm.

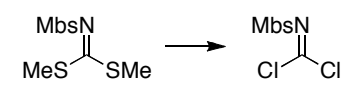

[(4-Methoxyphenyl)sulfonyl]carbonimidic dichloride. A $25 \mathrm{~mL}$ 2-neck flask equipped with a dropping funnel and a gas outlet was charged with $\mathrm{KMnO}_{4}(4.00 \mathrm{~g}, 25.3 \mathrm{mmol})$. With the aid of the dropping funnel, commercialgrade, concentrated $\mathrm{HCl}\left(27 \mathrm{~mL}, 324 \mathrm{mmol}, \sim 13\right.$ equiv) was slowly added to the solid mass. Evolution of $\mathrm{Cl}_{2}$ gas immediately ensued. The gas was allowed to escape the vessel through the outlet and passed successively into solutions of $\mathrm{H}_{2} \mathrm{O}$ and concentrated $\mathrm{H}_{2} \mathrm{SO}_{4}$ (note: Teflon tubing was used for this operation; the procedure for $\mathrm{Cl}_{2}$ generation follows a reported method $\left.{ }^{6}\right)$. The purified $\mathrm{Cl}_{2}$ gas was bubbled over $\sim 1.5 \mathrm{~h}$ into a suspension of [(4methoxyphenyl)sulfonyl]-carbonimidodithioic acid dimethyl ester $(2.02 \mathrm{~g}, 6.93 \mathrm{mmol})$ in $20 \mathrm{~mL}$ of glacial AcOH held in an ice- $\mathrm{H}_{2} \mathrm{O}$ bath at $12-14{ }^{\circ} \mathrm{C}$. After gas evolution ceased, the resulting pale green solution was stirred for 20 min at $12-14{ }^{\circ} \mathrm{C}$ then sparged briefly with $\mathrm{N}_{2}$ and concentrated in vacuo. Purification of the resulting solid mass by sublimation $\left(85-90{ }^{\circ} \mathrm{C}, \sim 0.1 \mathrm{~mm} \mathrm{Hg}\right)$ gave the desired dichloride as white needles $(1.65 \mathrm{~g}, 89 \%)$ : ${ }^{1} \mathrm{H} \mathrm{NMR}\left(\mathrm{CDCl}_{3}\right.$, $400 \mathrm{MHz}) \delta 7.90$ (m, 2H), $7.05(\mathrm{~m}, 2 \mathrm{H}), 3.88$ (s, 3H) ppm.

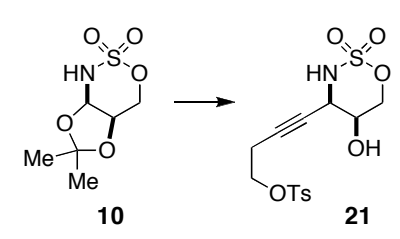

To a solution of 4-( $p$-toluylsulfonyloxy)-1-butyne (23.2 g, $103 \mathrm{mmol}, 2.1$ equiv) in $45 \mathrm{~mL}$ of THF at $-78{ }^{\circ} \mathrm{C}$ was added dropwise a $2.5 \mathrm{M}$ hexanes solution of $n$ - $\mathrm{BuLi}(39.4 \mathrm{~mL}, 98.5 \mathrm{mmol}, 2.0$ equiv). The resulting viscous orange suspension was stirred for $20 \mathrm{~min}$ at $-78{ }^{\circ} \mathrm{C}$. A solution of $\mathrm{ZnCl}_{2}(14.1 \mathrm{~g}, 103 \mathrm{mmol}, 2.1$ equiv) in $73 \mathrm{~mL}$ of THF was added dropwise via cannula. Transfer of the $\mathrm{ZnCl}_{2}$ was made quantitative with an additional $5 \mathrm{~mL}$ of THF, and the resulting yellow mixture was warmed to $23{ }^{\circ} \mathrm{C}$ and stirred for $30 \mathrm{~min}$ at this temperature. Following this time, the solution was cooled to $0{ }^{\circ} \mathrm{C}$, and neat $\mathrm{BF}_{3} \cdot \mathrm{OEt}_{2}(18.7 \mathrm{~mL}, 148 \mathrm{mmol}, 3.0$ equiv) was added dropwise. The yellow homogeneous mixture was maintained at $0{ }^{\circ} \mathrm{C}$ and stirred for $3 \mathrm{~min}$ before a solution of oxathiazinane 10 (10.1 g, $48.3 \mathrm{mmol})$ in $22 \mathrm{~mL}$ of THF was added via cannula. An additional $10 \mathrm{~mL}$ of THF was used to ensure quantitative transfer of the oxathiazinane. The reaction flask was then transferred from the $0{ }^{\circ} \mathrm{C}$ ice/water bath to an oil bath preheated to $40^{\circ} \mathrm{C}$. The light yellow mixture was stirred at $40{ }^{\circ} \mathrm{C}$ for $20 \mathrm{~min}$ then removed from the oil bath and quenched by the addition of $120 \mathrm{~mL}$ of saturated aqueous $\mathrm{NH}_{4} \mathrm{Cl}$. The biphasic contents were transferred to a separatory funnel containing $120 \mathrm{~mL}$ of $\mathrm{Et}_{2} \mathrm{O}$ and $150 \mathrm{~mL}$ of saturated aqueous $\mathrm{NH}_{4} \mathrm{Cl}$. The organic phase was collected and the aqueous layer was extracted with $150 \mathrm{~mL}$ of $\mathrm{Et}_{2} \mathrm{O}$. The combined organic extracts were washed with $300 \mathrm{~mL}$ of a 1:1 saturated aqueous $\mathrm{NaHCO}_{3} /$ saturated aqueous $\mathrm{NaCl}$ solution, dried over $\mathrm{MgSO}_{4}$, and concentrated under reduced pressure. The resulting orange solid was dissolved in $75 \mathrm{~mL}$ of boiling $\mathrm{CHCl}_{3}$. Hexanes $(50 \mathrm{~mL})$ was added slowly $(1 \mathrm{~min})$, and the cloudy mixture was allowed to stand at $23{ }^{\circ} \mathrm{C}$ for $1 \mathrm{~h}$ and then at $0{ }^{\circ} \mathrm{C}$ for $1 \mathrm{~h}$ (if an oil results, trituration at $0{ }^{\circ} \mathrm{C}$ will induce precipitation). The solid was collected on a Büchner funnel and washed with $75 \mathrm{~mL}$ of a $1: 1 \mathrm{CHCl}_{3} /$ hexanes mixture to give the desired product 21 as a beige powder 
(14.1 g, 78\%): TLC $\mathrm{R}_{f}=0.34\left(2: 3\right.$ hexanes/EtOAc); $\mathrm{mp}=112-114{ }^{\circ} \mathrm{C} ;[\alpha]_{\mathrm{D}}-10.4^{\circ}(\mathrm{c}=2.40, \mathrm{MeOH}) ;{ }^{1} \mathrm{H}$ NMR $\left(\mathrm{CD}_{3} \mathrm{OD}, 500 \mathrm{MHz}\right) \delta 7.85(\mathrm{~m}, 2 \mathrm{H}), 7.50(\mathrm{~m}, 2 \mathrm{H}),, 4.68(\mathrm{dd}, 1 \mathrm{H}, J=12.3,1.4 \mathrm{~Hz}), 4.56(\mathrm{br} \mathrm{d}, 1 \mathrm{H}, J=1.8 \mathrm{~Hz}), 4.42$ $(\mathrm{dd}, 1 \mathrm{H}, J=12.3,2.2 \mathrm{~Hz}), 4.12(\mathrm{t}, 2 \mathrm{H}, J=6.5 \mathrm{~Hz}), 3.61(\mathrm{dd}, 1 \mathrm{H}, J=4.3,1.8 \mathrm{~Hz}), 2.62(\mathrm{dt}, 2 \mathrm{H}, J=6.5,2.1 \mathrm{~Hz})$, $2.50(\mathrm{~s}, 3 \mathrm{H}) \mathrm{ppm} ;{ }^{13} \mathrm{C}$ NMR $\left(\mathrm{d}_{6}\right.$-acetone, $\left.125 \mathrm{MHz}\right) \delta 146.0,133.9,130.9,128.7,82.2,77.2,76.6,68.7,63.2,53.3$, 21.5, 20.0 ppm; IR (KBr pellet) v 3477, 3220, 2260, 1380, 1353, 1175, 1012, $963 \mathrm{~cm}^{-1}$; HRMS (ES ${ }^{+}$) calcd for $\mathrm{C}_{14} \mathrm{H}_{17} \mathrm{NO}_{7} \mathrm{~S}_{2} 375.0446$ found $398.0334\left(\mathrm{MNa}^{+}\right)$.

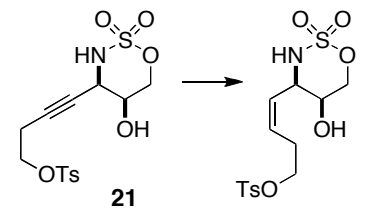

Alkyne 21 (10.25 g, $27.3 \mathrm{mmol}$ ) was dissolved in $140 \mathrm{~mL}$ of THF. Lindlar's catalyst ( $5 \mathrm{wt} \% \mathrm{Pd} / \mathrm{CaCO} / \mathrm{Pb}, 3.49 \mathrm{~g}$, $1.6 \mathrm{mmol}, 0.06$ equiv) and quinoline (546 mg, $4.4 \mathrm{mmol}, 0.16$ equiv) were added sequentially. The flask was fitted with a balloon of $\mathrm{H}_{2}$ and the black suspension was stirred vigorously for $80 \mathrm{~min}$. The reaction mixture was filtered through a pad of Celite $(40 \times 70 \mathrm{~mm})$, and the filter cake was washed with $\sim 100 \mathrm{~mL}$ of $\mathrm{CH}_{2} \mathrm{Cl}_{2}$. The combined filtrates were concentrated under reduced pressure to a pale yellow foam and the alkene product was used without further purification ( $>95 \%$ yield, $\sim 0.1$ equiv of quinoline remaining). A sample of pure material was obtained by chromatography on silica gel (2:3 hexanes/EtOAc): $\mathrm{TLC}_{f}=0.34$ (2:3 hexanes/EtOAc); ${ }^{1} \mathrm{H}$ NMR $\left(\mathrm{CDCl}_{3}, 400\right.$ MHz) $\delta$ 7.78-7.76 (m, 2H), 7.38-7.38 (m, 2H), 5.72-5.62 (m, 2H), 4.90 (br s, 1H), 4.80 (dd, 1H, $J=12.4,1.4 \mathrm{~Hz})$, 4.56 (br d, $1 \mathrm{H}, J=5.3 \mathrm{~Hz}$ ), 4.51 (dd, $1 \mathrm{H}, J=12.4,2.0 \mathrm{~Hz}$ ), 4.14-4.02 (m, 2H), 3.69 (dd, $1 \mathrm{H}, J=3.2,1.8 \mathrm{~Hz}), 2.62-$ $2.50(\mathrm{~m}, 1 \mathrm{H}), 2.49-2.42(\mathrm{~m}, 1 \mathrm{H}), 2.46(\mathrm{~s}, 3 \mathrm{H}) \mathrm{ppm} ;{ }^{13} \mathrm{C} \mathrm{NMR}\left(\mathrm{CDCl}_{3}, 100 \mathrm{MHz}\right) \delta 145.3,132.6,130.6,130.1$, 127.9, 126.9, 76.7, 69.1, 63.1, 56.6, 28.0, $21.8 \mathrm{ppm}$; IR (thin film) v 3523, 3261, 2960, 1598, 1427, 1356, 1188, $1175,1020,917 \mathrm{~cm}^{-1}$; HRMS (ES ${ }^{+}$) calcd for $\mathrm{C}_{14} \mathrm{H}_{19} \mathrm{NO}_{7} \mathrm{~S}_{2} 377.0603$ found $400.0500\left(\mathrm{MNa}^{+}\right)$.

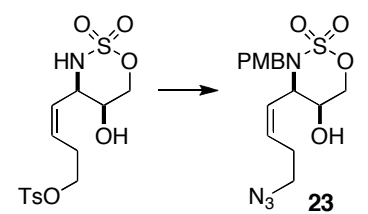

The starting tosylate was dissolved in $80 \mathrm{~mL}$ of DMF and to this solution was added $\mathrm{NaN}_{3}$ (3.54 g, $54.5 \mathrm{mmol}, 2.0$ equiv) and ${ }^{\mathrm{n}} \mathrm{Bu}_{4} \mathrm{NI}(1.71 \mathrm{~g}, 5.5 \mathrm{mmol}, 0.20$ equiv). The light orange mixture was stirred for $7 \mathrm{~h}$ then poured into a separatory funnel with $350 \mathrm{~mL}$ of $\mathrm{Et}_{2} \mathrm{O}$ and $250 \mathrm{~mL}$ of $\mathrm{H}_{2} \mathrm{O}$. The organic phase was collected and the aqueous layer was extracted with $2 \times 150 \mathrm{~mL}$ of $\mathrm{Et}_{2} \mathrm{O}$ and $2 \times 150 \mathrm{~mL}$ of EtOAc. The combined organic extracts were washed successively with $2 \times 100 \mathrm{~mL}$ of $\mathrm{H}_{2} \mathrm{O}$ and $1 \times 100 \mathrm{~mL}$ of saturated aqueous $\mathrm{NaCl}$, dried over $\mathrm{MgSO}_{4}$, and concentrated under reduced pressure. The isolated material was purified by chromatography on silica gel (9:11 hexanes/EtOAc) to afford the desired azide with $\sim 10 \%$ of quinoline (as determined by ${ }^{1} \mathrm{H}$ NMR) remaining from the prior hydrogenation reaction. After re-dissolving the product azide in $100 \mathrm{~mL}$ of MeCN, powdered, anhydrous $\mathrm{K}_{2} \mathrm{CO}_{3}$ (10.2 g, $74.1 \mathrm{mmol}, 3.0$ equiv), p-methoxybenzyl chloride $\left(6.70 \mathrm{~mL}, 49.4 \mathrm{mmol}, 2.0\right.$ equiv), and ${ }^{\mathrm{n}} \mathrm{Bu}_{4} \mathrm{NI}$ $(1.16 \mathrm{~g}, 3.7 \mathrm{mmol}, 0.15$ equiv) were added. The orange mixture was stirred for $10 \mathrm{~h}$ then filtered through a pad of Celite $(40 \times 70 \mathrm{~mm})$ washing the filter cake with $200 \mathrm{~mL}$ of $\mathrm{CH}_{2} \mathrm{Cl}_{2}$. The combined filtrates were concentrated under reduced pressure to give an oily residue that was purified by chromatography on silica gel (3:2 hexanes/EtOAc). The desired product 23 was obtained as a pale yellow foam $\left(7.40 \mathrm{~g}, 80 \%\right.$ over 3 steps): $\mathrm{TLC} \mathrm{R}_{f}=$ $0.62\left(2: 3\right.$ hexanes/EtOAc); $[\alpha]_{\mathrm{D}}+54.1^{\circ}\left(\mathrm{c}=2.60, \mathrm{CHCl}_{3}\right) ;{ }^{1} \mathrm{H}$ NMR $\left(\mathrm{CDCl}_{3}, 500 \mathrm{MHz}\right) \delta$ 7.24-7.22 (m, 2H), 6.86$6.84(\mathrm{~m}, 2 \mathrm{H}), 5.90(\mathrm{dddd}, 1 \mathrm{H}, J=11.1,9.6,1.5,1.5 \mathrm{~Hz}), 5.80-5.75(\mathrm{~m}, 1 \mathrm{H}), 4.71(\mathrm{dd}, 1 \mathrm{H}, J=11.8,2.4 \mathrm{~Hz}), 4.56$ $(\mathrm{dd}, 1 \mathrm{H}, J=9.5,2.8 \mathrm{~Hz}), 4.48(\mathrm{dd}, 1 \mathrm{H}, J=11.8,4.4 \mathrm{~Hz}), 4.40(\mathrm{~d}, 1 \mathrm{H}, J=15.4 \mathrm{~Hz}), 4.31$ (d, $1 \mathrm{H}, J=15.4 \mathrm{~Hz}), 3.82-$ $8.79(\mathrm{~m}, 1 \mathrm{H}), 3.80(\mathrm{~s}, 3 \mathrm{H}), 3.34-3.30(\mathrm{~m}, 1 \mathrm{H}), 3.24$ (ddd, $1 \mathrm{H}, J=12.2,8.2,5.6 \mathrm{~Hz}), 2.45(\mathrm{~d}, 1 \mathrm{H}, J=8.7), 2.29-2.22$ $(\mathrm{m}, 1 \mathrm{H}), 2.22-2.14(\mathrm{~m}, 1 \mathrm{H}) \mathrm{ppm} ;{ }^{13} \mathrm{C} \mathrm{NMR}\left(\mathrm{CDCl}_{3}, 125 \mathrm{MHz}\right) \delta 159.1,134.2,129.6,128.6,124.6,113.9,75.2$, 65.0, 59.0, 55.2, 50.3, 50.1, 27.6 ppm; IR (thin film) v 3528, 2937, 2100, 1613, 1514, 1377, 1247, 1178, 1035, 969 $\mathrm{cm}^{-1}$; HRMS (ES $\left.{ }^{+}\right)$calcd for $\mathrm{C}_{15} \mathrm{H}_{20} \mathrm{~N}_{4} \mathrm{O}_{5} \mathrm{~S} 368.1154$ found $391.1052\left(\mathrm{MNa}^{+}\right)$. 


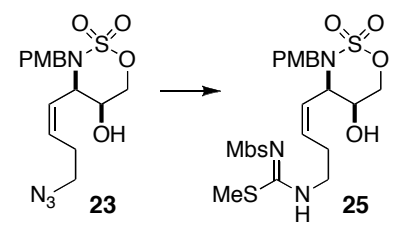

To a solution of azide $23(7.00 \mathrm{~g}, 20.0 \mathrm{mmol})$ in $120 \mathrm{~mL}$ of a $5: 1 \mathrm{THF} / \mathrm{H}_{2} \mathrm{O}$ mixture was added a $1.0 \mathrm{M}$ toluene solution of $\mathrm{Me}_{3} \mathrm{P}(40.0 \mathrm{~mL}, 40.0 \mathrm{mmol}, 2.0$ equiv). The biphasic mixture was stirred for $9 \mathrm{~h}$ then concentrated under reduced pressure. The non-viscous, oily material was allowed to stand under high vacuum $(\sim 0.1 \mathrm{~mm} \mathrm{Hg})$ for 70 min. The resulting thick oil was dissolved in $300 \mathrm{~mL}$ of $\mathrm{MeCN}$, and the solution was cooled to $0{ }^{\circ} \mathrm{C}$ before ${ }^{i} \operatorname{Pr}_{2} \mathrm{NEt}$ ( $5.05 \mathrm{~mL}, 29.0 \mathrm{mmol}, 1.45$ equiv) was added. To this mixture was then added dropwise via cannula over 5 minutes a solution of [(4-methoxyphenyl)sulfonyl]-carbonochloridimidothioic acid methyl ester in $50 \mathrm{~mL}$ of $\mathrm{MeCN}$. Transfer of the sulfonamide reagent was made quantitative with an additional $5 \mathrm{~mL}$ of MeCN. This mixture was stirred for $70 \mathrm{~min}$ at $23{ }^{\circ} \mathrm{C}$ then concentrated under reduced pressure. Purification of the oily residue by chromatography on silica gel (gradient elution: 2:1:0.3 $\rightarrow 3: 1: 0.5 \mathrm{EtOAc} /$ hexanes $/ \mathrm{CH}_{2} \mathrm{Cl}_{2}$ ) afforded the isothiourea 25 as a white foam $\left(8.40 \mathrm{~g}, 72 \%\right.$ over 2 steps): $\mathrm{TLC} \mathrm{R}_{f}=0.43\left(1: 2\right.$ hexanes/EtOAc); ${ }^{1} \mathrm{H}$ NMR $\left(\mathrm{CDCl}_{3}, 500 \mathrm{MHz}\right) \delta$ 7.95 (br s, 1H), 7.81-7.78 (m, 2H), 7.25-7.22 (m, 2H), 6.96-6.93 (m, 2H), 6.85-6.82 (m, 2H), $6.01(\mathrm{dd}, 1 \mathrm{H}, J=10.7$, $9.5 \mathrm{~Hz}), 5.70-5.65(\mathrm{~m}, 1 \mathrm{H}), 4.70(\mathrm{dd}, 1 \mathrm{H}, J=11.8,2.4 \mathrm{~Hz}), 4.61(\mathrm{dd}, 1 \mathrm{H}, J=9.0,2.3 \mathrm{~Hz}), 4.50(\mathrm{dd}, 1 \mathrm{H}, J=12.0$, $4.6 \mathrm{~Hz}), 4.42(\mathrm{~d}, 1 \mathrm{H}, J=15.5 \mathrm{~Hz}), 4.36(\mathrm{~d}, 1 \mathrm{H}, J=15.6 \mathrm{~Hz}), 3.97-3.94(\mathrm{br} \mathrm{m}, 1 \mathrm{H}), 3.85(\mathrm{~s}, 3 \mathrm{H}), 3.78(\mathrm{~s}, 3 \mathrm{H}), 3.33$ (ddd, $1 \mathrm{H}, J=13.2,10.8,5.6 \mathrm{~Hz}), 3.20-3.14(\mathrm{~m}, 1 \mathrm{H}), 2.95(\mathrm{br} \mathrm{d}, 1 \mathrm{H}, J=6.0 \mathrm{~Hz}), 2.39-2.28(\mathrm{~m}, 1 \mathrm{H}), 2.35(\mathrm{~s}, 3 \mathrm{H})$, 2.13-2.09 (m, 1H) ppm; ${ }^{13} \mathrm{C}$ NMR $\left(\mathrm{CDCl}_{3}, 125 \mathrm{MHz}\right) \delta 169.1,162.6,159.1,134.0,132.8,129.5,129.0,128.1$, 126.4, 113.9, 113.8, 75.2, 64.0, 58.5, 55.6, 55.3, 50.6, 42.9, 27.6, $14.2 \mathrm{ppm}$; IR (thin film) v 3453, 3301, 2936, 1571, 1513, 1498, 1376, 1258, 1180, 1137, 1079, 1031, $970 \mathrm{~cm}^{-1}$; HRMS (ES ${ }^{+}$) calcd for $\mathrm{C}_{24} \mathrm{H}_{31} \mathrm{~N}_{3} \mathrm{O}_{8} \mathrm{~S}_{3} 585.1237$ found $608.1185\left(\mathrm{MNa}^{+}\right)$.

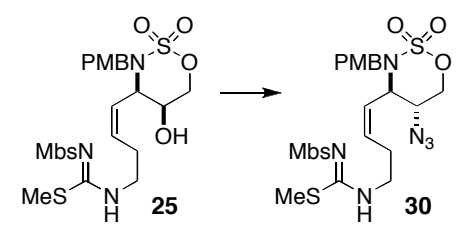

A solution of trifluoromethanesulfonic anhydride (12.3 g, $43.6 \mathrm{mmol}, 3.0$ equiv) in $20 \mathrm{~mL}$ of $\mathrm{CH}_{2} \mathrm{Cl}_{2}$ was added dropwise over $10 \mathrm{~min}$ to an ice-cold mixture of alcohol $25(8.30 \mathrm{~g}, 14.2 \mathrm{mmol})$, pyridine $(9.20 \mathrm{~mL}, 118.9 \mathrm{mmol}, 8.4$ equiv), and DMAP (440 mg, $3.60 \mathrm{mmol}, 0.25$ equiv) in $60 \mathrm{~mL}$ of $\mathrm{CH}_{2} \mathrm{Cl}_{2}$. The yellow solution was stirred for 30 min at $23{ }^{\circ} \mathrm{C}$ then loaded directly onto a column of silica gel $(60 \mathrm{~mm}$ x $200 \mathrm{~mm})$, pre-packed in 1:1 hexanes/EtOAc, and the product was eluted with 1:1 hexanes/EtOAc. The collected fractions were concentrated under reduced pressure to give an orange foam. The product was dissolved in $50 \mathrm{~mL}$ of DMF, cooled to $-15{ }^{\circ} \mathrm{C}$ in an ice $/ \mathrm{MeOH}$ bath, and $\mathrm{NaN}_{3}(4.14 \mathrm{~g}, 63.7 \mathrm{mmol}, 5.0$ equiv) was added in a single portion. The reaction mixture was stirred for $80 \mathrm{~min}$ at this temperature then poured into a separatory funnel containing $200 \mathrm{~mL}$ of $\mathrm{Et}_{2} \mathrm{O}, 100 \mathrm{~mL}$ of EtOAc and $200 \mathrm{~mL}$ of $\mathrm{H}_{2} \mathrm{O}$. The organic phase was collected, and the aqueous phase was extracted with $2 \times 150 \mathrm{~mL}$ of 1:1 $\mathrm{Et}_{2} \mathrm{O} / \mathrm{EtOAc}$ and $1 \times 100 \mathrm{~mL}$ of EtOAc. The combined organic extracts were washed successively with $2 \times 75 \mathrm{~mL}$ of $\mathrm{H}_{2} \mathrm{O}$ and $1 \times 75 \mathrm{~mL}$ of saturated aqueous $\mathrm{NaCl}$, dried over $\mathrm{MgSO}_{4}$, and concentrated under reduced pressure. Purification of the oily residue by chromatography on silica gel (gradient elution: 11:9 $\rightarrow 9: 11$ hexanes/EtOAc) afforded the azide 30 as a pale yellow foam $(5.90 \mathrm{~g}, 68 \%$ over 2 steps $)$ : TLC $\mathrm{R}_{f}=0.33\left(1: 1\right.$ hexanes/EtOAc); $[\alpha]_{\mathrm{D}}$ $+93.5^{\circ}\left(\mathrm{c}=2.00, \mathrm{CHCl}_{3}\right) ;{ }^{1} \mathrm{H}$ NMR $\left(\mathrm{CDCl}_{3}, 500 \mathrm{MHz}\right) \delta 8.10-8.05($ br m, $1 \mathrm{H}), 7.85-7.82(\mathrm{~m}, 2 \mathrm{H}), 7.31-7.28(\mathrm{~m}$, 2H), 6.98-6.95 (m, 2H), 6.92-6.89 (m, 2H), 6.05 (dd, 1H, $J=10.9,10.0 \mathrm{~Hz}), 5.71$ (dddd, $1 \mathrm{H}, J=10.9,8.7,6.6,1.0$ $\mathrm{Hz}$ ), $4.86(\mathrm{dd}, 1 \mathrm{H}, J=12.3,2.9 \mathrm{~Hz}), 6.88(\mathrm{~d}, 1 \mathrm{H}, J=14.4 \mathrm{~Hz}), 4.53$ (ddd, $1 \mathrm{H}, J=12.4,4.8,1.3 \mathrm{~Hz}), 4.30$ (dd, $1 \mathrm{H}, J$ $=9.6,4.6 \mathrm{~Hz}), 4.21(\mathrm{~d}, 1 \mathrm{H}, J=14.4 \mathrm{~Hz}), 3.88(\mathrm{~s}, 3 \mathrm{H}), 3.83(\mathrm{~s}, 3 \mathrm{H}), 3.54(\mathrm{ddd}, 1 \mathrm{H}, J=4.6,4.6,2.9 \mathrm{~Hz}), 3.33-3.27$ $(\mathrm{m}, 1 \mathrm{H}), 3.25-3.20(\mathrm{~m}, 1 \mathrm{H}), 2.36(\mathrm{~s}, 3 \mathrm{H}), 2.21-2.07(\mathrm{~m}, 2 \mathrm{H}) \mathrm{ppm} ;{ }^{13} \mathrm{C} \mathrm{NMR}\left(\mathrm{CDCl}_{3}, 125 \mathrm{MHz}\right) \delta 168.8,162.5$, 159.6, 134.2, 132.7, 130.3, 130.2, 128.2, 126.6, 114.1, 113.9, 71.2, 58.3, 56.1, 55.6, 55.3, 50.8, 42.8, 27.3, 14.1 ppm; IR (thin film) $v$ 3299, 2933, 2112, 1573, 1513, 1367, 1307, 1258, 1175, 1139, 1079, 1028, $834 \mathrm{~cm}^{-1}$; HRMS $\left(\mathrm{ES}^{+}\right)$calcd for $\mathrm{C}_{24} \mathrm{H}_{30} \mathrm{~N}_{6} \mathrm{O}_{7} \mathrm{~S}_{3} 610.1338$ found 633.1226 . 


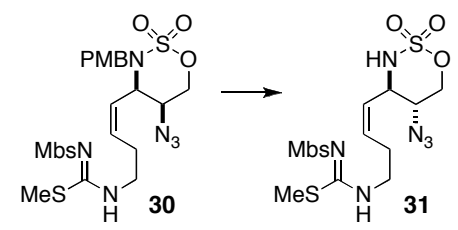

Azide 30 (2.03 g, $3.32 \mathrm{mmol})$ and ceric ammonium nitrate $(9.11 \mathrm{~g}, 16.6 \mathrm{mmol}, 5.0$ equiv) were combined in $25 \mathrm{~mL}$ of a $4: 1{ }^{t} \mathrm{BuOH} / \mathrm{CH}_{2} \mathrm{Cl}_{2}$ mixture, and the resulting orange suspension was warmed to $55{ }^{\circ} \mathrm{C}$. After stirring at this temperature for $8 \mathrm{~h}$, the reaction mixture was diluted with $150 \mathrm{~mL}$ of EtOAc and poured into a separatory funnel containing $100 \mathrm{~mL}$ of a 1/2-saturated aqueous $\mathrm{NaCl}$ solution. The organic layer was collected, and the aqueous layer was extracted with 1 x $70 \mathrm{~mL}$ of EtOAc. The combined organic extracts were washed with $1 \mathrm{x} 100 \mathrm{~mL}$ of saturated aqueous $\mathrm{NaCl}$, dried over $\mathrm{MgSO}_{4}$, and concentrated under reduced pressure. Purification of the oily residue by chromatography on silica gel $\left(9: 1 \mathrm{CH}_{2} \mathrm{Cl}_{2} / \mathrm{EtOAc}\right)$ afforded the desired product $\mathbf{3 1}$ as a pale yellow foam $(1.20 \mathrm{~g}, 74 \%)$ : TLC R $\mathrm{R}_{f}=0.42\left(9: 1 \mathrm{CH}_{2} \mathrm{Cl}_{2} / \mathrm{EtOAc}\right) ;{ }^{1} \mathrm{H} \mathrm{NMR}\left(\mathrm{CDCl}_{3}, 500 \mathrm{MHz}\right) \delta 7.91-7.88(\mathrm{~m}, 2 \mathrm{H}), 7.87(\mathrm{br} \mathrm{s}$, $1 \mathrm{H}), 6.99-6.96(\mathrm{~m}, 2 \mathrm{H}), 5.87-5.82(\mathrm{~m}, 1 \mathrm{H}), 5.69(\mathrm{t}, 1 \mathrm{H}, J=9.5 \mathrm{~Hz}), 5.52(\mathrm{~d}, 1 \mathrm{H}, J=7.8 \mathrm{~Hz}), 4.57(\mathrm{dd}, 1 \mathrm{H}, J=11.6$, $5.1 \mathrm{~Hz}), 4.49(\mathrm{dd}, 1 \mathrm{H}, J=11.6,10.4 \mathrm{~Hz}), 4.39(\mathrm{q}, 1 \mathrm{H}, J=8.5 \mathrm{~Hz}), 3.90(\mathrm{~s}, 3 \mathrm{H}), 3.68(\mathrm{ddd}, 1 \mathrm{H}, J=10.2,10.2,5.3)$, 3.60-3.54 (m, 1H), 3.35-3.31 (m, 1H), 2.86-2.78 (m, 1H), 2.42-2.38 (m, 1H), $2.40(\mathrm{~s}, 3 \mathrm{H}) \mathrm{ppm} ;{ }^{13} \mathrm{C} \mathrm{NMR}\left(\mathrm{CDCl}_{3}\right.$, $125 \mathrm{MHz}) \delta 169.3,162.6,133.9,128.3,128.2,127.4,113.9,71.0,56.3,55.6,55.5,42.9,27.7,14.1 \mathrm{ppm}$; IR (thin

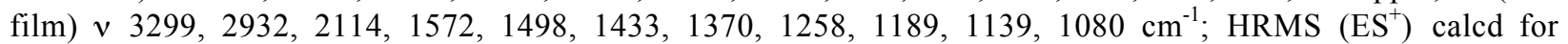
$\mathrm{C}_{16} \mathrm{H}_{22} \mathrm{~N}_{6} \mathrm{O}_{6} \mathrm{~S}_{3} 490.0763$ found 513.0661( $\left.\mathrm{MNa}^{+}\right)$.

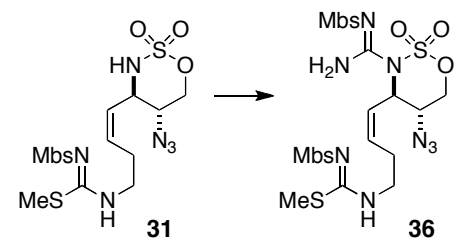

A solution of oxathiazinane $31(570 \mathrm{mg}, 1.16 \mathrm{mmol})$ in $2.5 \mathrm{~mL}$ of $\mathrm{CH}_{2} \mathrm{Cl}_{2}$ was added to a suspension of $\mathrm{NaO}{ }^{t} \mathrm{Bu}$ (125 mg, $1.30 \mathrm{mmol}, 1.1$ equiv) in $2 \mathrm{~mL}$ of $\mathrm{CH}_{2} \mathrm{Cl}_{2}$ at $0{ }^{\circ} \mathrm{C}$. The mixture was stirred for 20 min then the flask was quickly unstoppered and solid [(4-Methoxyphenyl)sulfonyl]carbonimidic dichloride (467 mg, $1.74 \mathrm{mmol}, 1.5 \mathrm{equiv}$ ) was added in a single portion. The colorless solution was stirred for $1 \mathrm{~h}$ before neat $\left(\mathrm{Me}_{3} \mathrm{Si}\right)_{2} \mathrm{NH}(1.40 \mathrm{~mL}, 6.64$ mmol, 5.7 equiv) was added dropwise; stirring was continued at $0{ }^{\circ} \mathrm{C}$ for $1.75 \mathrm{~h}$. The reaction mixture was diluted with $75 \mathrm{~mL}$ of EtOAc and poured into a separatory funnel containing $50 \mathrm{~mL}$ of saturated aqueous $\mathrm{NH}_{4} \mathrm{Cl}$. The organic phase was collected, washed with 1 x $50 \mathrm{~mL}$ of saturated aqueous $\mathrm{NaCl}$, dried over $\mathrm{MgSO}_{4}$, and concentrated under reduced pressure. Purification of the oily residue by chromatography on silica gel (gradient elution: 11:9:2 $\rightarrow$ 3:2:0 EtOAc/hexanes $\left./ \mathrm{CH}_{2} \mathrm{Cl}_{2}\right)$ afforded guanidine 36 as a white foam $(560 \mathrm{mg}, 69 \%$, note: the product 36 is not stable to prolonged storage). Unreacted starting oxathiazinane 31 was also recovered (110 mg, 20\%): $\mathrm{TLC} \mathrm{R}_{f}=0.37\left(2: 3\right.$ hexanes/EtOAc); $[\alpha]_{\mathrm{D}}+71.0^{\circ}\left(\mathrm{c}=3.40, \mathrm{CHCl}_{3}\right) ;{ }^{1} \mathrm{H} \mathrm{NMR}\left(\mathrm{CDCl}_{3}, 500 \mathrm{MHz}\right) \delta 8.04(\mathrm{br} \mathrm{s}$, $1 \mathrm{H}), 7.88-7.82(\mathrm{~m}, 4 \mathrm{H}), 7.00-6.95(\mathrm{~m}, 4 \mathrm{H}), 6.04(\mathrm{t}, 1 \mathrm{H}, J=10.4 \mathrm{~Hz}), 5.99-5.93(\mathrm{~m}, 1 \mathrm{H}), 5.70-5.64(\mathrm{~m}, 1 \mathrm{H}), 5.04(\mathrm{dd}$, $1 \mathrm{H}, J=12.2,1.6 \mathrm{~Hz}), 4.60(\mathrm{dq}, 1 \mathrm{H}, J=12.3,1.7 \mathrm{~Hz}), 3.99(\mathrm{br} \mathrm{d}, 1 \mathrm{H}, J=2.3 \mathrm{~Hz}), 3.88(\mathrm{~s} 3 \mathrm{H}), 3.87$ (s, 3H), 3.50$3.45(\mathrm{~m}, 1 \mathrm{H}), 3.31-3.25(\mathrm{~m}, 1 \mathrm{H}), 2.72-2.64(\mathrm{~m}, 1 \mathrm{H}), 2.39-2.33(\mathrm{~m}, 1 \mathrm{H}), 2.38(\mathrm{~s}, 3 \mathrm{H}) \mathrm{ppm} ;{ }^{13} \mathrm{C} \mathrm{NMR}\left(\mathrm{CDCl}_{3}, 125\right.$ $\mathrm{MHz}) \delta 168.9,162.8,162.5,151.9,134.1,133.7,130.3,128.3,128.2,125.3,114.0,113.9,73.2,57.5,56.2,55.6$, 55.5, 42.8, 27.8, $14.1 \mathrm{ppm}$; IR (thin film) v 3447, 3317, 2945, 2114, 1626, 1596, 1577, 1499, 1419, 1310, 1260, $1192,1141,1078,1025 \mathrm{~cm}^{-1}$.

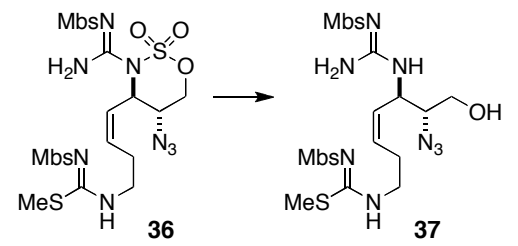

Guanidine 36 was dissolved in a mixture of $11: 2 \mathrm{MeCN} / \mathrm{H}_{2} \mathrm{O}$, and the solution was stirred at $70{ }^{\circ} \mathrm{C}$ for $5 \mathrm{~h}$. After this time, all volatiles were removed by concentration under reduced pressure. The isolated material was left to stand under vacuum $(\sim 0.1 \mathrm{~mm} \mathrm{Hg})$ for $1 \mathrm{~h}$. Purification of the oily residue by chromatography on silica gel (10:5:1 
EtOAc/ $\mathrm{CH}_{2} \mathrm{Cl}_{2} / \mathrm{MeOH}$ ) afforded alcohol 37 as a white foam (450 mg, 92\%): TLC $\mathrm{R}_{f}=0.36$ (2:7 hexanes/EtOAc); $[\alpha]_{\mathrm{D}}-103.3^{\circ}\left(\mathrm{c}=2.20, \mathrm{CHCl}_{3}\right) ;{ }^{1} \mathrm{H} \mathrm{NMR}\left(\mathrm{CDCl}_{3}, 500 \mathrm{MHz}\right) \delta$ 7.87-7.84 (m, 4H), $7.78(\mathrm{br} \mathrm{s}, 1 \mathrm{H}), 6.98-6.93(\mathrm{~m}, 4 \mathrm{H})$, $6.70(\mathrm{br} \mathrm{s}, 2 \mathrm{H}), 5.97(\mathrm{br} \mathrm{s}, 1 \mathrm{H}), 5.71(\mathrm{t}, 1 \mathrm{H}, J=9.3 \mathrm{~Hz}), 5.61-5.56(\mathrm{~m}, 1 \mathrm{H}), 4.79-4.76(\mathrm{br} \mathrm{m}, 1 \mathrm{H}), 3.87(\mathrm{~s}, 3 \mathrm{H}), 3.85$ $(\mathrm{s}, 3 \mathrm{H}), 3.73(\mathrm{br} \mathrm{s}, 2 \mathrm{H}), 3.40(\mathrm{br} \mathrm{s}, 1 \mathrm{H}), 3.27-3.22(\mathrm{~m}, 2 \mathrm{H}), 2.36(\mathrm{~s}, 3 \mathrm{H}), 2.26-2.22(\mathrm{~m}, 2 \mathrm{H}) \mathrm{ppm} ;{ }^{13} \mathrm{C} \mathrm{NMR}\left(\mathrm{CDCl}_{3}\right.$, $125 \mathrm{MHz}) \delta 169.5,162.7,162.3,155.8,134.9,133.5,132.0,129.8,128.1,128.0,114.0,113.8,65.4,61.3,55.6$, 55.5, 47.3, 43.0, 27.5, $14.2 \mathrm{ppm}$; IR (thin film) v 3444, 3338, 2944, 2103, 1596, 1577, 1533, 1499, 1258, 1133, $1083,833 \mathrm{~cm}^{-1}$; HRMS (ES $\left.{ }^{+}\right)$calcd for $\mathrm{C}_{24} \mathrm{H}_{32} \mathrm{~N}_{8} \mathrm{O}_{7} \mathrm{~S}_{3} 640.1556$ found $663.1437\left(\mathrm{MNa}^{+}\right)$.

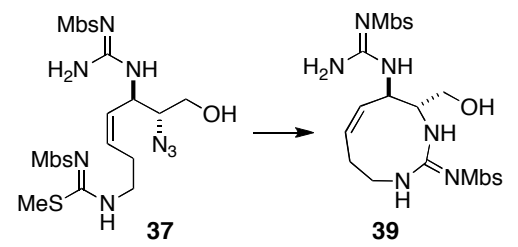

To a solution of alcohol $37(440 \mathrm{mg}, 0.688 \mathrm{mmol})$ in $9.6 \mathrm{~mL}$ of a $5: 1 \mathrm{THF} / \mathrm{H}_{2} \mathrm{O}$ mixture was added dropwise a $1.0 \mathrm{M}$ toluene solution of $\mathrm{PMe}_{3}(3.30 \mathrm{~mL}, 3.30 \mathrm{mmol}, 4.8$ equiv). The biphasic mixture was stirred for $23 \mathrm{~h}$ then transferred to a separatory funnel containing $50 \mathrm{~mL}$ of saturated aqueous $\mathrm{NaHCO}_{3}$ with $80 \mathrm{~mL}$ of EtOAc. The organic layer was collected and the aqueous layer was extracted with 1 x $50 \mathrm{~mL}$ of EtOAc. The combined organic extracts were washed with $50 \mathrm{~mL}$ of saturated aqueous $\mathrm{NaCl}$, dried over $\mathrm{MgSO}_{4}$, and concentrated to a white solid. This material was dissolved in $80 \mathrm{~mL}$ of $\mathrm{MeCN}$ and added dropwise via syringe over 45 min to a solution of $\mathrm{AgNO}_{3}$ (135 mg, $0.795 \mathrm{mmol}, 1.3$ equiv) and $\mathrm{Et}_{3} \mathrm{~N}(850 \mu \mathrm{L}, 6.10 \mathrm{mmol}, 10.0$ equiv) in $120 \mathrm{~mL}$ of $\mathrm{MeCN}$ (note: the reaction vessel containing $\mathrm{AgNO}_{3}$ was wrapped in aluminum foil to prevent exposure to light). The transfer was made quantitative with two $10 \mathrm{~mL}$ portions of $\mathrm{MeCN}$. After stirring for an additional $20 \mathrm{~min}$, the contents were filtered through a small pad of Celite using $\sim 400 \mathrm{~mL}$ of $\mathrm{CH}_{2} \mathrm{Cl}_{2}$ to rinse the flask and filter cake. The combined filtrates were concentrated under reduced pressure to a light brown solid. Purification by chromatography on silica gel (97:3 $\left.\mathrm{CH}_{2} \mathrm{Cl}_{2} / \mathrm{MeOH}\right)$ afforded the desired product 39 as a white solid $\left(220 \mathrm{mg}, 64 \%\right.$ over two steps): TLC $\mathrm{R}_{f}=0.28$ $\left(20: 1 \mathrm{CH}_{2} \mathrm{Cl}_{2} / \mathrm{MeOH}\right) ; \mathrm{mp} 147-150{ }^{\circ} \mathrm{C} ;[\alpha]_{\mathrm{D}}+91.0^{\circ}(\mathrm{c}=2.60, \mathrm{MeOH}) ;{ }^{1} \mathrm{H} \mathrm{NMR}\left(\mathrm{CD}_{3} \mathrm{CN}, 500 \mathrm{MHz}, 70{ }^{\circ} \mathrm{C}\right) \delta 7.81-$ $7.75(\mathrm{~m}, 4 \mathrm{H}), 7.07-7.01(\mathrm{~m}, 4 \mathrm{H}), 6.73(\mathrm{br} \mathrm{s}, 1 \mathrm{H}), 6.25(\mathrm{br} \mathrm{s}, 2 \mathrm{H}), 5.76(\mathrm{br} \mathrm{s}, 1 \mathrm{H}), 5.00(\mathrm{br} \mathrm{s}, 1 \mathrm{H}), 4.87-4.83(\mathrm{~m}, 1 \mathrm{H})$, 4.69 (t, $1 \mathrm{H}, J=10.0 \mathrm{~Hz}$ ), 3.97-3.87 (br m, 1H), 3.90 (s, 3H), 3.89 (s, 3H), 3.78 (br d, 1H, $J=11.7$ ), 3.68 (br d, $1 \mathrm{H}, J$ $=11.9 \mathrm{~Hz}), 3.51-3.43(\mathrm{~m}, 2 \mathrm{H}), 3.27(\mathrm{br} \mathrm{s}, 1 \mathrm{H}), 2.49(\mathrm{br} \mathrm{s}, 1 \mathrm{H}) 2.04-2.00(\mathrm{br} \mathrm{m}, 1 \mathrm{H}) \mathrm{ppm}$; IR (KBr pellet) v 3335, 2943, 1597, 1531, 1499, 1257, 1131, 1080, $834 \mathrm{~cm}^{-1}$; HRMS $\left(\mathrm{ES}^{+}\right)$calcd for $\mathrm{C}_{23} \mathrm{H}_{30} \mathrm{~N}_{6} \mathrm{O}_{7} \mathrm{~S}_{2} 566.1617$ found $589.1503\left(\mathrm{MNa}^{+}\right)$.

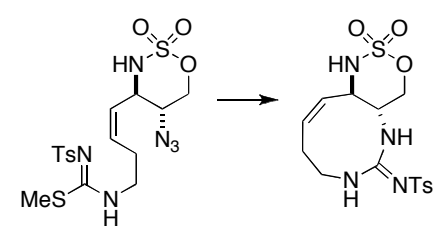

Azide (205 mg, $0.43 \mathrm{mmol}$ ) was dissolved in $10 \mathrm{~mL}$ of a $6: 1$ mixture of THF/MeOH and to this solution was added $\mathrm{SnCl}_{2}$ (115 mg, $0.61 \mathrm{mmol}, 1.4$ equiv). The resulting pale yellow mixture was stirred for $6.5 \mathrm{~h}$, after which time the reaction mixture was poured into a separatory funnel containing $50 \mathrm{~mL}$ of EtOAc and $25 \mathrm{~mL}$ of pH 6 aqueous $\mathrm{NaOH}$. The organic phase was collected; the aqueous layer was adjusted to $\mathrm{pH} 9$ by the addition of $1 \mathrm{M} \mathrm{NaOH}$ and extracted with $2 \times 20 \mathrm{~mL}$ of EtOAc. The combined organic fractions were washed with $20 \mathrm{~mL}$ of saturated aqueous $\mathrm{NaCl}$, dried over $\mathrm{MgSO}_{4}$ and concentrated under reduced pressure to an oily residue. This material was re-dissolved in $50 \mathrm{~mL}$ of $\mathrm{MeCN}$ and $6 \mathrm{~mL}$ of $\mathrm{CH}_{2} \mathrm{Cl}_{2}$ and was added dropwise over 40 min to a solution of $\mathrm{AgNO}_{3}(95 \mathrm{mg}, 0.56$ mmol, 1.3 equiv), and $\mathrm{Et}_{3} \mathrm{~N}$ (598 $\mu \mathrm{L}, 4.30 \mathrm{mmol}, 10$ equiv) in $65 \mathrm{~mL}$ of $\mathrm{MeCN}$ (note: the reaction vessel containing $\mathrm{AgNO}_{3}$ was wrapped in aluminium foil to prevent exposure to light). The transfer of amine substrate was made quantitative with $15 \mathrm{~mL}$ of $2: 1 \mathrm{MeCN} / \mathrm{CH}_{2} \mathrm{Cl}_{2}$. After stirring for an additional $20 \mathrm{~min}$, the contents were filtered through a small pad of Celite using $\sim 150 \mathrm{~mL}$ of $\mathrm{CH}_{2} \mathrm{Cl}_{2}$ to rinse the flask and filter cake. The combined filtrates were concentrated under reduced pressure to a beige solid. Purification by chromatograpy on silica gel (8:12:1 $\left.\mathrm{CH}_{2} \mathrm{Cl}_{2} / \mathrm{EtOAc} / \mathrm{MeCN}\right)$ gave the bicyclic product as a white solid $(78 \mathrm{mg}, 40 \%)$. TLC $\mathrm{R}_{f}=0.38(2: 3$ $\left.\mathrm{CH}_{2} \mathrm{Cl}_{2} / \mathrm{EtOAc}\right) ;{ }^{1} \mathrm{H}$ NMR $\left(\mathrm{CDCl}_{3}+10 \% \mathrm{CD}_{3} \mathrm{CN}, 500 \mathrm{MHz}\right) \delta 7.70(\mathrm{~d}, 2 \mathrm{H}, J=8.5 \mathrm{~Hz}), 7.25(\mathrm{~d}, 2 \mathrm{H}, J=8.5 \mathrm{~Hz})$, 7.16 (br s, 1H), 5.46 (d, 1H, $J=10.5 \mathrm{~Hz}), 4.76($ br s, $1 \mathrm{H}), 4.65-4.54$ (m, 3H), 4.47 (dd, $1 \mathrm{H}, J=8.7,4.9 \mathrm{~Hz}), 4.37$ - 
$4.29(\mathrm{~m}, 1 \mathrm{H}), 4.05-3.95(\mathrm{~m}, 1 \mathrm{H}), 3.46-3.38(\mathrm{~m}, 1 \mathrm{H}), 3.38-3.30(\mathrm{~m}, 1 \mathrm{H}), 2.86-2.74(\mathrm{~m}, 1 \mathrm{H}), 2.38(\mathrm{~s}, 3 \mathrm{H}), 2.21-2.16$ $(\mathrm{m}, 1 \mathrm{H})$.

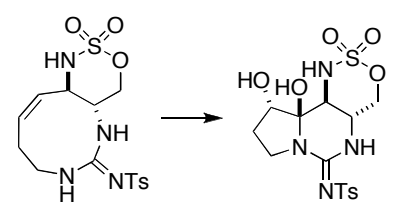

A $0.01 \mathrm{M}$ aqueous solution of $\mathrm{RuCl}_{3}\left(46 \mu \mathrm{L}, 0.46 \mu \mathrm{mol}, 0.02\right.$ equiv) was added to an ice cold mixture of $\mathrm{NaIO}_{4}(7.5$ $\mathrm{mg}, 0.035 \mathrm{mmol}, 1.5$ equiv) and $1.5 \mathrm{M}$ aqueous $\mathrm{H}_{2} \mathrm{SO}_{4}(75 \mu \mathrm{L}, 0.11 \mathrm{mmol}, 5.0$ equiv) in $100 \mu \mathrm{L}$ of $1: 1$ $\mathrm{MeCN} /$ EtOAc. A solution of the starting alkene $(10 \mathrm{mg}, 0.023 \mathrm{mmol})$ in $300 \mu \mathrm{L}$ of $1: 1 \mathrm{MeCN} / \mathrm{EtOAc}$ was added via cannula. The transfer of this material was made quantitative with an additional $200 \mu \mathrm{L}$ of $1: 1 \mathrm{MeCN} / \mathrm{EtOAc}$. After stirring for $2 \mathrm{~h}$ at $0{ }^{\circ} \mathrm{C}$, the pale yellow solution was warmed to $23{ }^{\circ} \mathrm{C}$ and stirred for an additional $2 \mathrm{~h}$. The reaction was quenched by the successive addition of $1 \mathrm{~mL}$ of saturated aqueous $\mathrm{Na}_{2} \mathrm{~S}_{2} \mathrm{O}_{3}$ and $1 \mathrm{~mL}$ of saturated aqueous $\mathrm{NaHCO}_{3}$. The contents were diluted with $20 \mathrm{~mL}$ of EtOAc and poured into a separatory funnel containing $5 \mathrm{~mL}$ of $\mathrm{H}_{2} \mathrm{O}$. The organic phase was collected, and the aqueous layer was extracted with $2 \times 10 \mathrm{~mL}$ of EtOAc. The combined organic extracts were washed with $1 \times 10 \mathrm{~mL}$ of saturared aqueous $\mathrm{NaCl}$, dried over $\mathrm{MgSO}_{4}$, and concentrated under reduced pressure. Purification of the solid residue by chromatography on silica gel (4:6:1 $\left.\mathrm{CH}_{2} \mathrm{Cl}_{2} / \mathrm{EtOAc} / \mathrm{MeCN}\right)$ gave the tricyclic hemi-aminal as a white solid $(3.5 \mathrm{mg}, 35 \%)$; TLC $\mathrm{R}_{f}=0.28(4: 6: 1$ $\left.\mathrm{CH}_{2} \mathrm{Cl}_{2} / \mathrm{EtOAc} / \mathrm{MeCN}\right) ;{ }^{1} \mathrm{H}$ NMR $\left(\mathrm{CD}_{3} \mathrm{CN}, 500 \mathrm{MHz}\right) \delta 7.75(\mathrm{~m}, 2 \mathrm{H}), 7.62(\mathrm{~s}, 1 \mathrm{H}), 7.35(\mathrm{~m}, 2 \mathrm{H}), 5.58(\mathrm{~d}, 1 \mathrm{H}, J=$ $11.1 \mathrm{~Hz}), 4.83(\mathrm{dd}, 1 \mathrm{H}, J=10.7,4.6 \mathrm{~Hz}), 4.55(\mathrm{~s}, 1 \mathrm{H}), 4.48(\mathrm{dd}, 1 \mathrm{H}, J=10.6,10.6 \mathrm{~Hz}), 4.12(\mathrm{dd}, 1 \mathrm{H}, J=4.3,4.3$ $\mathrm{Hz}), 3.90$ (dd, $1 \mathrm{H}, J=11.2,11.2 \mathrm{~Hz}), 3.82(\mathrm{ddd}, 1 \mathrm{H} . J=10.9,10.9,4.5 \mathrm{~Hz}), 3.62-3.55(\mathrm{~m}, 3 \mathrm{H}), 2.45(\mathrm{~s}, 3 \mathrm{H}), 2.30$ (dddd, $1 \mathrm{H}, J=13.9,9.9,9.9,4.0 \mathrm{~Hz}$ ), 1.87 (ddd, $1 \mathrm{H}, J=13.8,7.0,2.3 \mathrm{~Hz}$ ) ppm; IR (thin film) v 3310, 2925, 1578, $1519,1382,1261,1193,1129,1077,980,860 \mathrm{~cm}^{-1}$; HRMS $\left(\mathrm{ES}^{+}\right)$calcd for $\mathrm{C}_{15} \mathrm{H}_{20} \mathrm{~N}_{4} \mathrm{O}_{7} \mathrm{~S}_{2} 432.0073$ found 455.0687 $\left(\mathrm{MNa}^{+}\right)$.

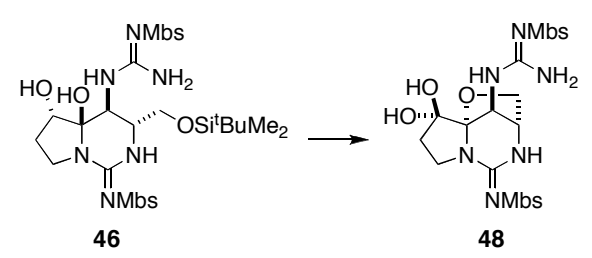

Hemi-aminal 46 (21 mg, $31 \mu \mathrm{mol})$ was dissolved in $6 \mathrm{~mL}$ of $\mathrm{CHCl}_{3}$ and to this solution was added $p$-TsOH (6 mg, $35 \mu \mathrm{mol}, 1.1$ equiv). The resulting mixture was stirred for $10 \mathrm{~h}$ then concentrated under reduced pressure. Purification of the isolated residue by chromatography on silica gel $(9: 1 \mathrm{EtOAc} / \mathrm{MeCN})$ furnished the intermediate product as a white solid $(10 \mathrm{mg})$. This material was dissolved in $600 \mu \mathrm{L}$ of a 5:1 mixture of $\mathrm{CH}_{2} \mathrm{Cl}_{2} / \mathrm{DMSO}$, to which $\mathrm{Et}_{3} \mathrm{~N}\left(28 \mu \mathrm{L}, 0.20 \mathrm{mmol}, 12\right.$ equiv) and $\mathrm{C}_{5} \mathrm{H}_{5} \mathrm{~N} \cdot \mathrm{SO}_{3}(16 \mathrm{mg}, 0.10 \mathrm{mmol}, 5.9$ equiv) were then added successively. The resulting solution was stirred for $7.5 \mathrm{~h}$ then poured into a separatory funnel containing $20 \mathrm{~mL}$ of EtOAc. The solution was washed with $10 \mathrm{~mL}$ of half-saturated aqueous $\mathrm{NH}_{4} \mathrm{Cl}$ and the organic phase was collected. The aqueous phase was extracted with $2 \times 10 \mathrm{~mL}$ of EtOAc. The combined organic portions were washed with 10 $\mathrm{mL}$ of saturated aqueous $\mathrm{NaCl}$, dried over $\mathrm{MgSO}_{4}$, and concentrated under reduced pressure. Purification of the oily residue by chromatography on silica gel $\left(20: 1 \mathrm{CH}_{2} \mathrm{Cl}_{2} / \mathrm{MeOH}\right)$ gave $\mathrm{N}, \mathrm{O}$-acetal $\mathbf{4 8}$ as a white solid $(6 \mathrm{mg}, 36 \%$ over two steps): $\quad$ TLC $\mathrm{R}_{f}=0.20(9: 1 \mathrm{EtOAc} / \mathrm{MeCN}) ;{ }^{1} \mathrm{H} \mathrm{NMR}\left(\mathrm{CD}_{3} \mathrm{CN}, 500 \mathrm{MHz}\right) \delta 7.93(\mathrm{~d}, 1 \mathrm{H}, J=4.9 \mathrm{~Hz}), 7.79-7.77$ $(\mathrm{m}, 2 \mathrm{H}), 7.71-7.69(\mathrm{~m}, 2 \mathrm{H}), 7.58(\mathrm{br} \mathrm{s}, 1 \mathrm{H}), 7.11(\mathrm{br} \mathrm{s}, 1 \mathrm{H}), 7.05-7.03(\mathrm{~m}, 2 \mathrm{H}), 7.03-7.01(\mathrm{~m}, 2 \mathrm{H}), 4.93(\mathrm{br} \mathrm{s}, 1 \mathrm{H})$, 4.34 (ddd, $1 \mathrm{H}, J=5.5,3.4,3.4 \mathrm{~Hz}), 4.26(\mathrm{dd}, 1 \mathrm{H}, J=9.5,3.4 \mathrm{~Hz}), 4.19(\mathrm{~d}, 1 \mathrm{H}, J=9.4 \mathrm{~Hz}), 3.88(\mathrm{~s}, 3 \mathrm{H}), 3.87$ (s, $3 \mathrm{H}), 3.83(\mathrm{dd}, 1 \mathrm{H}, J=3.7,0.9 \mathrm{~Hz}), 3.40(\mathrm{dd}, 1 \mathrm{H}, J=11.0,8.1 \mathrm{~Hz}), 2.64(\mathrm{ddd}, 1 \mathrm{H}, J=11.2,11.2,7.2 \mathrm{~Hz}), 2.26-2.10$ $(\mathrm{m}, 2 \mathrm{H}) \mathrm{ppm}$; IR (thin film) $v 3313,2922,1596,1566,1499,1257,1134,1081,1004,832 \mathrm{~cm}^{-1}$; HRMS (ES ${ }^{+}$calcd for $\mathrm{C}_{23} \mathrm{H}_{26} \mathrm{~N}_{6} \mathrm{O}_{8} \mathrm{~S}_{2}$ (ketone form) 578.1254 found $601.1151\left(\mathrm{MNa}^{+}\right.$). 
HMBC Correlations for $48\left(\mathrm{CD}_{3} \mathrm{CN}, 600 \mathrm{MHz}\right)$ :

Note: ${ }^{1} \mathrm{H}$ and ${ }^{13} \mathrm{C}$ NMR signals associated with the Mbs groups have been omitted from the tabulated list.

\begin{tabular}{|c|c|c|c|}
\hline & Position (STX numbering) & $\underline{{ }^{1} \mathbf{H} \text { NMR } \delta}(\mathrm{ppm})$ & ${ }^{13} \mathbf{C ~ N M R ~ \delta ~ ( p p m ) ~}$ \\
\hline & H5 & 4.32 & C4 92.2; C6 46.1 \\
\hline & H13a & 4.26 & C492.2 \\
\hline \multirow{2}{*}{ (12) } & H13b & 4.17 & C4 92.2; C5 52.2; C6 46.1 \\
\hline & H6 & 3.81 & C4 92.2 \\
\hline \multirow{4}{*}{$\begin{array}{l}\text { NMbs } \\
48\end{array}$} & $\mathrm{H} 10 \mathrm{a}$ & 3.40 & C12 86.7 \\
\hline & $\mathrm{H} 10 \mathrm{~b}$ & 2.64 & C11 35.8 \\
\hline & H11a & 2.18 & C12 86.7 \\
\hline & $\mathrm{H} 11 \mathrm{~b}$ & 2.13 & C12 86.7; C4 92.2 \\
\hline
\end{tabular}
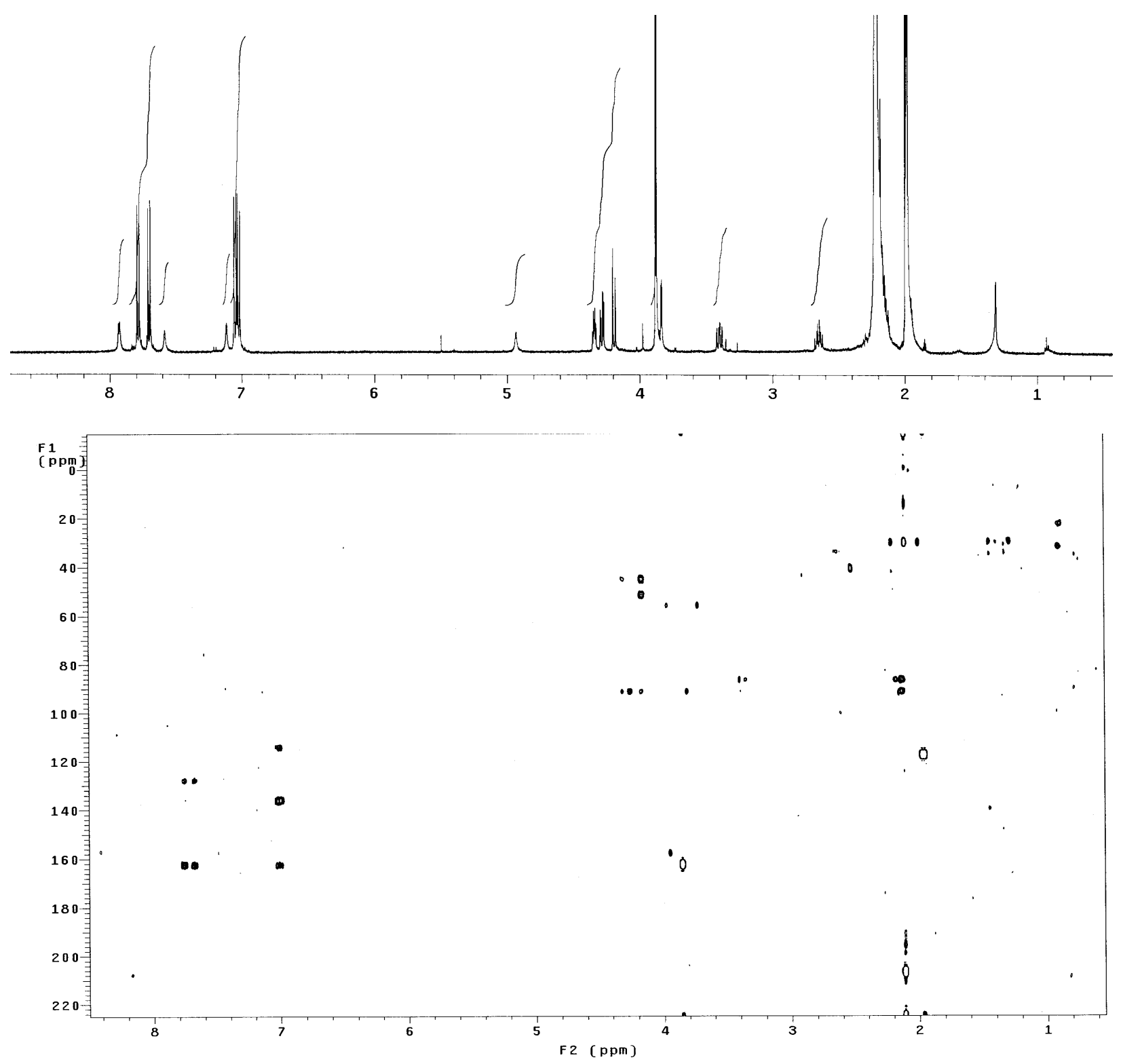


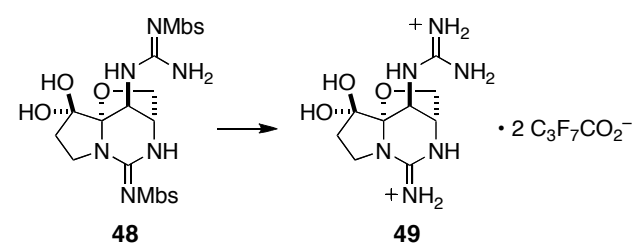

$N, O$-Acetal $48(4.0 \mathrm{mg}, 6.7 \mu \mathrm{mol})$ was dissolved in $400 \mu \mathrm{L}$ of $\mathrm{CF}_{3} \mathrm{CO}_{2} \mathrm{H}$ and to this solution was added sequentially methanesulfonic acid ( $20 \mu \mathrm{L}, 0.31 \mathrm{mmol}, 46$ equiv) and thioanisole $(5 \mu \mathrm{L}, 43 \mu \mathrm{mol}, 6$ equiv). After stirring for 28 $\mathrm{h}$, the resulting colorless mixture was concentrated under reduced pressure. A portion of the obtained residue was purified by reverse-phase HPLC (Altima C18, $5 \mu \mathrm{m}, 10 \times 250 \mathrm{~mm}$ column, eluting with a gradient flow over $30 \mathrm{~min}$ of 10:90 MeCN/10 mM aqueous $\mathrm{C}_{3} \mathrm{~F}_{7} \mathrm{CO}_{2} \mathrm{H} \rightarrow 25: 75 \mathrm{MeCN} / 10 \mathrm{mM}$ aqueous $\mathrm{C}_{3} \mathrm{~F}_{7} \mathrm{CO}_{2} \mathrm{H}, 214 \mathrm{~nm}$ UV detection). At a flow rate of $6 \mathrm{~mL} / \mathrm{min}$, the bis-guanidinium salt 49 has a retention time of $15.0 \mathrm{~min}(\sim 0.3 \mathrm{mg}$ of pure 49 was isolated): ${ }^{1} \mathrm{H}$ NMR $\left(\mathrm{D}_{2} \mathrm{O}, 500 \mathrm{MHz}\right) \delta 4.48(\mathrm{~d}, 1 \mathrm{H}, J=9.4 \mathrm{~Hz}), 4.44-4.40(\mathrm{~m}, 2 \mathrm{H}), 4.02(\mathrm{~d}, 1 \mathrm{H}, J=3.5 \mathrm{~Hz}), 3.74$ (ddd, $1 \mathrm{H}, J=10.1,6.3,3.5 \mathrm{~Hz}), 3.31-3.25(\mathrm{~m}, 1 \mathrm{H}), 2.49-2.46(\mathrm{~m}, 2 \mathrm{H})$; HRMS (ES ${ }^{+}$) calcd for $\mathrm{C}_{9} \mathrm{H}_{14} \mathrm{~N}_{6} \mathrm{O}_{2}$ (ketone form) 238.1178 found $239.1260\left(\mathrm{MH}^{+}\right)$. Note: The ${ }^{1} \mathrm{H}$ NMR spectrum of 49 shows clear differences from that of decarbamoyl STX $\cdot 2 \mathrm{Cl}^{-7}$.

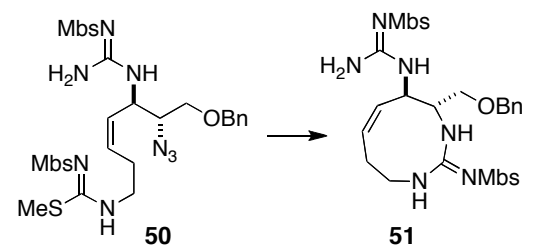

To a solution of azide $\mathbf{5 0}(260 \mathrm{mg}, 0.35 \mathrm{mmol})$ in $5.5 \mathrm{~mL}$ of $5: 1 \mathrm{THF} / \mathrm{H}_{2} \mathrm{O}$ was added dropwise a $1.0 \mathrm{M}$ toluene solution of $\mathrm{Me}_{3} \mathrm{P}(1.74 \mathrm{~mL}, 1.74 \mathrm{mmol}, 5.0$ equiv). The opaque mixture was stirred for $20 \mathrm{~h}$ then transferred to a separatory funnel containing $100 \mathrm{~mL}$ of EtOAc and $50 \mathrm{~mL}$ of saturated aqueous $\mathrm{NaHCO}_{3}$. The organic layer was isolated and the aqueous layer was extracted with $50 \mathrm{~mL}$ of EtOAc. The combined organic fractions were washed with $50 \mathrm{~mL}$ of saturated aqueous $\mathrm{NaCl}$, dried over $\mathrm{MgSO}_{4}$ and concentrated under reduced pressure. The oily residue was re-dissolved in $45 \mathrm{~mL}$ of $\mathrm{MeCN}$ and $5 \mathrm{~mL}$ of $\mathrm{CH}_{2} \mathrm{Cl}_{2}$ and this solution was added dropwise over $40 \mathrm{~min}$ to a mixture of $\mathrm{AgNO}_{3}\left(77 \mathrm{mg}, 0.45 \mathrm{mmol}, 1.3\right.$ equiv), and $\mathrm{Et}_{3} \mathrm{~N}$ ( $485 \mu \mathrm{L}, 3.48 \mathrm{mmol}, 10$ equiv) in $60 \mathrm{~mL}$ of $\mathrm{MeCN}$ (note: the reaction vessel containing $\mathrm{AgNO}_{3}$ was wrapped in aluminium foil to prevent exposure to light). Transfer of the amine substrate was made quantitative with $15 \mathrm{~mL}$ of $2: 1 \mathrm{MeCN} / \mathrm{CH}_{2} \mathrm{Cl}_{2}$. After stirring for an additional 20 min, the contents were filtered through a small pad of Celite using $\sim 150 \mathrm{~mL}$ of $\mathrm{CH}_{2} \mathrm{Cl}_{2}$ to rinse the flask and filter cake. The combined filtrates were concentrated under reduced pressure to a beige solid. Purification of the solid residue by chromatography on silica gel $\left(20: 1 \mathrm{CH}_{2} \mathrm{Cl}_{2} / \mathrm{MeOH}\right)$ gave cyclic guanidine $\mathbf{5 1}$ as a white solid (165 $\mathrm{mg}$, $72 \%$ over 2 steps): TLC $\mathrm{R}_{f}=0.20\left(20: 1 \mathrm{CH}_{2} \mathrm{Cl}_{2} / \mathrm{MeOH}\right) ;{ }^{1} \mathrm{H}$ NMR $\left(\mathrm{CD}_{3} \mathrm{CN}, 500 \mathrm{MHz}\right) \delta$ 7.80-7.77 (m, 2H), 7.76$7.73(\mathrm{~m}, 2 \mathrm{H}), 7.44-7.35(\mathrm{~m}, 5 \mathrm{H}), 7.06-7.03(\mathrm{~m}, 2 \mathrm{H}), 6.97-6.94(\mathrm{~m}, 2 \mathrm{H}), 6.57$ (br s, 1H), 6.23 (br s, 2H), 5.72 (br s, $1 \mathrm{H}), 5.17(\mathrm{br} \mathrm{s}, 1 \mathrm{H}), 4.89-4.83(\mathrm{~m}, 1 \mathrm{H}), 4.67-4.55(\mathrm{~m}, 3 \mathrm{H}), 3.90(\mathrm{~s}, 3 \mathrm{H}), 3.86(\mathrm{~s}, 3 \mathrm{H}), 3.72(\mathrm{br} \mathrm{d}, 1 \mathrm{H}, J=7.3 \mathrm{~Hz})$, 3.65 (dd, 1H, $J=9.9,2.4 \mathrm{~Hz}$ ), 3.58 (br s, 1H), 3.46-3.37 (m, 1H), 3.05 (br s, 1H), 2.42 (br s, 1H) ppm; IR (thin film) $3327,1595,1498,1309,1255,1130,1080,1026,832 \mathrm{~cm}^{-1}$; HRMS $\left(\right.$ ES $\left.^{+}\right)$calcd for $\mathrm{C}_{30} \mathrm{H}_{36} \mathrm{~N}_{6} \mathrm{O}_{7} \mathrm{~S}_{2} 656.2087$ found $679.1957\left(\mathrm{MNa}^{+}\right)$.
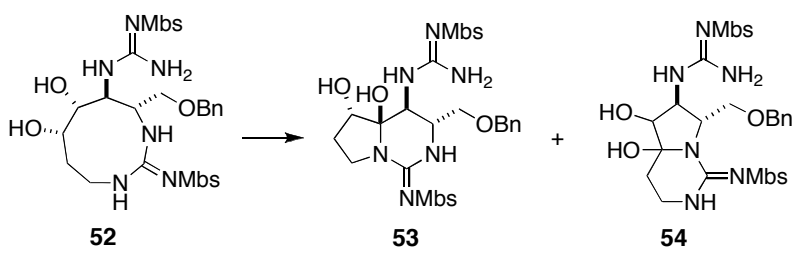

To a solution of diol $\mathbf{5 2}(41 \mathrm{mg}, 59 \mu \mathrm{mol})$ in $3 \mathrm{~mL}$ of reagent-grade $\mathrm{CH}_{2} \mathrm{Cl}_{2}$ was added Dess-Martin periodinane (39 $\mathrm{mg}, 0.092 \mathrm{mmol}, 1.5$ equiv) in a single portion. The mixture became opaque over $20 \mathrm{~min}$, and after stirring for 1.5 $\mathrm{h}$, a second portion of Dess-Martin periodinane $(10 \mathrm{mg}, 0.024 \mathrm{mmol}, 0.4$ equiv) was added. Stirring was continued for $1.5 \mathrm{~h}$ then the reaction was quenched by the addition of $1 \mathrm{~mL}$ of $20: 1 \mathrm{CH}_{2} \mathrm{Cl}_{2} / \mathrm{MeOH}$. The resulting white suspension was concentrated under reduced pressure, and the solid residue obtained was purified by chromatography 
on silica gel (gradient elution: 25:1 $\mathrm{CH}_{2} \mathrm{Cl}_{2} / \mathrm{MeOH} \rightarrow 20: 1 \mathrm{CH}_{2} \mathrm{Cl}_{2} / \mathrm{MeOH}$ ). The minor, undesired product 54 was first to elute from the column and was isolated as a white solid $(15 \mathrm{mg}, 36 \%)$. The major product $\mathbf{5 3}$ was also obtained as a white solid (26 mg, 63\%): TLC $\mathrm{R}_{f}=0.60_{\text {minor }}, 0.53_{\text {major }}\left(93: 7 \mathrm{CH}_{2} \mathrm{Cl}_{2} / \mathrm{MeOH}\right)$; Minor isomer 54: ${ }^{1} \mathrm{H}$ NMR $\left(\mathrm{CDCl}_{3}, 500 \mathrm{MHz}\right) \delta 7.78(\mathrm{~d}, 2 \mathrm{H}, J=8.9 \mathrm{~Hz}), 7.72(\mathrm{~d}, 2 \mathrm{H}, J=8.8 \mathrm{~Hz}), 7.67(\mathrm{~d}, 1 \mathrm{H}, J=4.9 \mathrm{~Hz}), 7.30-7.26(\mathrm{~m}$, $3 \mathrm{H}), 7.15-7.13(\mathrm{~m}, 2 \mathrm{H}), 6.89-6.86(\mathrm{~m}, 4 \mathrm{H}), 6.58(\mathrm{br} \mathrm{s}, 3 \mathrm{H}), 4.35(\mathrm{~d}, 1 \mathrm{H}, J=11.5 \mathrm{~Hz}), 4.31-4.26(\mathrm{~m}, 2 \mathrm{H}), 4.19$ (br s, $1 \mathrm{H}), 4.12-4.11(\mathrm{~m}, 1 \mathrm{H}), 3.82(\mathrm{~s}, 3 \mathrm{H}), 3.81(\mathrm{~s}, 3 \mathrm{H}), 3.73(\mathrm{br} \mathrm{s}, 1 \mathrm{H}), 3.67(\mathrm{dd}, 1 \mathrm{H}, J=9.3,3.5 \mathrm{~Hz}), 3.58(\mathrm{br} \mathrm{d}, 1 \mathrm{H}, J=$ $9.0 \mathrm{~Hz}$ ), $3.43(\mathrm{ddd}, 1 \mathrm{H} . J=12.8,12.8,3.0 \mathrm{~Hz}), 3.35-3.33(\mathrm{~m}, 1 \mathrm{H}), 2.10(\mathrm{br} \mathrm{d}, 1 \mathrm{H}, J=13.1 \mathrm{~Hz}), 1.44(\mathrm{ddd}, 1 \mathrm{H}, J=$ 13.3, 13.3, 4.9 Hz) ppm; ${ }^{13} \mathrm{C} \mathrm{NMR}\left(\mathrm{CDCl}_{3}, 125 \mathrm{MHz}\right) \delta 162.4,162.3,157.3,151.4,136.9,135.6,135.3,128.6$, 128.1, 128.0, 127.7, 127.6, 114.1, 114.0, 84.1, 80.8, 73.8, 68.7, 60.9, 55.5(2), 36.0, 29.8, 29.7 ppm; IR (thin film) $v$ 3339, 2944, 1624, 1581, 1521, 1499, 1386, 1258, 1133, 1023, $835 \mathrm{~cm}^{-1}$; HRMS (ES ${ }^{+}$) calcd for $\mathrm{C}_{30} \mathrm{H}_{36} \mathrm{~N}_{6} \mathrm{O}_{9} \mathrm{~S}_{2}$ 688.1985 found $711.1891\left(\mathrm{MNa}^{+}\right)$. Major isomer 53: ${ }^{1} \mathrm{H}$ NMR $\left(\mathrm{CD}_{3} \mathrm{CN}, 500 \mathrm{MHz}\right) \delta 7.87(\mathrm{br} \mathrm{s}, 1 \mathrm{H}), 7.78-7.76(\mathrm{~m}$, 2H), 7.76-7.73 (m, 2H), 7.43-7.33 (m, 5H), 7.01-6.98 (m, 2H), 6.97-6.94 (m, 2H), 6.41 (br s, 2H), 5.84 (br d, 1H, $J$ $=8.0 \mathrm{~Hz}), 5.07(\mathrm{br} \mathrm{s}, 1 \mathrm{H}), 4.45(\mathrm{~s}, 2 \mathrm{H}), 4.25(\mathrm{br} \mathrm{s}, 1 \mathrm{H}), 4.03-3.98(\mathrm{~m}, 1 \mathrm{H}), 3.95(\mathrm{dd}, 1 \mathrm{H}, J=3.4,3.4 \mathrm{~Hz}), 3.86(\mathrm{~s}$, $3 \mathrm{H}), 3.85$ (s, 3H), $3.64(\mathrm{ddd}, 1 \mathrm{H}, J=10.7,7.7,2.9 \mathrm{~Hz}), 3.61-3.51(\mathrm{~m}, 2 \mathrm{H}), 3.30$ (dd, $1 \mathrm{H}, J=9.8,7.9 \mathrm{~Hz}), 2.26-2.19$ $(\mathrm{m}, 1 \mathrm{H}), 1.86(\mathrm{dd}, 1 \mathrm{H}, J=12.9,6.5 \mathrm{~Hz}) \mathrm{ppm}$; IR (thin film) v 3332, 1626, 1576, 1536, 1402, 1258, 1130, 1081, 833 $\mathrm{cm}^{-1}$; HRMS $\left(\mathrm{ES}^{+}\right)$calcd for $\mathrm{C}_{30} \mathrm{H}_{36} \mathrm{~N}_{6} \mathrm{O}_{9} \mathrm{~S}_{2} 688.1985$ found $711.1860\left(\mathrm{MNa}^{+}\right)$.

Boron tris(trifluoroacetate): ${ }^{4}$ Neat $\mathrm{CF}_{3} \mathrm{CO}_{2} \mathrm{H}(620 \mu \mathrm{L}, 8.04 \mathrm{mmol}, 3.1$ equiv) was added dropwise to a Schlenk flask containing a $1.0 \mathrm{M}$ solution of $\mathrm{BBr}_{3}(2.60 \mathrm{~mL}, 2.60 \mathrm{mmol})$ in $\mathrm{CH}_{2} \mathrm{Cl}_{2}$ cooled to $0{ }^{\circ} \mathrm{C}$. The light brown solution was stirred for $40 \mathrm{~min}$ and was then concentrated in vacuo $(\sim 0.1 \mathrm{~mm} \mathrm{Hg})$ to a light brown powder. This material was dissolved in $5.2 \mathrm{~mL}$ of $\mathrm{CF}_{3} \mathrm{CO}_{2} \mathrm{H}$ and used in the subsequent transformation. The reagent appears to be stable to prolonged storage at $23^{\circ} \mathrm{C}$.

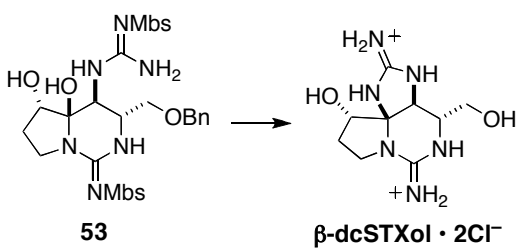

A $0.5 \mathrm{M} \mathrm{CF}_{3} \mathrm{CO}_{2} \mathrm{H}$ solution of $\mathrm{B}\left(\mathrm{O}_{2} \mathrm{CCF}_{3}\right)_{3}\left(560 \mu \mathrm{L}, 0.28 \mathrm{mmol}, 30\right.$ equiv) was added dropwise to a $0{ }^{\circ} \mathrm{C}$ solution of $53(6.0 \mathrm{mg}, 9.4 \mu \mathrm{mol})$ in $200 \mu \mathrm{L}$ of $\mathrm{CF}_{3} \mathrm{CO}_{2} \mathrm{H}$. The resulting light brown mixture was allowed to warm slowly to $23{ }^{\circ} \mathrm{C}$ over $6 \mathrm{~h}$. After stirring for $10.5 \mathrm{~h}$ the reaction was cooled in a cold-water bath and quenched by the dropwise addition of $1 \mathrm{~mL}$ of $\mathrm{MeOH}$. The solution was concentrated under reduced pressure then twice was re-dissolved in 1 $\mathrm{mL}$ of $\mathrm{MeOH}$ and concentrated. Purification of the light brown residue was performed by ion-exchange chromatography (Dowex $1 \times 8-200,{ }^{-} \mathrm{OH}$ form, $\mathrm{H}_{2} \mathrm{O}$ eluent). The fractions containing product were combined and acidified to $\mathrm{pH} \sim 2$ using $20 \mu \mathrm{L}$ of $1 \mathrm{M}$ aqueous $\mathrm{HCl}$. Lyophylization of this solution gave $\beta$-decarbamoylsaxitoxinol as a white solid $(1.8 \mathrm{mg}, 85 \%):[\alpha]_{\mathrm{D}}+116.2^{\circ}(\mathrm{c}=0.25, \mathrm{MeOH}) ;{ }^{1} \mathrm{H} \mathrm{NMR}\left(\mathrm{D}_{2} \mathrm{O}, 500 \mathrm{MHz}\right) \delta 4.67(\mathrm{~d}, 1 \mathrm{H}, J=1.5$ $\mathrm{Hz}), 4.25(\mathrm{~d}, 1 \mathrm{H}, J=4.3 \mathrm{~Hz}), 3.71(\mathrm{ddd}, 1 \mathrm{H}, J=10.2,10.2,2.2 \mathrm{~Hz}), 3.65-3.54(\mathrm{~m}, 4 \mathrm{H}), 2.38$ (dddd, $1 \mathrm{H}, J=14.7$, 9.8, 9.8, $4.3 \mathrm{~Hz}$ ), 2.17 (ddd, $1 \mathrm{H}, J=14.8,8.3,2.1 \mathrm{~Hz}) \mathrm{ppm} ;{ }^{13} \mathrm{C}$ NMR $\left(\mathrm{D}_{2} \mathrm{O}, 500 \mathrm{MHz}\right) \delta 157.1,155.4,82.9,74.2$, 60.9, 57.1, 55.0, 43.4, $28.3 \mathrm{ppm}$; HRMS $\left(\mathrm{ES}^{+}\right)$calcd for $\mathrm{C}_{9} \mathrm{H}_{16} \mathrm{~N}_{6} \mathrm{O}_{2} 240.1335$ found $241.1417\left(\mathrm{MH}^{+}\right)$.

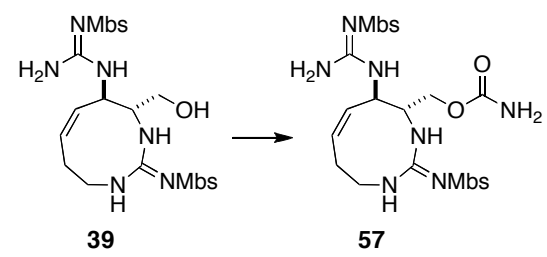

Cyclic guanidine $39(87 \mathrm{mg}, 0.163 \mathrm{mmol})$ was dissolved in $1.5 \mathrm{~mL}$ of an $8: 1 \mathrm{THF} / \mathrm{MeCN}$ mixture, and the reaction vessel was cooled to $-78^{\circ} \mathrm{C}$. A $0.84 \mathrm{mM}$ THF solution of trichloroacetyl isocyanate $(440 \mu \mathrm{L}, 0.369 \mathrm{mmol}, 2.3$ equiv) was added dropwise. The mixture was stirred for $1 \mathrm{~h}$ at $-78^{\circ} \mathrm{C}$ after which time the reaction was quenched at this temperature by the slow addition of $1 \mathrm{~mL}$ of $\mathrm{MeOH}$. The contents were warmed to $23{ }^{\circ} \mathrm{C}$ and solid $\mathrm{K}_{2} \mathrm{CO}_{3}(15$ $\mathrm{mg}, 0.11 \mathrm{mmol}, 0.67$ equiv) was added in a single portion. After stirring for $12 \mathrm{~h}$, the mixture was concentrated under reduced pressure to a solid mass. Purification of this material by chromatography on silica gel (gradient 
elution: 92:8 $\left.\rightarrow 90: 10 \mathrm{CH}_{2} \mathrm{Cl}_{2} / \mathrm{MeOH}\right)$ furnished carbamate 57 as a white solid $(81 \mathrm{mg}, 82 \%)$ : TLC $\mathrm{R}_{f}=0.29(10: 1$ $\left.\mathrm{CH}_{2} \mathrm{Cl}_{2} / \mathrm{MeOH}\right) ;[\alpha]_{\mathrm{D}}+164.3^{\circ}\left(\mathrm{c}=2.20\right.$, DMSO); ${ }^{1} \mathrm{H}$ NMR $\left(\mathrm{d}_{6}-\mathrm{DMSO}, 500 \mathrm{MHz}, 80{ }^{\circ} \mathrm{C}\right) \delta$ 7.74-7.64 (m, 4H) 7.03$6.95(\mathrm{~m}, 5 \mathrm{H}), 6.56$ (br s, 2H), 6.34 (br s, 2H), 4.66-4.60 (br m, 1H), 4.57-4.53 (m, 2H), $4.04(\mathrm{dd}, 1 \mathrm{H}, J=11.5,3.3$ $\mathrm{Hz}), 3.98(\mathrm{dd}, 1 \mathrm{H}, J=11.4,7.8 \mathrm{~Hz}), 3.84$ (s, 3H), 3.82 (s, 3H), 3.81-3.79 (m, 1H), 3.42-3.33 (br m, 2H), 3.10-3.02 (m, 1H), 2.76 (br s, 1H), 2.04 (br s, 1H) ppm; ${ }^{13} \mathrm{C}$ NMR $\left(\mathrm{d}_{6}\right.$-DMSO, $\left.125 \mathrm{MHz}, 80{ }^{\circ} \mathrm{C}\right) \delta 161.5,161.3,159.1,156.6$, $156.0,136.1,134.9,132.1,128.9,127.7,127.6,113.7,113.3,62.7,56.6,55.6,55.5,49.5,40.0$ (signal obscured by DMSO), 24.7 ppm; IR (thin film) v 3436, 3347, 1734, 1597, 1529, 1258, 1133, 1082, $815 \mathrm{~cm}^{-1}$; HRMS (ES HRalcd $^{+}$ for $\mathrm{C}_{24} \mathrm{H}_{31} \mathrm{~N}_{7} \mathrm{O}_{8} \mathrm{~S}_{2} 609.1676$ found $632.1580\left(\mathrm{MNa}^{+}\right)$.

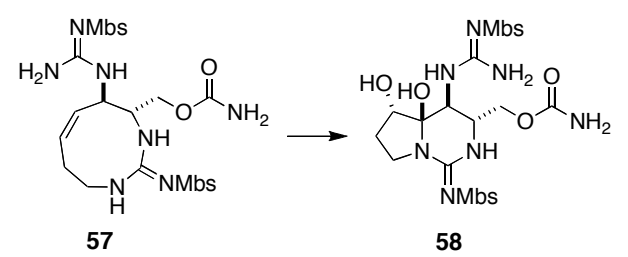

Oxone (234 mg, $0.345 \mathrm{mmol}, 7.0$ equiv) was added in a single portion to a mixture of $\mathrm{OsCl}_{3}$ ( $36 \mathrm{mM} \mathrm{M}$ solution in $\mathrm{H}_{2} \mathrm{O}, 136 \mu \mathrm{L}, 65 \mu \mathrm{mol}, 0.10$ equiv) and $\mathrm{Na}_{2} \mathrm{CO}_{3}(52 \mathrm{mg}, 0.49$ mmol, 10.0 equiv) in $2.2 \mathrm{~mL}$ of $11: 11: 2$ EtOAc/MeCN/ $\mathrm{H}_{2} \mathrm{O}$. Mild gas evolution was observed and the resulting yellow mixture was stirred for 2 min before carbamate 57 (30 mg, $49 \mu \mathrm{mol})$ was added. The contents were stirred vigorously for $48 \mathrm{~h}$. The reaction was then quenched by the addition of $2 \mathrm{~mL}$ of saturated aqueous $\mathrm{Na}_{2} \mathrm{~S}_{2} \mathrm{O}_{3}$ and the mixture was transferred to a separatory funnel containing $6 \mathrm{~mL}$ of $\mathrm{H}_{2} \mathrm{O}$ and $15 \mathrm{~mL}$ of EtOAc. The organic layer was collected and the aqueous phase was extracted with 1 x $15 \mathrm{~mL}$ of EtOAc. The combined organic extracts were washed with 1 x $5 \mathrm{~mL}$ of saturated aqueous $\mathrm{NaCl}$, dried over $\mathrm{MgSO}_{4}$, and concentrated under reduced pressure. The solid residue was purified by chromatography on silica gel $\left(92.5: 7.5 \mathrm{CH}_{2} \mathrm{Cl}_{2} / \mathrm{MeOH}\right)$ to give bicyclic guanidine $\mathbf{5 8}$ as a white solid (18 mg, $\left.57 \%\right)$. This product was obtained as a 12:1 mixture (as determined by HPLC) with the undesired 5/6 bicyclic isomer 59 (see text). The sample could be purified further by reverse phase HPLC (NovaPak $\mathrm{C}_{18}$, using 30:70 MeCN/ $\mathrm{H}_{2} \mathrm{O}+$ $1 \% \mathrm{CF}_{3} \mathrm{CO}_{2} \mathrm{H}$ as eluent with a flow rate of $4 \mathrm{~mL} / \mathrm{min} ; 254 \mathrm{~nm}$ UV detection). Under these conditions the desired product eluted with a retention time of $12.5 \mathrm{~min}:$ TLC $\mathrm{R}_{f}=0.21\left(10: 1 \mathrm{CH}_{2} \mathrm{Cl}_{2} / \mathrm{MeOH}\right) ;[\alpha]_{\mathrm{D}}-120.2^{\circ}(\mathrm{c}=2.00$, $\mathrm{MeOH}) ;{ }^{1} \mathrm{H}$ NMR $\left(\mathrm{CD}_{3} \mathrm{CN}, 500 \mathrm{MHz}\right) \delta$ 7.82-7.77 (m, 4H), $7.73(\mathrm{~s}, 1 \mathrm{H}), 7.06-7.01(\mathrm{~m}, 4 \mathrm{H}), 6.46(\mathrm{br} \mathrm{s}, 2 \mathrm{H}), 6.03$ (br d, $1 \mathrm{H}, J=6.1 \mathrm{~Hz}), 5.39$ (br s, $2 \mathrm{H}), 4.33$ (dd, $1 \mathrm{H}, J=11.8,2.5 \mathrm{~Hz}), 4.11-4.07$ (m, 1H), $3.97(\mathrm{~d}, 1 \mathrm{H}, J=3.8 \mathrm{~Hz})$, 3.89 (s, 3H), 3.88 (s, 3H), $3.76(\mathrm{dd}, 1 \mathrm{H}, J=11.8,5.7 \mathrm{~Hz}), 3.68(\mathrm{ddd}, 1 \mathrm{H}, J=11.1,5.6,2.3 \mathrm{~Hz}), 3.60-3.50$ (m, 2H),

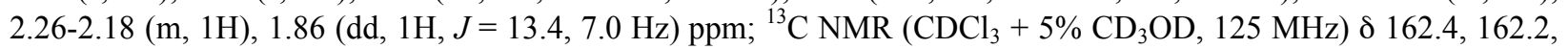
156.9, 156.5, 151.3, 134.4, 133.8, 128.0, 127.9, 114.0, 113.9, 89.4, 74.7, 63.8, 55.4 (2), 49.8, 47.2, 46.0, 29.6 ppm; IR (thin film) $v 3334,2924,1678,1579,1536,1499,1410,1260,1132,1081,834 \mathrm{~cm}^{-1}$; HRMS (ES ${ }^{+}$) calcd for $\mathrm{C}_{24} \mathrm{H}_{31} \mathrm{~N}_{7} \mathrm{O}_{10} \mathrm{~S}_{2} 641.1574$ found $664.1500\left(\mathrm{MNa}^{+}\right)$.

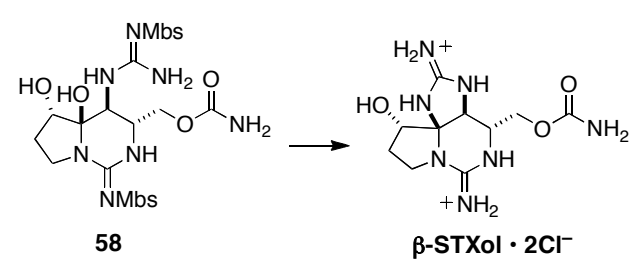

A $0.5 \mathrm{M}$ in $\mathrm{CF}_{3} \mathrm{CO}_{2} \mathrm{H}$ solution of $\mathrm{B}\left(\mathrm{O}_{2} \mathrm{CCF}_{3}\right)(1.90 \mathrm{~mL}, 30$ equiv) was added dropwise to a flask containing guanidine $58(20 \mathrm{mg}, 31 \mathrm{\mu mol})$ held in an ice-water bath. The light brown mixture was stirred vigorously as the contents warmed slowly over $5 \mathrm{~h}$ from 0 to $23{ }^{\circ} \mathrm{C}$. After stirring for $14 \mathrm{~h}$ at this temperature, the solution was cooled to $0^{\circ} \mathrm{C}$, quenched by the dropwise addition of $1 \mathrm{~mL}$ of $\mathrm{MeOH}$, and concentrated under reduced pressure. The solid residue was re-dissolved in $1 \mathrm{~mL}$ of $\mathrm{MeOH}$ and the solution was concentrated a second time. This process was repeated once. The isolated material was then dissolved in $0.5 \mathrm{~mL}$ of $\mathrm{H}_{2} \mathrm{O}$ and passed through a $2 \times 10 \mathrm{~cm}$ column of Dowex 1 x 8-200 ( ${ }^{-} \mathrm{OH}$ form). The fractions containing product, as determined by $\mathrm{pH}(\sim 7.5-8.0)$, were collected and acidified to a $\mathrm{pH}$ of $\sim 2$ with $20 \mu \mathrm{L}$ of $1 \mathrm{M}$ aqueous $\mathrm{HCl}$. The solution was lyophilized to give $\beta$ saxitoxinol $\cdot 2 \mathrm{Cl}^{-}$as a white powder $(9 \mathrm{mg}, 84 \%)$ : $[\alpha]_{\mathrm{D}}+126.5^{\circ}(\mathrm{c}=1.00, \mathrm{MeOH}) ;{ }^{1} \mathrm{H} \mathrm{NMR}\left(\mathrm{D}_{2} \mathrm{O}, 500 \mathrm{MHz}\right) \delta 4.77$ $(\mathrm{d}, 1 \mathrm{H}, J=1.1 \mathrm{~Hz}), 4.32(\mathrm{~d}, 1 \mathrm{H}, J=4.3 \mathrm{~Hz}), 4.25(\mathrm{dd}, 1 \mathrm{H}, J=11.5,9.2 \mathrm{~Hz}), 4.00(\mathrm{dd}, 1 \mathrm{H}, J=11.6,5.5 \mathrm{~Hz}), 3.82$ $(\mathrm{ddd}, 1 \mathrm{H}, J=9.3,5.4,1.1 \mathrm{~Hz}), 3.75(\mathrm{ddd}, 1 \mathrm{H}, J=10.2,10.2,2.0 \mathrm{~Hz}), 3.65(\mathrm{q}, 1 \mathrm{H}, J=9.5 \mathrm{~Hz}), 2.40(\mathrm{dddd}, 1 \mathrm{H}, J=$ 
14.7, 9.9, 9.8, 4.4 Hz), $2.22(\mathrm{ddd}, 1 \mathrm{H}, J=14.8,8.0,1.7 \mathrm{~Hz}) \mathrm{ppm} ;{ }^{13} \mathrm{C} \mathrm{NMR}\left(\mathrm{D}_{2} \mathrm{O}, 125 \mathrm{MHz}\right)^{8} \delta 158.6,157.3,155.4$, 83.0, 74.0, 62.7, 57.4, 52.5, 43.4, 28.4 ppm; HRMS $\left(\mathrm{ES}^{+}\right)$calcd for $\mathrm{C}_{10} \mathrm{H}_{17} \mathrm{~N}_{7} \mathrm{O}_{3} 283.1393$ found $284.1472\left(\mathrm{MH}^{+}\right)$.

The following experimental protocol is based on the procedure reported by Schantz et al. for the oxidation of $\alpha$-saxitoxinol: ${ }^{9}$

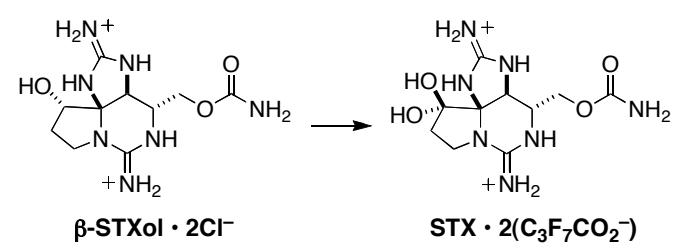

$\beta$-Saxitoxinol $\cdot 2 \mathrm{Cl}^{-}(4.5 \mathrm{mg}, 12 \mu \mathrm{mol})$ and powdered $3 \AA$ molecular sieves were combined in $500 \mu \mathrm{L}$ of DMSO and stirred for $30 \mathrm{~min}$. To this mixture were added dicyclohexylcarbodiimide ( $31 \mathrm{mg}, 0.15 \mathrm{mmol}, 12.0$ equiv) and pyridinium trifluoroacetate $(18 \mathrm{mg}, 94 \mu \mathrm{mol}, 7.5$ equiv). A dense precipitate formed immediately and the resulting turbid suspension was stirred vigorously for $17 \mathrm{~h}$. Lyophylization of the reaction mixture furnished a solid product that was suspended in $1 \mathrm{~mL}$ of $\mathrm{H}_{2} \mathrm{O}$ and filtered. An additional $1 \mathrm{~mL}$ of $\mathrm{H}_{2} \mathrm{O}$ was used to ensure quantitative transfer of the material. The combined filtrates were lypophylized and the obtained solid was purified by reversephase HPLC (Altima C18, $5 \mu \mathrm{m}, 10 \times 250 \mathrm{~mm}$ column, eluting with a gradient flow over 20 min of 12:88 MeCN/10 $\mathrm{mM}$ aqueous $\mathrm{C}_{3} \mathrm{~F}_{7} \mathrm{CO}_{2} \mathrm{H} \rightarrow$ 17:83 MeCN/10 mM aqueous $\mathrm{C}_{3} \mathrm{~F}_{7} \mathrm{CO}_{2} \mathrm{H}, 214 \mathrm{~nm}$ UV detection). At a flow rate of 6 $\mathrm{mL} / \mathrm{min}$, STX $\cdot 2\left(\mathrm{C}_{3} \mathrm{~F}_{7} \mathrm{CO}_{2}^{-}\right)$had a retention time of $13.0 \mathrm{~min}$ and was isolated as a white, hygroscopic solid (4.0 $\mathrm{mg}$, $60 \%):[\alpha]_{\mathrm{D}}+125 \pm 3^{\circ}\left(\mathrm{c}=0.13\left(\mathrm{Cl}^{-} \text {salt }\right)^{10}, \mathrm{H}_{2} \mathrm{O}\right)$; literature ${ }^{11}\left(\mathrm{Cl}^{-}\right.$salt $)[\alpha]_{\mathrm{D}}+130 \pm 5^{\circ} ;{ }^{1} \mathrm{H}$ NMR $\left(\mathrm{D}_{2} \mathrm{O}, 600 \mathrm{MHz}\right.$, HOD referenced at $4.80 \mathrm{ppm}) \delta 4.77(\mathrm{~d}, 1 \mathrm{H}, J=1.2 \mathrm{~Hz}), 4.32(\mathrm{dd}, 1 \mathrm{H}, J=11.7,9.3 \mathrm{~Hz}), 4.05(\mathrm{dd}, 1 \mathrm{H}, J=11.7,5.4$ $\mathrm{Hz}), 3.86(\mathrm{ddd}, 1 \mathrm{H}, J=9.3,5.2,1.1 \mathrm{~Hz}), 3.83(\mathrm{ddd}, 1 \mathrm{H}, J=10.0,9.8,2.0 \mathrm{~Hz}), 3.62-3.58(\mathrm{~m}, 1 \mathrm{H}), 2.45(\mathrm{ddd}, 1 \mathrm{H}, J=$ 14.1, 8.2, 2.0), 2.37 (ddd, $1 \mathrm{H}, J=14.0,10.1,10.0 \mathrm{~Hz}$ ) ppm; ${ }^{13} \mathrm{C}$ NMR $\left(\mathrm{D}_{2} \mathrm{O}, 600 \mathrm{MHz}\right.$, determined by $\mathrm{HMBC}$, appendix B) $\delta 159.7,158.2,156.5,99.5,83.1,64.3,57.6,53.7,43.8,33.5 \mathrm{ppm}$; HRMS $\left(\mathrm{ES}^{+}\right)$calcd for $\mathrm{C}_{10} \mathrm{H}_{15} \mathrm{~N}_{7} \mathrm{O}_{3}$ 281.1236 (ketone form) found $282.1327\left(\mathrm{MH}^{+}\right)$.

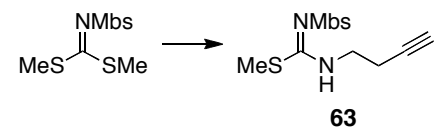

To a stirred suspension of [(4-methoxyphenyl)sulfonyl]carbonimidodithioic acid dimethyl ester ( $2.50 \mathrm{~g}, 8.61 \mathrm{mmol})$ in $20 \mathrm{~mL}$ of $\mathrm{MeOH}$ were added 3-butynylamine hydrochloride $\left(1.00 \mathrm{~g}, 9.47 \mathrm{mmol}, 1.1\right.$ equiv) and $\mathrm{Et}_{3} \mathrm{~N}(1.4 \mathrm{~mL}$, $10.3 \mathrm{mmol}, 1.2$ equiv). The reaction flask was fitted with a reflux condenser and the mixture was stirred at $50{ }^{\circ} \mathrm{C}$ for $30 \mathrm{~min}$. After cooling to $23{ }^{\circ} \mathrm{C}$, the solution was concentrated under reduced pressure to $\sim 1 / 3$ the original volume and transferred to a separatory funnel with $50 \mathrm{~mL}$ of EtOAc and $25 \mathrm{~mL}$ of $10 \%$ aqueous $\mathrm{NaHSO}_{4}$. The organic phase was collected and the aqueous layer was extracted with $3 \times 10 \mathrm{~mL}$ of EtOAc. The combined organic extracts were dried over $\mathrm{Na}_{2} \mathrm{SO}_{4}$, filtered, and concentrated under reduced pressure. The amorphous solid obtained was dissolved in $8.0 \mathrm{~mL}$ of boiling 5:3 EtOAc/heptane, then cooled slowly to $23{ }^{\circ} \mathrm{C}$. After allowing the mixture to stand for $2 \mathrm{~h}$ at $0{ }^{\circ} \mathrm{C}$, the product was collected by filtration through a Büchner funnel, rinsed with ice-cold heptane, and dried in vacuo to give $2.22 \mathrm{~g}$ of the desired isothiourea $63(83 \%)$. Following the same protocol, a second crop of material was collected from the mother liquor $(164 \mathrm{mg}, 6 \%)$ : TLC $\mathrm{R}_{f}=0.24\left(2: 1\right.$ hexanes/EtOAc); ${ }^{1} \mathrm{H}$ NMR $\left(\mathrm{CDCl}_{3}, 500 \mathrm{MHz}\right) \delta 8.42(\mathrm{br} \mathrm{s}, 1 \mathrm{H}), 7.87-7.81(\mathrm{~m}, 2 \mathrm{H}), 6.95-6.90(\mathrm{~m}, 2 \mathrm{H}), 3.83(\mathrm{~s}, 3 \mathrm{H}), 3.44(\mathrm{q}, 2 \mathrm{H}, J=6.4 \mathrm{~Hz})$, $2.48(\mathrm{td}, 2 \mathrm{H}, J=6.6,2.6 \mathrm{~Hz}), 2.35(\mathrm{~s}, 3 \mathrm{H}), 2.13-2.09$ (m, $1 \mathrm{H}) \mathrm{ppm} ;{ }^{13} \mathrm{C}$ NMR $\left(\mathrm{CDCl}_{3}, 125 \mathrm{MHz}\right) \delta 168.7,162.2$, 133.9, 128.0, 113.6, 79.5, 71.2, 55.3, 42.3, 19.0, 13.9 ppm; IR (thin film) v 3290, 1574, 1258, 1140, 1080, 1024, 834 $\mathrm{cm}^{-1}$; HRMS $\left(\mathrm{ES}^{+}\right)$calcd for $\mathrm{C}_{13} \mathrm{H}_{16} \mathrm{~N}_{2} \mathrm{O}_{3} \mathrm{~S}_{2} 312.0602$ found $335.0497\left(\mathrm{MNa}^{+}\right)$.

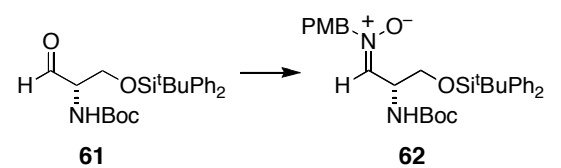

To a stirred solution of $(S)$-serinal $61(5.30 \mathrm{~g}, 12.4 \mathrm{mmol})$ in $125 \mathrm{~mL}$ of $\mathrm{CH}_{2} \mathrm{Cl}_{2}$ were added $N$-(4methoxybenzyl)hydroxylamine ${ }^{12}\left(1.90 \mathrm{~g}, 12.4 \mathrm{mmol}, 1.0\right.$ equiv) and $\mathrm{MgSO}_{4}$ (2.24 g, $18.6 \mathrm{mmol}, 1.5$ equiv). The 
resulting suspension was stirred for $5 \mathrm{~h}$ then poured through a sintered glass funnel. The flask and filter cake were washed with $3 \times 10 \mathrm{~mL}$ of $\mathrm{CH}_{2} \mathrm{Cl}_{2}$, and the combined filtrates were concentrated under reduced pressure to an oily residue. This material was dissolved in $60 \mathrm{~mL}$ of boiling 3:1 hexanes/EtOAc and cooled slowly to $23{ }^{\circ} \mathrm{C}$. After allowing the mixture to stand for $2 \mathrm{~h}$ at $0{ }^{\circ} \mathrm{C}$, the product was collected by filtration through a Büchner funnel, rinsed with ice-cold hexanes, and dried in vacuo to furnish nitrone $\mathbf{6 2}$ as a white solid (4.89 g, 70\%). Concentration of the mother liquor under reduced pressure and purification of the isolated residue by chromatography on silica gel (1:1 hexanes/EtOAc) afforded a second batch of $62(420 \mathrm{mg}, 6 \%)$. TLC $\mathrm{R}_{f}=0.20\left(1: 1\right.$ hexanes/EtOAc); ${ }^{1} \mathrm{H}$ NMR $\left(\mathrm{CDCl}_{3}, 400 \mathrm{MHz}\right) \delta$ 7.60-7.53 (m, 4H), 7.46-7.32 (m, 6H), 7.31-7.25 (m, 2H), 6.92-6.85 (m, 2H), $6.71(\mathrm{br} \mathrm{s}, 1 \mathrm{H})$, $5.77($ br s, $1 \mathrm{H}), 4.78(\mathrm{~s}, 2 \mathrm{H}), 4.76-4.68(\mathrm{~m}, 1 \mathrm{H}), 4.00-3.95(\mathrm{~m}, 1 \mathrm{H}), 3.95-3.86(\mathrm{~m}, 1 \mathrm{H}), 3.80(\mathrm{~s}, 3 \mathrm{H}), 1.40(\mathrm{~s}, 9 \mathrm{H})$, $1.02(\mathrm{~s}, 9 \mathrm{H}) \mathrm{ppm} ;{ }^{13} \mathrm{C}$ NMR $\left(\mathrm{CDCl}_{3}, 100 \mathrm{MHz}, 55^{\circ} \mathrm{C}\right) \delta 160.3,155.2,136.0,135.4,135.4,133.3,133.2,130.9$, $129.7,129.7,127.7,127.7,124.7,114.4,79.6,69.1,62.7,55.2,50.5,28.3,26.8,19.2 \mathrm{ppm}$; IR (thin film) v 3270 , $3072,2961,2933,2858,1710,1514,1252,1175,1113,823 \mathrm{~cm}^{-1}$; HRMS (ES ${ }^{+}$calcd for $\mathrm{C}_{32} \mathrm{H}_{42} \mathrm{~N}_{2} \mathrm{O}_{5} \mathrm{Si} 562.2863$ found $585.2764\left(\mathrm{MNa}^{+}\right)$.

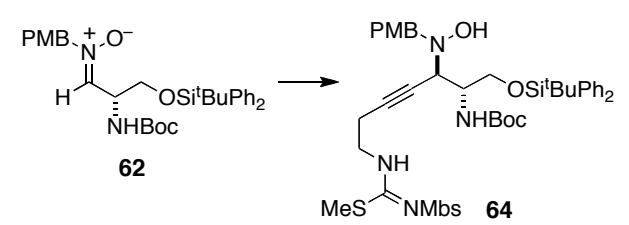

A 3-neck, $250 \mathrm{~mL}$ round bottom flask equipped with a rubber septum, internal thermometer, and a glass stopper was charged with isothiourea $63(2.73 \mathrm{~g}, 8.74 \mathrm{mmol}, 3.0$ equiv) and $15 \mathrm{~mL}$ of THF. The vessel was cooled in a $\mathrm{MeOH} /$ ice bath to $-15{ }^{\circ} \mathrm{C}$, and to the solution was added dropwise $9.5 \mathrm{~mL}$ of $1.9 \mathrm{M}{ }^{i} \mathrm{PrMgCl}(17.9 \mathrm{mmol}, 6.15$ equiv) in THF. The contents were stirred at $-15^{\circ} \mathrm{C}$ for $5 \mathrm{~min}$, then warmed to $0{ }^{\circ} \mathrm{C}$. After $30 \mathrm{~min}$, the mixture was cooled to $-78{ }^{\circ} \mathrm{C}$ and a solution of nitrone $62(1.64 \mathrm{~g}, 2.91 \mathrm{mmol})$ in $5.0 \mathrm{~mL}$ of THF was added dropwise via cannula. The internal temperature of the reaction did not rise above $-65{ }^{\circ} \mathrm{C}$ during the addition process. An additional $3.0 \mathrm{~mL}$ of THF was used to ensure quantitative transfer of the nitrone. The resulting pale yellow suspension was stirred for $1 \mathrm{~h}$ at $-78^{\circ} \mathrm{C}$, after which time the mixture was warmed to $-50{ }^{\circ} \mathrm{C}$. At this temperature, all solids had dissolved and stirring of the pale yellow solution was continued for $2 \mathrm{~h}$. The reaction was then diluted with $150 \mathrm{~mL}$ of $\mathrm{Et}_{2} \mathrm{O}$ and quenched with $75 \mathrm{~mL}$ of $2 / 3$ saturated aqueous $\mathrm{NH}_{4} \mathrm{Cl}$. The contents were transferred to a separatory funnel, the organic phase was collected, and the aqueous layer was extracted with $3 \times 25 \mathrm{~mL}^{\text {of }} \mathrm{Et}_{2} \mathrm{O}$. The combined organic extracts were dried over $\mathrm{MgSO}_{4}$, filtered, and concentrated under reduced pressure to an oily residue. Analysis of unpurified product by ${ }^{1} \mathrm{H}$ NMR showed a 4-5:1 diastereomeric ratio of products, as determined by integration of the tert-butyl signals. Purification by chromatography on silica gel (gradient elution: 2:2:1 $\mathrm{CH}_{2} \mathrm{Cl}_{2}$ /hexanes/EtOAc $\rightarrow$ 1:1 hexanes/EtOAc) afforded the desired anti-diamine $\mathbf{6 4}$ as a white foam (1.98 g, 78\%). A large portion of alkyne $\mathbf{6 3}$ was recovered as a white solid $(1.27 \mathrm{~g}, 70 \%)$ : TLC $\mathrm{R}_{f}=0.23(2: 2: 1$ $\mathrm{CH}_{2} \mathrm{Cl}_{2} /$ hexanes/EtOAc); ${ }^{1} \mathrm{H}\left(\mathrm{CDCl}_{3}, 500 \mathrm{MHz}, 50{ }^{\circ} \mathrm{C}\right) \delta 8.40(\mathrm{br} \mathrm{s}, 1 \mathrm{H}), 7.82(\mathrm{~d}, 2 \mathrm{H}, J=8.8 \mathrm{~Hz}), 7.67-7.59(\mathrm{~m}$, $4 \mathrm{H}), 7.44-7.33(\mathrm{~m}, 6 \mathrm{H}), 7.29(\mathrm{~d}, 2 \mathrm{H}, J=8.5 \mathrm{~Hz}), 6.91-6.86(\mathrm{~m}, 2 \mathrm{H}), 6.85-6.79(\mathrm{~m}, 2 \mathrm{H}), 6.06(\mathrm{br} \mathrm{s}, 1 \mathrm{H}), 5.17(\mathrm{br}$ s, $1 \mathrm{H}), 4.32-4.14(\mathrm{~m}, 2 \mathrm{H}), 3.92-3.83(\mathrm{~m}, 2 \mathrm{H}), 3.82(\mathrm{~s}, 3 \mathrm{H}), 3.78(\mathrm{~s}, 3 \mathrm{H}), 3.74(\mathrm{dd}, 1 \mathrm{H}, J=9.9,6.5 \mathrm{~Hz}), 3.50-3.28(\mathrm{~m}$, $2 \mathrm{H}), 2.59-2.47(\mathrm{~m}, 2 \mathrm{H}), 2.37(\mathrm{~s}, 3 \mathrm{H}), 1.42(\mathrm{~s}, 9 \mathrm{H}), 1.03(\mathrm{~s}, 9 \mathrm{H}) \mathrm{ppm} ;{ }^{13} \mathrm{C}\left(\mathrm{CDCl}_{3}, 100 \mathrm{MHz}, 50{ }^{\circ} \mathrm{C}\right) \delta 168.7(\mathrm{br})$, $162.4,158.8,156.9$ (br), 135.5, 135.5, 134.5, 133.2, 133.1, 130.2, 129.6, 129.6, 128.2, 127.6, 127.6, 113.7, 113.6, 83.7 (br), 79.4, 78.1 (br), 63.3, 61.0, 60.1, 55.3, 55.1, 53.2, 42.7, 28.2, 26.7, 19.7, 19.1, 13.9 ppm; IR (thin film) $v$ $3376,2932,2857,1697,1575,1512,1253,1139,1111,831 \mathrm{~cm}^{-1}$; HRMS $\left(\mathrm{ES}^{+}\right)$calcd for $\mathrm{C}_{45} \mathrm{H}_{58} \mathrm{~N}_{4} \mathrm{O}_{8} \mathrm{~S}_{2} \mathrm{Si} 874.3465$ found $897.3357\left(\mathrm{MNa}^{+}\right)$.

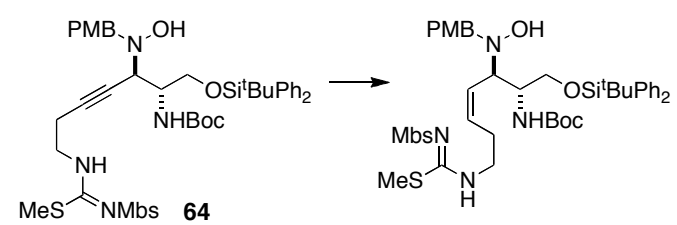

A thick-walled pressure tube was charged with diamine $64(1.88 \mathrm{~g}, 2.15 \mathrm{mmol})$ and $15 \mathrm{~mL}$ of a $2: 1 \mathrm{THF} / \mathrm{H}_{2} \mathrm{O}$ solution. To this mixture were added $p$-toluenesulfonyl hydrazide ( $800 \mathrm{mg}, 4.30 \mathrm{mmol}, 2.0$ equiv) and anhydrous sodium acetate ( $529 \mathrm{mg}, 6.44 \mathrm{mmol}, 3.0$ equiv). After sealing the tube with a threaded Teflon stopper, the reaction vessel was submerged in an oil bath preheated to $100^{\circ} \mathrm{C}$. The reaction mixture was stirred for $1 \mathrm{~h}$ then cooled to 23 
${ }^{\circ} \mathrm{C}$ prior to removing carefully the Teflon plug. A second portion of $p$-toluenesulfonyl hydrazide $(800 \mathrm{mg}, 4.30$ $\mathrm{mmol}, 2.0$ equiv) and anhydrous sodium acetate $(529 \mathrm{mg}, 6.44 \mathrm{mmol}, 3.0$ equiv) were added, the reaction vessel was sealed, and the solution was stirred at $100{ }^{\circ} \mathrm{C}$. Following a $1 \mathrm{~h}$ period, the contents were cooled to $23{ }^{\circ} \mathrm{C}$ and the Teflon stopper was carefully removed. A third portion of $p$-toluenesulfonyl hydrazide $(800 \mathrm{mg}, 4.30 \mathrm{mmol}, 2.0$ equiv) and anhydrous sodium acetate $(529 \mathrm{mg}, 6.44 \mathrm{mmol}, 3.0$ equiv) were added, the reaction vessel was sealed, and the solution was stirred at $100{ }^{\circ} \mathrm{C}$ for $1 \mathrm{~h}$. Upon cooling to $23{ }^{\circ} \mathrm{C}$, the flask was unstoppered and the contents were transferred to a separatory funnel with $50 \mathrm{~mL}$ of EtOAc and $20 \mathrm{~mL}$ of saturated aqueous $\mathrm{NaHCO}_{3}$. The organic phase was collected and washed a second time with $20 \mathrm{~mL}$ of saturated aqueous $\mathrm{NaHCO}_{3}$. The combined aqueous layers were extracted with $3 \times 10 \mathrm{~mL}$ of EtOAc. The collected organic fractions were dried over $\mathrm{Na}_{2} \mathrm{SO}_{4}$, filtered, and concentrated under reduced pressure to an oily residue. Purification by chromatography on silica gel $\left(5: 2\right.$ toluene/ $\left.\mathrm{Et}_{2} \mathrm{O}\right)$ afforded the desired cis-alkene as a white foam $(1.47 \mathrm{~g}, 78 \%)$ : TLC $\mathrm{R}_{f}=0.40(2: 1$ toluene/Et $\left.{ }_{2} \mathrm{O}\right) ;{ }^{1} \mathrm{H}$ NMR $\left(\mathrm{CDCl}_{3}, 400 \mathrm{MHz}, 50{ }^{\circ} \mathrm{C}\right) \delta 8.17$ (br s, $\left.1 \mathrm{H}\right), 7.86-7.78(\mathrm{~m}, 2 \mathrm{H}), 7.70-7.60(\mathrm{~m}, 4 \mathrm{H}), 7.46-$ $7.34(\mathrm{~m}, 6 \mathrm{H}), 7.24-7.17(\mathrm{~m}, 2 \mathrm{H}), 6.95-6.88(\mathrm{~m}, 2 \mathrm{H}), 6.85-6.78(\mathrm{~m}, 2 \mathrm{H}), 5.95(\mathrm{br} \mathrm{s}, 1 \mathrm{H}), 5.76-5.57(\mathrm{~m}, 2 \mathrm{H}), 4.75(\mathrm{~d}$, $1 \mathrm{H}, J=9.5 \mathrm{~Hz}), 4.30-4.04(\mathrm{~m}, 1 \mathrm{H}), 3.94(\mathrm{~d}, 1 \mathrm{H}, J=14.0 \mathrm{~Hz}), 3.83(\mathrm{~s}, 3 \mathrm{H}), 3.78(\mathrm{~s}, 3 \mathrm{H}), 3.73(\mathrm{dd}, 1 \mathrm{H}, J=10.2,5.2$ $\mathrm{Hz}), 3.66(\mathrm{dd}, 1 \mathrm{H}, J=9.5,5.2 \mathrm{~Hz}), 3.58(\mathrm{~d}, 1 \mathrm{H}, J=13.6 \mathrm{~Hz}), 3.33-3.20(\mathrm{~m}, 2 \mathrm{H}), 2.43-2.19(\mathrm{~m}, 2 \mathrm{H}), 2.33(\mathrm{~s}, 3 \mathrm{H})$, $1.44(\mathrm{~s}, 9 \mathrm{H}), 1.07$ (s, 9H) ppm; ${ }^{13} \mathrm{C} \mathrm{NMR}\left(\mathrm{CDCl}_{3}, 100 \mathrm{MHz}, 50{ }^{\circ} \mathrm{C}\right) \delta 168.7,162.4,158.6,156.2,135.5,135.5$, 135.4, 134.7, 133.2, 133.1, 130.5, 129.8, 129.7, 129.6, 128.1, 127.7, 127.7, 113.8, 113.5, 79.3, 64.3, 63.1, 60.2, 55.3, 55.1, 53.6, 43.6, 28.3, 28.1, 26.8, 19.1, 13.9 ppm; IR (thin film) v 3369, 2931, 2856, 1700, 1576, 1512, 1499, 1254 , $1173,1138,1112,1080,859,831 \mathrm{~cm}^{-1}$; HRMS $\left(\mathrm{ES}^{+}\right)$calcd for $\mathrm{C}_{45} \mathrm{H}_{60} \mathrm{~N}_{4} \mathrm{O}_{8} \mathrm{~S}_{2} \mathrm{Si} 876.3622$ found $899.3510\left(\mathrm{MNa}^{+}\right)$.

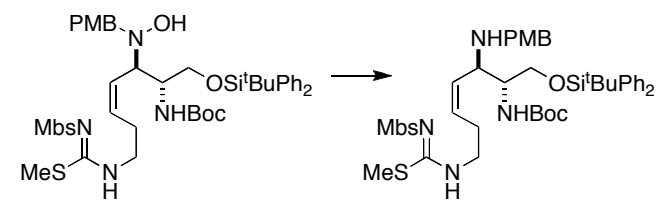

To a slurry of zinc dust $\left(510 \mathrm{mg}, 7.81 \mathrm{mmol}, 5.0\right.$ equiv) in $3.0 \mathrm{~mL}$ of $\mathrm{AcOH}$ was added anhydrous $\mathrm{Cu}(\mathrm{OAc})_{2} \quad(28$ $\mathrm{mg}, 156 \mu \mathrm{mol}, 0.10$ equiv). The gray suspension was stirred for $15 \mathrm{~min}$ following which time a solution of cisalkene $(1.37 \mathrm{~g}, 1.56 \mathrm{mmol})$ in $4.0 \mathrm{~mL}$ of $\mathrm{AcOH}$ was added via cannula. Transfer of this material was made quantitative with an additional $1.0 \mathrm{~mL}$ of $\mathrm{AcOH}$ and $2.0 \mathrm{~mL}$ of $\mathrm{H}_{2} \mathrm{O}$. The reaction vessel was sealed with a glass stopper, submerged in an oil bath, and the contents were stirred at $70{ }^{\circ} \mathrm{C}$ for $1 \mathrm{~h}$. After cooling the reaction to $23{ }^{\circ} \mathrm{C}$, $500 \mathrm{mg}$ of solid $\mathrm{Na}_{2}$ EDTA was added in a single portion. The mixture was stirred vigorously for $5 \mathrm{~min}$, then the solution was made basic $(\mathrm{pH} \sim 10)$ by the dropwise addition of $40 \mathrm{~mL}$ of $10 \%$ aqueous $\mathrm{NaOH}$. Subsequent addition of $100 \mathrm{~mL}$ of EtOAc gave a biphasic solution, which was stirred vigorously for $1 \mathrm{~min}$ and then filtered through a small pad of Celite. The flask and the filter cake were rinsed with $100 \mathrm{~mL}$ of EtOAc and $50 \mathrm{~mL}$ of $\mathrm{H}_{2} \mathrm{O}$. After transferring the combined filtrates to a separatory funnel, the organic phase was collected and the aqueous phase was extracted with $3 \times 20 \mathrm{~mL}$ of EtOAc. The combined organic fractions were washed successively with $1 \times 30 \mathrm{~mL}$ of saturated aqueous EDTA and $1 \times 30 \mathrm{~mL}$ of saturated aqueous $\mathrm{NaCl}$, dried over $\mathrm{Na}_{2} \mathrm{SO}_{4}$, filtered and concentrated under reduced pressure. Purification of the foamy residue by chromatography on silica gel (gradient elution: $1: 1 \rightarrow 2: 3$ hexanes/EtOAc) afforded the desired $2^{\circ}$ amine as a white foam $(1.08 \mathrm{~g}, 81 \%)$ : TLC $\mathrm{R}_{f}=0.23(1: 1$ hexanes/EtOAc); ${ }^{1} \mathrm{H}$ NMR $\left(\mathrm{CDCl}_{3}, 400 \mathrm{MHz}\right) \delta 8.30-8.20(\mathrm{~m}, 1 \mathrm{H}), 7.87-7.79(\mathrm{~m}, 2 \mathrm{H})$, 7.68-7.57 (m, 4H), 7.46-7.32 $(\mathrm{m}, 6 \mathrm{H}), 7.25-7.17(\mathrm{~m}, 2 \mathrm{H}), 6.95-6.88(\mathrm{~m}, 2 \mathrm{H}), 6.86-6.78(\mathrm{~m}, 2 \mathrm{H}), 5.61-5.50(\mathrm{~m}, 1 \mathrm{H}), 5.45(\mathrm{dd}, 1 \mathrm{H}, J=10.1 \mathrm{~Hz})$, 5.36-5.20 (m, 1H), $3.91(\mathrm{~d}, 1 \mathrm{H}, J=10.2 \mathrm{~Hz}), 3.83(\mathrm{~s}, 3 \mathrm{H}), 3.78(\mathrm{~s}, 3 \mathrm{H}), 3.76(\mathrm{~d}, 1 \mathrm{H}, J=13.6 \mathrm{~Hz}), 3.71(\mathrm{~d}, 1 \mathrm{H}, J=$ $10.8 \mathrm{~Hz}), 3.67-3.56(\mathrm{~m}, 2 \mathrm{H}), 3.52(\mathrm{~d}, 1 \mathrm{H}, J=12.8 \mathrm{~Hz}), 3.33-3.16(\mathrm{~m}, 2 \mathrm{H}), 2.41-2.21(\mathrm{~m} .2 \mathrm{H}), 2.32(\mathrm{~s}, 3 \mathrm{H}), 1.56(\mathrm{br}$ $\mathrm{s}, 1 \mathrm{H}), 1.43(\mathrm{~s}, 9 \mathrm{H}), 1.02(\mathrm{~s}, 9 \mathrm{H}) \mathrm{ppm} ;{ }^{13} \mathrm{C} \mathrm{NMR}\left(\mathrm{CDCl}_{3}, 100 \mathrm{MHz}\right) \delta$ 168.7, 162.2, 158.3, 155.4, 135.3, 135.3, 134.3, 133.4, 132.8, 132.8, 132.1, 129.6, 129.6, 129.1, 128.0, 127.8, 127.6, 127.6, 113.6, 113.5, 78.9, 63.5, 55.3, $55.1,55.0,54.3,50.3,43.7,28.3,27.4,26.7,19.0,13.9 \mathrm{ppm}$; IR (thin film) v 3294, 2931, 2856, 1708, 1575, 1512, $1498,1255,1173,1138,1111,1080,860,831 \mathrm{~cm}^{-1}$; HRMS (ES ${ }^{+}$) calcd for $\mathrm{C}_{45} \mathrm{H}_{60} \mathrm{~N}_{4} \mathrm{O}_{7} \mathrm{~S}_{2} \mathrm{Si} 860.3673$ found $861.3763\left(\mathrm{MH}^{+}\right)$.

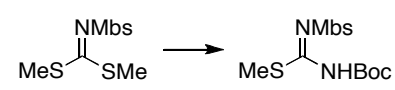

To a stirred suspension of $N$-[bis(methylthio)methylene]-4-methoxybenzenesulfonamide (2.00 g, $6.86 \mathrm{mmol})$ in 14 $\mathrm{mL}$ of $\mathrm{MeOH}$ was added $5.2 \mathrm{~mL}$ of $2.0 \mathrm{M}$ methanolic $\mathrm{NH}_{3}$ (10.3 mmol, 1.50 equiv). The reaction vessel was sealed with a glass stopper, submerged in an oil bath, and the mixture was stirred for $30 \mathrm{~min}$ at $50{ }^{\circ} \mathrm{C}$. Following this time, 
the reaction was cooled to $23{ }^{\circ} \mathrm{C}$ and all volatiles were removed under reduced pressure. The isolated, off-white amorphous solid was suspended in $20 \mathrm{~mL}$ of THF and the slurry was warmed gently with a heat gun to effect dissolution. To the resulting homogeneous medium was then added via cannula a solution of $\mathrm{Boc}_{2} \mathrm{O}(1.57 \mathrm{~g}, 7.21$ mmol, 1.05 equiv) in $10 \mathrm{~mL}$ of THF. An additional $5.0 \mathrm{~mL}$ of THF was used to ensure quantitative transfer of $\mathrm{Boc}_{2} \mathrm{O}$. The flask was quickly unstoppered and a single portion of DMAP (42 mg, $342 \mu \mathrm{mol}, 0.05$ equiv) was added. After stirring the reaction mixture for $12 \mathrm{~h}$, the solution was concentrated under reduced pressure to a solid residue. Purification of this material by chromatography on silica gel (3:1 hexanes/EtOAc) afforded the desired isothiourea as a white powder (2.35 g, 95\%): TLC $\mathrm{R}_{f}=0.29$ (3:1 hexanes/EtOAc); ${ }^{1} \mathrm{H}$ NMR $\left(\mathrm{CDCl}_{3}, 400 \mathrm{MHz}\right) \delta$ $10.3($ br s, $1 \mathrm{H}), 7.90-7.83(\mathrm{~m}, 2 \mathrm{H}), 7.01-6.94(\mathrm{~m}, 2 \mathrm{H}), 3.87(\mathrm{~s}, 3 \mathrm{H}), 2.27(\mathrm{~s}, 3 \mathrm{H}), 1.51(\mathrm{~s}, 9 \mathrm{H}) \mathrm{ppm} ;{ }^{13} \mathrm{C}$ NMR $\left(\mathrm{CDCl}_{3}, 100 \mathrm{MHz}\right) \delta 167.0,162.9,149.9,132.7,128.5,114.0,84.1,55.5,27.8,14.7 \mathrm{ppm}$; IR (thin film) v 3247, $2980,1752,1563,1295,1260,1232,1153,1085,847 \mathrm{~cm}^{-1}$; HRMS $\left(\right.$ ES $\left.^{+}\right)$calcd for $\mathrm{C}_{14} \mathrm{H}_{20} \mathrm{~N}_{2} \mathrm{O}_{5} \mathrm{~S}_{2} 360.0814$ found $383.0715\left(\mathrm{MNa}^{+}\right)$.

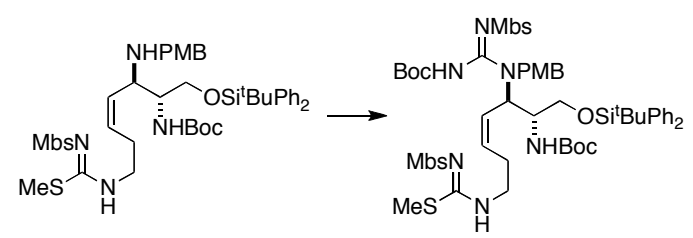

A solution of $N$-Boc- $N$ '-Mbs isothiourea ( $500 \mathrm{mg}, 1.39 \mathrm{mmol}, 4.0$ equiv) in $5.5 \mathrm{~mL}$ of $\mathrm{CH}_{2} \mathrm{Cl}_{2}$ was added to a rubber septum-stoppered, flame-dried $16 \times 125 \mathrm{~mm}$ test tube containing anhydrous $\mathrm{HgCl}_{2}$ (189 mg, $0.69 \mathrm{mmol}, 2.0$ equiv). The clear, colorless mixture was stirred rapidly while neat $\mathrm{Et}_{3} \mathrm{~N}(0.21 \mathrm{~mL}, 1.53 \mathrm{mmol}, 4.4$ equiv) was added dropwise. A white precipitate formed immediately; the resulting slurry was stirred vigorously for $15 \mathrm{~min}$. After allowing the precipitate to settle, the test tube was placed in a centrifuge and spun at $1550 \mathrm{rpm}$ for $5 \mathrm{~min}$. With the aid of a syringe, $5.0 \mathrm{~mL}$ of the colorless supernatant was withdrawn and added dropwise to a solution of PMB-amine (299 mg, $347 \mu \mathrm{mol}$ ) in $1.5 \mathrm{~mL} \mathrm{CH} \mathrm{Cl}_{2}$. The reaction vessel was equipped with a reflux condenser and the contents were stirred for $5 \mathrm{~min}$ at $40{ }^{\circ} \mathrm{C}$. After cooling the suspension to $23^{\circ} \mathrm{C}$, the mixture was filtered through a small pad of Celite, rinsing the flask and filter cake with $50 \mathrm{~mL}$ of $\mathrm{CH}_{2} \mathrm{Cl}_{2}$. The combined filtrates was transferred to a separatory funnel and the organic solution was washed with $10 \%$ aqueous $\mathrm{NaHSO}_{4}$. The organic layer was collected and the aqueous phase was extracted with $3 \times 10 \mathrm{~mL}$ of $\mathrm{CH}_{2} \mathrm{Cl}_{2}$. The combined organic extracts were dried over $\mathrm{Na}_{2} \mathrm{SO}_{4}$, filtered, and concentrated under reduced pressure to an oily residue. Purification by chromatography on silica gel (gradient elution: 3:3:1 $\rightarrow 2: 2: 1 \mathrm{CH}_{2} \mathrm{Cl}_{2}$ /hexanes/EtOAc) afforded the desired $N$-Boc guanidine as a white foam (300 mg, 74\%): TLC $\mathrm{R}_{f}=0.36\left(2: 2: 1 \mathrm{CH}_{2} \mathrm{Cl}_{2} /\right.$ hexanes/EtOAc); ${ }^{1} \mathrm{H}$ NMR $\left(\mathrm{CD}_{3} \mathrm{CN}, 400 \mathrm{MHz}, 70{ }^{\circ} \mathrm{C}\right) \delta 8.16$ (br s, 1H), 7.86-7.79 (m, 2H), 7.71-7.65 (m, 4H), 7.65-7.53 (m, 2H), 7.49-7.34 (m, 6H), 7.06-6.95 (m, 4H), 6.88$6.82(\mathrm{~m}, 2 \mathrm{H}), 6.82-6.76(\mathrm{~m}, 2 \mathrm{H}), 5.70(\mathrm{dd}, 1 \mathrm{H}, J=10.4,10.4 \mathrm{~Hz}), 5.51(\mathrm{ddd}, 1 \mathrm{H}, J=10.2,7.3,7.3 \mathrm{~Hz}), 5.24-4.98$ (m, $1 \mathrm{H}), 5.00(\mathrm{dd}, 1 \mathrm{H}, J=8.8 \mathrm{~Hz}), 4.42(\mathrm{~s}, 2 \mathrm{H}), 4.15-4.02(\mathrm{~m}, 1 \mathrm{H}), 3.86(\mathrm{dd}, 1 \mathrm{H}, J=10.8,3.8 \mathrm{~Hz}), 3.83(\mathrm{~s}, 3 \mathrm{H})$, $3.76(\mathrm{~s}, 3 \mathrm{H}), 3.75(\mathrm{~s}, 3 \mathrm{H}), 3.67(\mathrm{dd}, 1 \mathrm{H}, J=10.7,7.6 \mathrm{~Hz}), 3.40-3.13(\mathrm{~m}, 2 \mathrm{H}), 2.42-2.28(\mathrm{~m}, 2 \mathrm{H}), 2.33(\mathrm{~s}, 3 \mathrm{H}), 1.40$ (s, 9H), 1.39 (s, 9H), 1.06 (s, 9H) ppm; ${ }^{13} \mathrm{C}$ NMR $\left(\mathrm{CD}_{3} \mathrm{CN}, 100 \mathrm{MHz}, 70{ }^{\circ} \mathrm{C}\right) \delta 163.9,163.8,160.6,156.7,153.6$, $150.8,136.8,136.8,136.0,135.1,134.9,132.5$ (br), 131.0, 131.0, 129.7, 129.4, 129.3, 129.2, 129.0, 129.0, 127.7 (br), 115.4, 115.3, 115.3, 84.2, 80.0, 64.6, 58.8, 56.7, 56.6, 56.3, 55.5 (br), 51.2 (br), 44.7, 29.0, 28.6, 27.8, 20.2, $14.8 \mathrm{ppm}$; IR (thin film) v 3294, 2932, 1749, 1711, 1574, 1257, 1140, 1082, 1028, 869, 831, $805 \mathrm{~cm}^{=1}$; HRMS (ES ${ }^{+}$) calcd for $\mathrm{C}_{58} \mathrm{H}_{76} \mathrm{~N}_{6} \mathrm{O}_{12} \mathrm{~S}_{3} \mathrm{Si} 1172.4453$ found $1195.4349\left(\mathrm{MNa}^{+}\right)$.

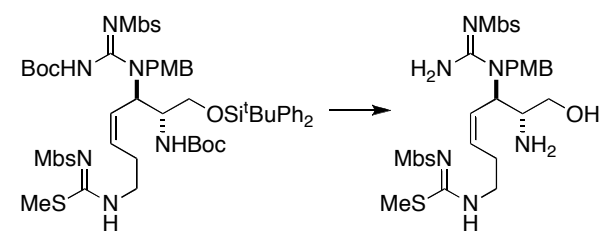

$N$-Boc guanidine $(149 \mathrm{mg}, 136 \mu \mathrm{mol})$ was dissolved in $3.0 \mathrm{~mL}$ of $1.0 \mathrm{M}$ methanolic $\mathrm{HCl}$, the reaction vessel was sealed with a glass stopper, and the solution was stirred at $40{ }^{\circ} \mathrm{C}$ for $12 \mathrm{~h}$. Following this time, the reaction was cooled to $23^{\circ} \mathrm{C}$ and all volatiles were removed under reduced pressure. The isolated off-white film was suspended in $3.0 \mathrm{~mL}$ of $\mathrm{CH}_{2} \mathrm{Cl}_{2}$ and to this mixture was added neat $\mathrm{Et}_{3} \mathrm{~N}(0.19 \mathrm{~mL}, 1.36 \mathrm{mmol}, 10$ equiv). After stirring for 15 min, the solution was concentrated under reduced pressure. Purification of the amorphous solid by chromatography 
on silica gel $\left(9: 1 \mathrm{CH}_{2} \mathrm{Cl}_{2} / \mathrm{MeOH}\right)$ afforded the amino alcohol as an opaque oil (52 mg, 52\%): TLC $\mathrm{R}_{f}=0.22$ (93:7 $\left.\mathrm{CH}_{2} \mathrm{Cl}_{2} / \mathrm{MeOH}\right) ;{ }^{1} \mathrm{H}$ NMR $\left(\mathrm{CD}_{3} \mathrm{CN}, 500 \mathrm{MHz}, 70{ }^{\circ} \mathrm{C}\right) \delta$ 7.83-7.88 (m, $\left.2 \mathrm{H}\right), 7.77-7.72(\mathrm{~m}, 2 \mathrm{H}), 7.60-7.20(\mathrm{br} \mathrm{s}, 2 \mathrm{H})$, 7.08-7.03 (m, 2H), 7.03-6.99 (m, 2H), 6.99-6.95 (m, 2H), 6.83-6.78 (m, 2H), 5.73 (dd, $1 \mathrm{H}, J=10.6,10.6 \mathrm{~Hz}), 5.51$ (ddd, 1H, $J=10.7,7.4,7.4 \mathrm{~Hz}), 4.77-4.63(\mathrm{~m}, 1 \mathrm{H}), 4.49(\mathrm{ABq}, 2 \mathrm{H}, J=16.2 \mathrm{~Hz}, \Delta v=33.2 \mathrm{~Hz}), 3.84(\mathrm{~s}, 3 \mathrm{H}), 3.75$ (s, $3 \mathrm{H}), 3.32(\mathrm{dd}, 1 \mathrm{H}, J=11.1,4.9 \mathrm{~Hz}), 3.29-3.17(\mathrm{~m}, 2 \mathrm{H}), 3.25(\mathrm{dd}, 1 \mathrm{H}, J=11.4,5.1 \mathrm{~Hz}), 2.87$ (ddd, $1 \mathrm{H}, J=5.3$, 5.3, $5.3 \mathrm{~Hz}), 2.36(\mathrm{~s}, 3 \mathrm{H}), 2.31-2.21(\mathrm{~m}, 1 \mathrm{H}), 2.13-2.04(\mathrm{~m}, 1 \mathrm{H}) \mathrm{ppm}$; IR (thin film) v 3339 (br), 3011, 2934, 1596, $1579,1513,1498,1256,1136,1080,833 \mathrm{~cm}^{-1}$; HRMS $\left(\mathrm{ES}^{+}\right)$calcd for $\mathrm{C}_{32} \mathrm{H}_{42} \mathrm{~N}_{6} \mathrm{O}_{8} \mathrm{~S}_{3} 734.2226$ found 757.2117 $\left(\mathrm{MNa}^{+}\right)$.

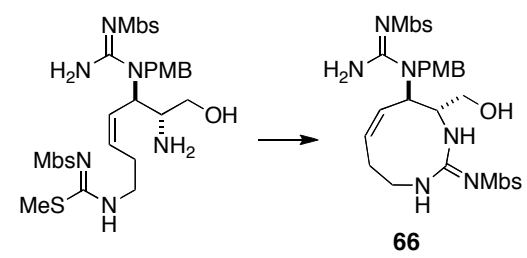

Amino alcohol (38 mg, $52 \mu \mathrm{mol})$ was dissolved in $6.0 \mathrm{~mL}$ of MeCN and added dropwise over $45 \mathrm{~min}$ to a solution of $\mathrm{AgNO}_{3}\left(11 \mathrm{mg}, 67 \mu \mathrm{mol}, 1.3\right.$ equiv) and $\mathrm{Et}_{3} \mathrm{~N}(72 \mu \mathrm{L}, 517 \mu \mathrm{mol}, 10$ equiv) in $10 \mathrm{~mL}$ of MeCN. Transfer of this material was made quantitative with $2 \times 0.5 \mathrm{~mL}$ of MeCN. The reaction flask was wrapped in aluminum foil and the contents stirred in the dark for $20 \mathrm{~min}$. The pale yellow suspension was then filtered through a small pad of Celite, rinsing the flask and filter cake with $40 \mathrm{~mL}$ of $\mathrm{CH}_{2} \mathrm{Cl}_{2}$. Concentration of the combined filtrates under reduced pressure gave an oily residue, which was purified by chromatography on silica gel $\left(93: 7 \mathrm{CH}_{2} \mathrm{Cl}_{2} / \mathrm{MeOH}\right)$ to give the desired 9-membered ring guandine 66 as a white foam $(26 \mathrm{mg}, 73 \%)$ : TLC $\mathrm{R}_{f}=0.38\left(93: 7 \mathrm{CH}_{2} \mathrm{Cl}_{2} / \mathrm{MeOH}\right) ;{ }^{1} \mathrm{H}$ $\operatorname{NMR}\left(\mathrm{CD}_{3} \mathrm{CN}, 400 \mathrm{MHz}, 70{ }^{\circ} \mathrm{C}\right) \delta$ 7.86-7.63 (m, 4H), 7.04-6.95 (m, 2H), 6.95-6.87 (m, 2H), 6.91 (br s, 2H), 6.87$6.78(\mathrm{~m}, 2 \mathrm{H}), 6.35$ (br s, 2H), 4.90-4.66 (m, 1H), 4.66-4.45 (m, 1H), 4.45-4.08 (m, 2H), $3.85(\mathrm{~s}, 3 \mathrm{H}), 3.78(\mathrm{~s}, 3 \mathrm{H})$, $3.72-3.50(\mathrm{~m}, 4 \mathrm{H}), 3.48-3.33(\mathrm{~m}, 2 \mathrm{H}) 2.22-1.50(\mathrm{~m}, 5 \mathrm{H}) \mathrm{ppm}$; IR (thin film) v 3336, 2930, 1596, 1515, 1498, 1258, $1134,1081,835,811 \mathrm{~cm}^{-1}$; HRMS (ES $\left.{ }^{+}\right)$calcd for $\mathrm{C}_{31} \mathrm{H}_{38} \mathrm{~N}_{6} \mathrm{O}_{8} \mathrm{~S}_{2} 686.2193$ found $709.2084\left(\mathrm{MNa}^{+}\right)$.

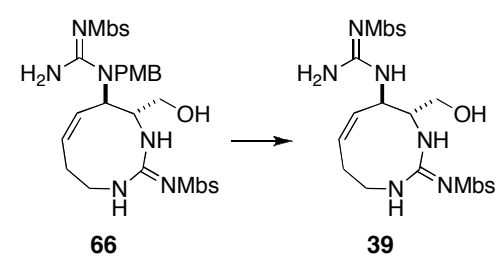

Cyclic guanidine $66(13 \mathrm{mg}, 19 \mu \mathrm{mol})$ was dissolved in $1.0 \mathrm{~mL}$ of TFA, the reaction vessel was sealed with a glass stopper, and the solution was stirred for $6 \mathrm{~h}$ at $60{ }^{\circ} \mathrm{C}$. After cooling to $23{ }^{\circ} \mathrm{C}$, the mixture was concentrated under reduced pressure to a solid residue. Purification by chromatography on silica gel $\left(93: 7 \mathrm{CH}_{2} \mathrm{Cl}_{2} / \mathrm{MeOH}\right)$ afforded alcohol 39 as a white solid (10 mg, 91\%): TLC $\mathrm{R}_{f}=0.28\left(20: 1 \mathrm{CH}_{2} \mathrm{Cl}_{2} / \mathrm{MeOH}\right) ;{ }^{1} \mathrm{H}$ NMR $\left(\mathrm{CD}_{3} \mathrm{CN}, 500 \mathrm{MHz}\right.$, $\left.70^{\circ} \mathrm{C}\right) \delta$ 7.78-7.68 (m, 4H), 7.03-6.92 (m, 4H), 6.67 (br s, 1H), 6.20 (br s, 2H), 5.71 (br s, 1H), 4.98 (br s, 1H), 4.85$4.73(\mathrm{~m}, 1 \mathrm{H}), 4.63(\mathrm{t}, 1 \mathrm{H}, J=10.0 \mathrm{~Hz}), 3.85(\mathrm{~s}, 3 \mathrm{H}), 3.84(\mathrm{~s}, 3 \mathrm{H}), 3.72(\mathrm{br} \mathrm{d}, 1 \mathrm{H}, J=11.0 \mathrm{~Hz}), 3.62(\mathrm{br} \mathrm{d}, 1 \mathrm{H}, J=$ $11.0 \mathrm{~Hz}$ ), 3.50-3.35 (m, 2H), 3.23 (br s, 1H), 2.44 (br s, 1H), 2.04-1.99 (br m, 1H) ppm. HRMS (ES ${ }^{+}$) calcd for $\mathrm{C}_{23} \mathrm{H}_{30} \mathrm{~N}_{6} \mathrm{O}_{7} \mathrm{~S}_{2} 566.1617$ found $589.1513\left(\mathrm{MNa}^{+}\right)$. 
HMBC Correlations for Synthetic (+)-STX $\bullet 2 \mathrm{C}_{3} \mathrm{~F}_{7} \mathrm{CO}_{2}^{-}\left(\mathrm{D}_{2} \mathrm{O}, 600 \mathrm{MHz}\right)$ :
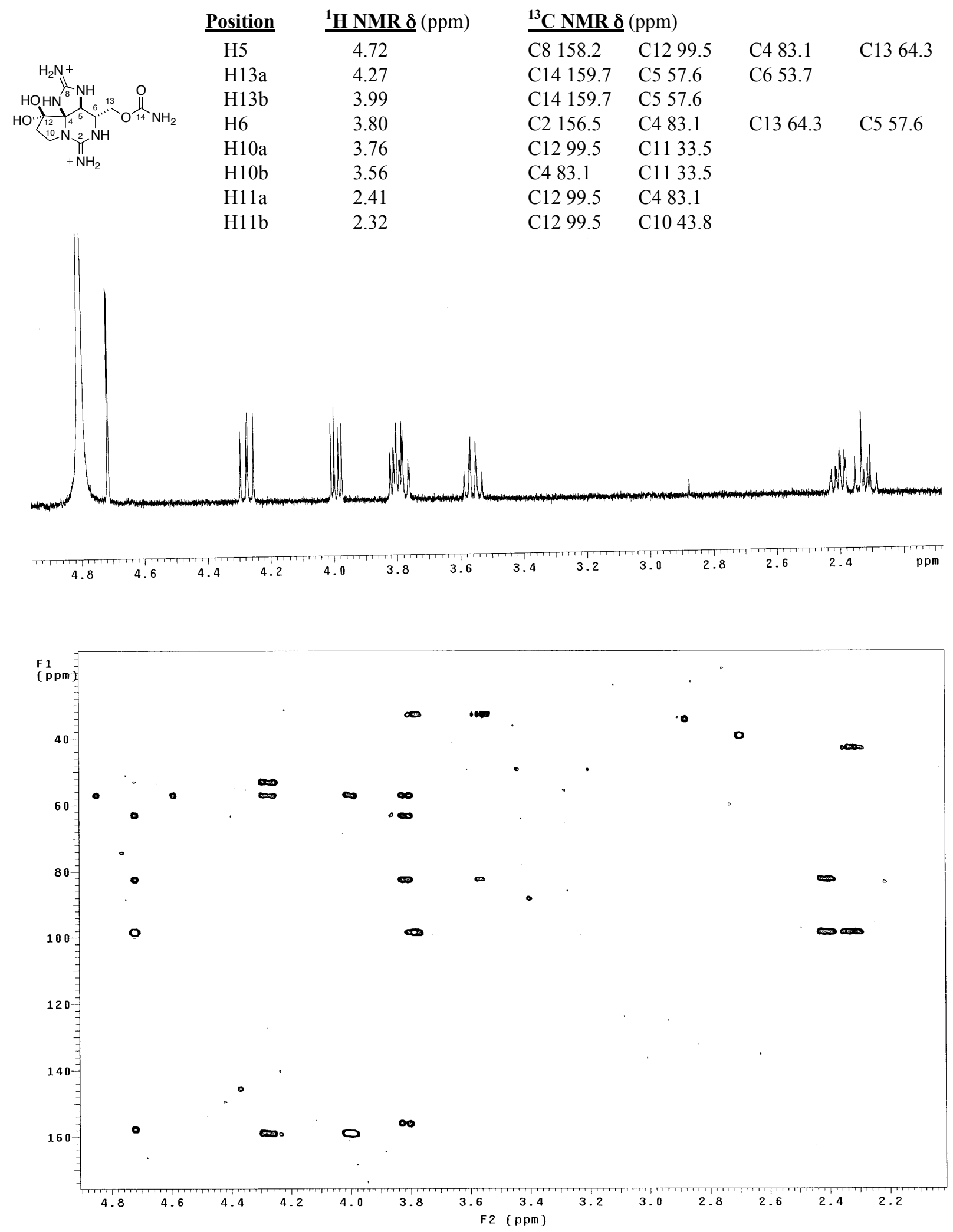
Comparison of Spectral Data for Synthetic and Natural (+)-Saxitoxin:

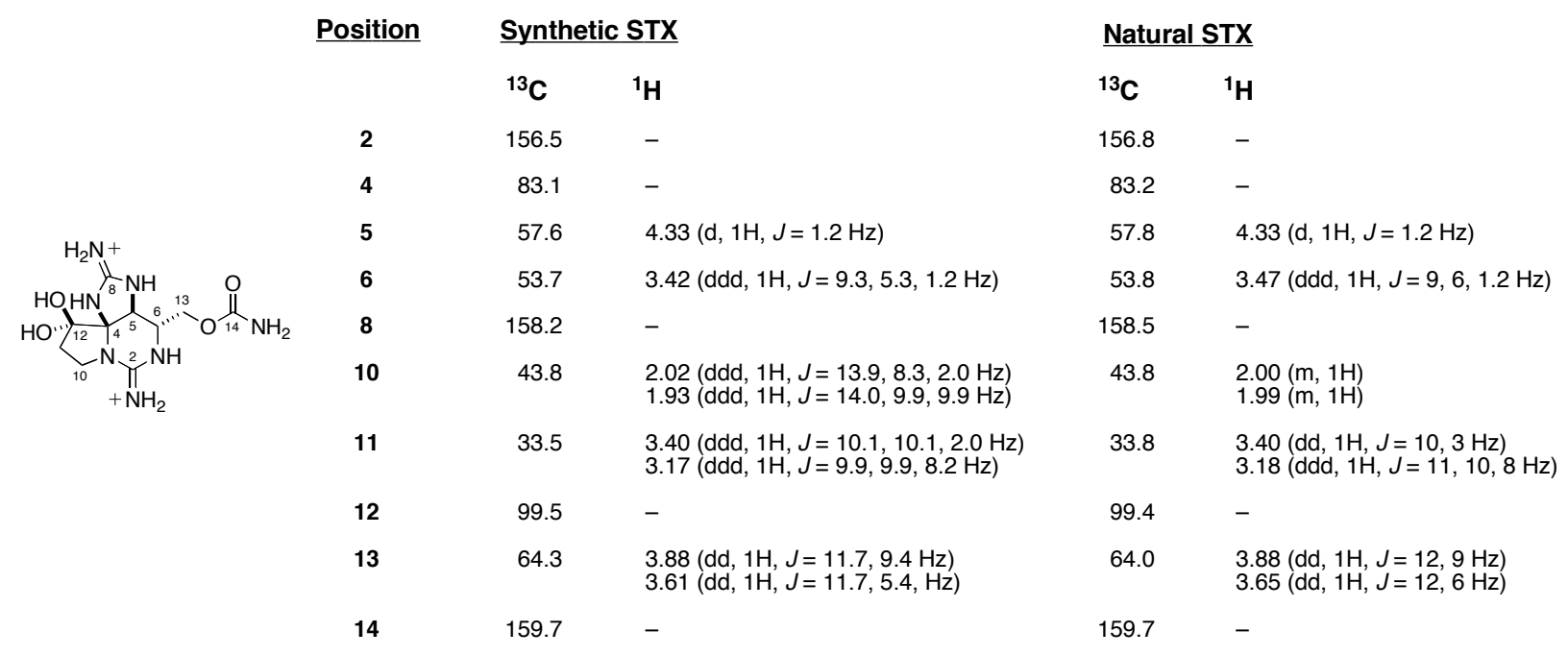

- $\quad{ }^{1} \mathrm{H}$ NMR of synthetic STX $\bullet 2 \mathrm{C}_{3} \mathrm{~F}_{7} \mathrm{CO}_{2}^{-}$was recorded in $\mathrm{D}_{2} \mathrm{O}$ and referenced internally to HOD at $\delta 4.40 \mathrm{ppm}$.

- ${ }^{13} \mathrm{C}$ NMR data for synthetic STX $2 \mathrm{C}_{3} \mathrm{~F}_{7} \mathrm{CO}_{2}{ }^{-}$was obtained by $\mathrm{HMBC}$ analysis.

- Data for natural STX was reported by Koehn et al. ${ }^{9}$

${ }^{1} \mathrm{H}$ NMR Spectrum of Natural STX (270 MHz, $\mathrm{D}_{2} \mathrm{O}$, HOD referenced at $\left.4.50 \mathrm{ppm}\right):^{13}$

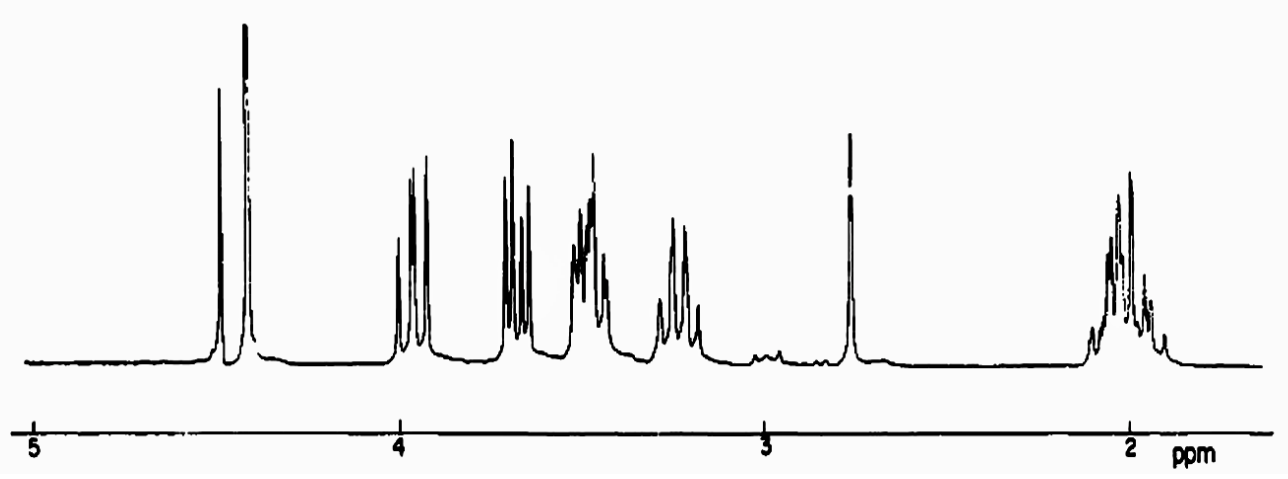

${ }^{1} \mathrm{H}$ NMR Spectrum of Synthetic STX (500 MHz, $\mathrm{D}_{2} \mathrm{O}$, HOD referenced at $\left.4.50 \mathrm{ppm}\right)$ :

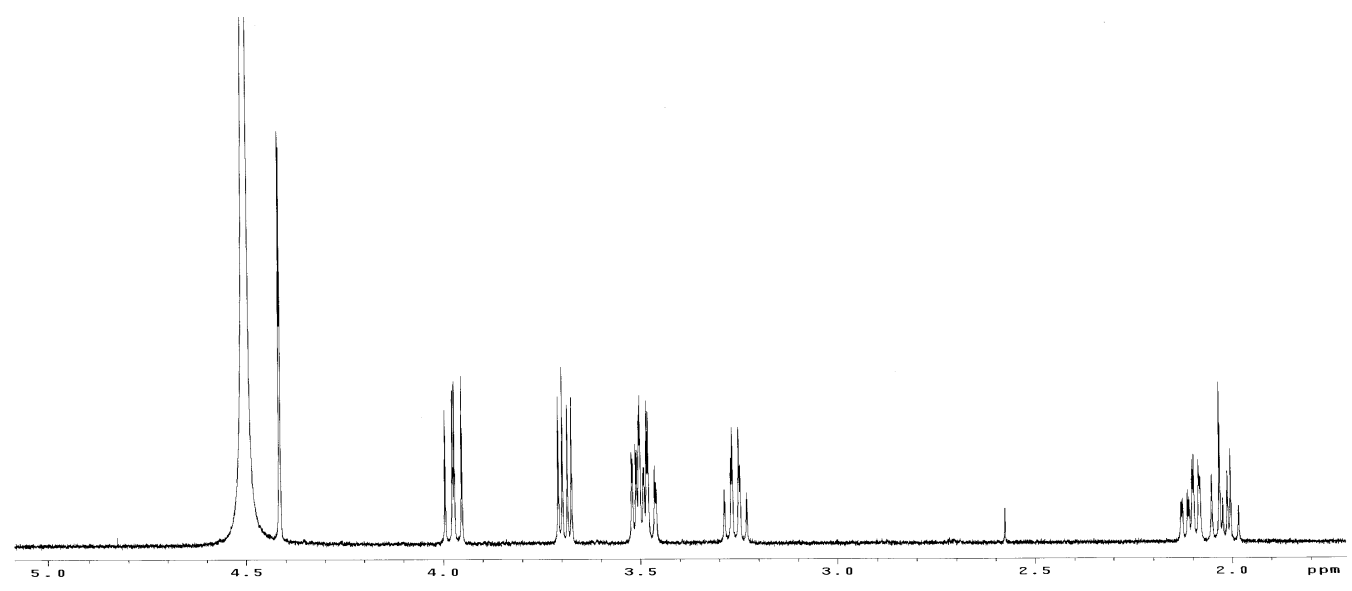


Table of Energies and Zero-Point Vibrational Corrections (ZPVE): ${ }^{14}$

$\begin{array}{crrrr}\text { isomer } & \text { E (hartree) } & \text { ZPVE (Hart) } & \text { E + ZPVE } & \text { E }_{\text {rel }}(\mathbf{k c a l} / \mathbf{m o l}) \\ \mathbf{1} & -2252.4936 & 0.411723 & -2252.0819 & 0 \\ \mathbf{2} & -2252.4845 & 0.411595 & -2252.0729 & 5.62060707 \\ \mathbf{3} & -2252.4669 & 0.409142 & -2252.0578 & 15.1160884 \\ \mathbf{4}^{*} & -2252.471 & 0.409498 & -2252.0615 & 12.7861438 \\ \mathbf{5} & -2252.4699 & 0.411153 & -2252.0587 & 14.523719 \\ \mathbf{6} & -2252.4696 & 0.411349 & -2252.0582 & 14.8381015 \\ \mathbf{7} & -2252.463 & 0.410564 & -2252.0524 & 18.4845621 \\ \mathbf{8}^{\text {** }} & -2252.4691 & 0.412534 & -2252.0566 & 15.8766305\end{array}$

* The minimized structure was found to be a second order saddle point on the energy surface and not a true local minimum. ** The minimized structure was found to be a first order saddle point on the energy surface and not a true local minimum.
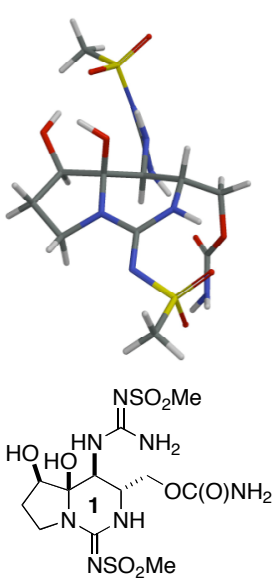

$\mathrm{E}_{\mathrm{rel}}=\mathbf{0}(\mathrm{kcal} / \mathrm{mol})$
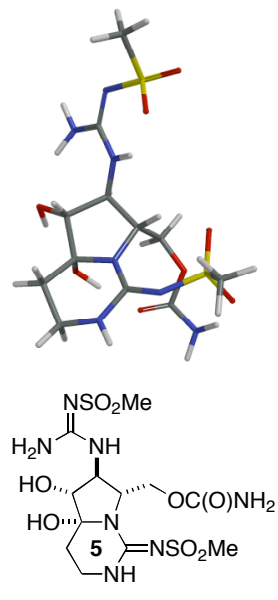

$E_{\text {rel }}=14.5(\mathrm{kcal} / \mathrm{mol})$
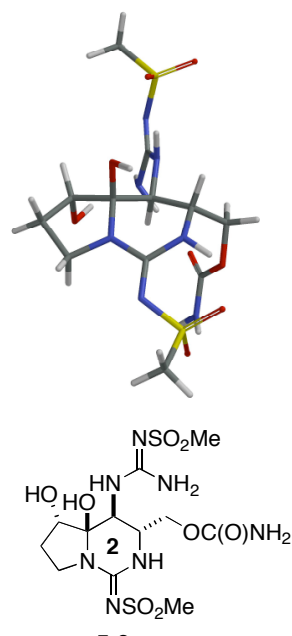

5.6
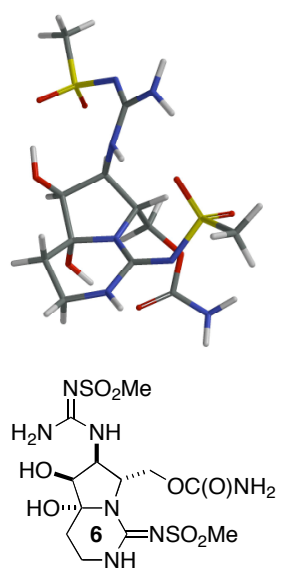

14.8
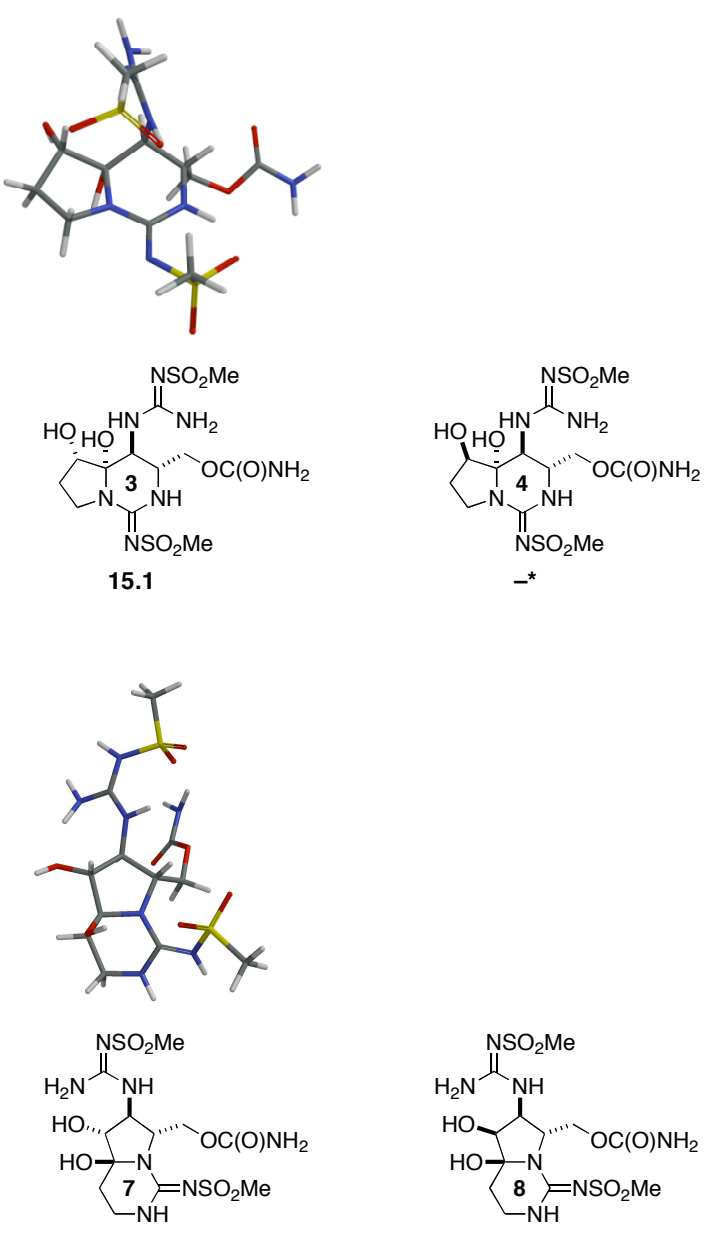

18.5

(1) Neidlein, R.; Haussman, W. Angew. Chem., Int. Ed. 1965, 4, 521-524.

(2) Gompper, R.; Kunz, R. Chem. Ber. 1966, 99, 2900-2904.

(3) Tanga, M. J.; Bradford, W. W.; Bupp, J. E.; Kozocas, J. A. J. Heterocyclic Chem. 2003, 40, 569-573. 
(4) Pless, J.; Bauer, W. Angew. Chem., Int. Ed. 1973, 12, 147-148.

(5) The corresponding amino acid was prepared following the method of Myers, see: Myers, A. G.; Gleason, J. L.; Yoon, T.; Kung, D. W. J. Am. Chem. Soc. 1997, 119, 656-673.

(6) Vogel's Textbook of practical organic chemistry; Vogel, A. I.; Furniss, B., 5th ed.; John Wiley \& Sons: New York, 1989; p 424.

(7) Koehn, F. E.; Schnoes, H. K.; Kao, C. Y. Biochim. Biophys. Acta 1983, 734, 129-132.

(8) ${ }^{13} \mathrm{C}$ NMR chemical shifts for $\beta$-STXol match those reported by Rapoport, see: Rogers, R. S.; Rapoport, H. J. Am. Chem. Soc. 1980, 102, 7335-7339.

(9) Koehn, F. E.; Ghazarossian, V. E.; Schantz, E. J.; Schnoes, H. K.; Strong, F. M. Bioorg. Chem. 1981, 10, $412-428$.

(10) The bis- $\mathrm{Cl}^{-}$salt of (+)-saxitoxin was prepared from the bis- $\left(\mathrm{C}_{3} \mathrm{~F}_{7} \mathrm{CO}_{2}^{-}\right)$adduct by azeotropic removal of $\mathrm{C}_{3} \mathrm{~F}_{7} \mathrm{CO}_{2} \mathrm{H}$ from $10 \mathrm{mM}$ aqueous $\mathrm{HCl}$ solutions. The material was concentrated under reduced pressure three times $(3 \times 5 \mathrm{~mL})$ to ensure the complete removal of $\mathrm{C}_{3} \mathrm{~F}_{7} \mathrm{CO}_{2} \mathrm{H}$, which was confirmed by ${ }^{19} \mathrm{~F}$ NMR.

(11) Schantz, E. J.; Mold, J. D.; Stanger, D. W.; Shavel, J.; Riel, F. J.; Bowden, J. P.; Lynch, J. M.; Wyler, R. S.; Riegel, B.; Sommer, H. J. Am. Chem. Soc. 1957, 79, 5230-5235.

(12) Nakano, Y.; Kato, Y.; Imai, K.; Ochiai, E.; Namekawa, J.-i.; Ishizuka, S.; Takenouchi, K.; Tanatani, A.; Hashimoto, Y.; Nagasawa, K. J. Med. Chem. 2006, 49, 2398-2406.

(13) Niccolai, N.; Schnoes, H. K.; Gibbons, W. A. J. Am. Chem. Soc. 1980, 102, 1513-1517.

(14) Gaussian 03, Revision C.02; M. J. Frisch, G. W. Trucks, H. B. Schlegel, G. E. Scuseria, M. A. Robb, J. R. Cheeseman, J. A. Montgomery, Jr., T. Vreven, K. N. Kudin, J. C. Burant, J. M. Millam, S. S. Iyengar, J. Tomasi, V. Barone, B. Mennucci, M. Cossi, G. Scalmani, N. Rega, G. A. Petersson, H. Nakatsuji, M. Hada, M. Ehara, K. Toyota, R. Fukuda, J. Hasegawa, M. Ishida, T. Nakajima, Y. Honda, O. Kitao, H. Nakai, M. Klene, X. Li, J. E. Knox, H. P. Hratchian, J. B. Cross, C. Adamo, J. Jaramillo, R. Gomperts, R. E. Stratmann, O. Yazyev, A. J. Austin, R. Cammi, C. Pomelli, J. W. Ochterski, P. Y. Ayala, K. Morokuma, G. A. Voth, P. Salvador, J. J. Dannenberg, V. G. Zakrzewski, S. Dapprich, A. D. Daniels, M. C. Strain, O. Farkas, D. K. Malick, A. D. Rabuck, K. Raghavachari, J. B. Foresman, J. V. Ortiz, Q. Cui, A. G. Baboul, S. Clifford, J. Cioslowski, B. B. Stefanov, G. Liu, A. Liashenko, P. Piskorz, I. Komaromi, R. L. Martin, D. J. Fox, T. Keith, M. A. Al-Laham, C. Y. Peng, A. Nanayakkara, M. Challacombe, P. M. W. Gill, B. Johnson, W. Chen, M. W. Wong, C. Gonzalez, and J. A. Pople; Gaussian, Inc., Wallingford CT, 2004. 